National Water-Quality Assessment Program

\title{
Effects of Agriculture and Urbanization on Quality of Shallow Ground Water in the Arid to Semiarid Western United States, 1993-2004
}

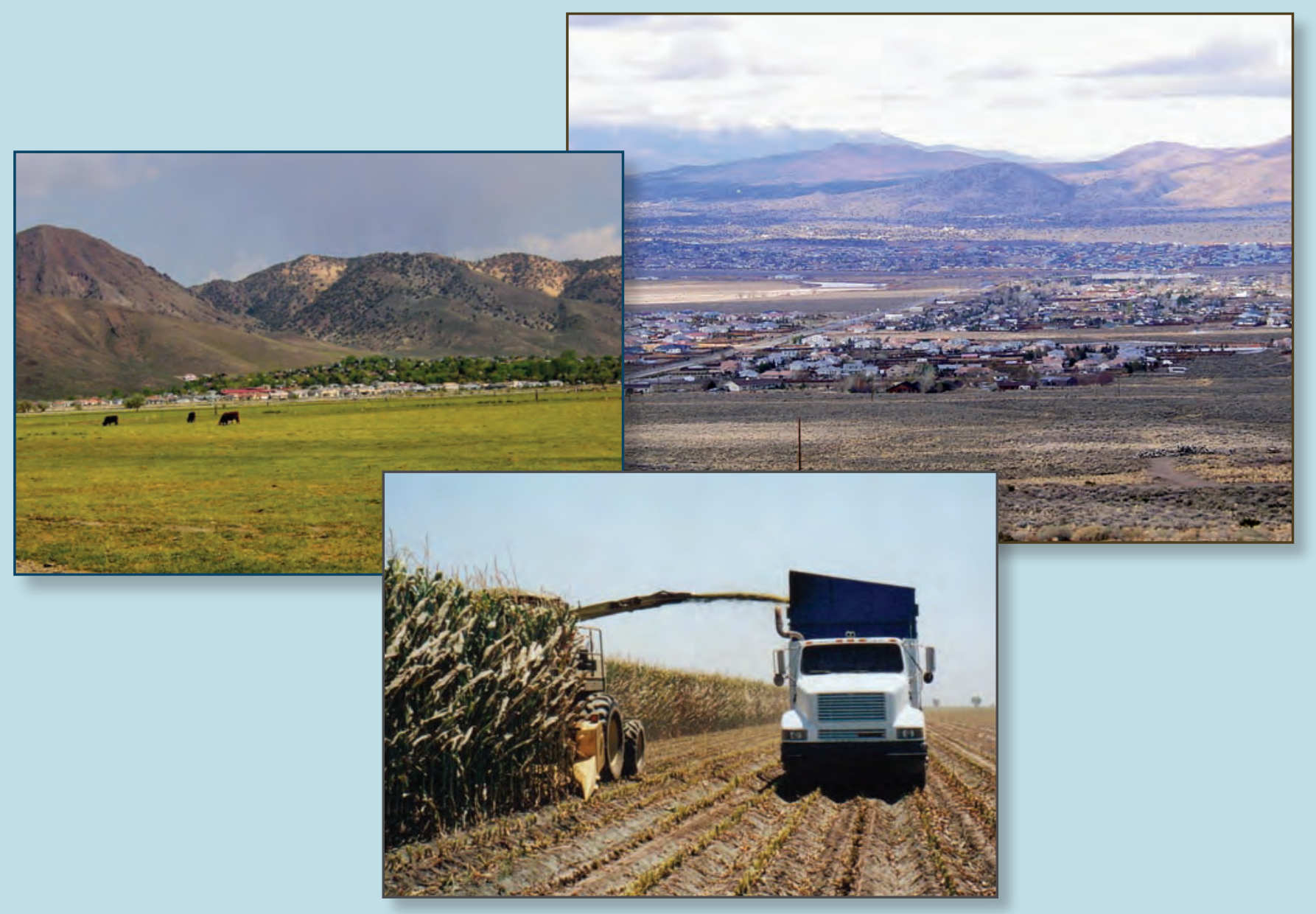

Scientific Investigations Report 2007-5179 
Cover: Photographs (clockwise from left) showing

1. Agricultural fields with encroaching urban area in background, Reno, Washoe County, Nevada.

(Photograph taken by Timothy G. Rowe, U.S. Geological Survey, Carson City, Nev., 2005.)

2. Spanish Springs, Washoe County, Nevada. (Photograph taken by Michael Rosen, U.S. Geological

Survey, Carson City, Nev., 2005.)

3. Silage corn harvesting in Tulare County, California. (Photograph taken by Jennifer L. Shelton, U.S.

Geological Survey, Sacramento, Calif., 2002.) 


\section{Effects of Agriculture and Urbanization on Quality of Shallow Ground Water in the Arid to Semiarid Western United States, 1993-2004}

By Angela P. Paul, Ralph L. Seiler, Timothy G. Rowe, and Michael R. Rosen

National Water-Quality Assessment Program

Scientific Investigations Report 2007-5179 


\title{
U.S. Department of the Interior DIRK KEMPTHORNE, Secretary
}

\author{
U.S. Geological Survey \\ Mark D. Myers, Director
}

\section{U.S. Geological Survey, Reston, Virginia: 2007}

For product and ordering information:

World Wide Web: http://www.usgs.gov/pubprod

Telephone: 1-888-ASK-USGS

For more information on the USGS--the Federal source for science about the Earth, its natural and living resources, natural hazards, and the environment:

World Wide Web: http://www.usgs.gov

Telephone: 1-888-ASK-USGS

Any use of trade, product, or firm names is for descriptive purposes only and does not imply endorsement by the U.S. Government.

Although this report is in the public domain, permission must be secured from the individual copyright owners to reproduce any copyrighted materials contained within this report.

Suggested citation:

Paul, A.P., Seiler, R.L., Rowe, T.G., and Rosen, M.R., 2007, Effects of agriculture and urbanization on quality of shallow ground water in the arid to semiarid western United States, 1993-2004: U.S. Geological Survey Scientific Investigations Report 2007-5179, 56 p. 


\section{Foreword}

The U.S. Geological Survey (USGS) is committed to providing the Nation with accurate and timely scientific information that helps enhance and protect the overall quality of life and that facilitates effective management of water, biological, energy, and mineral resources (http://www.usgs. gov/). Information on the quality of the Nation's water resources is critical to assuring the long-term availability of water that is safe for drinking and recreation and suitable for industry, irrigation, and habitat for fish and wildlife. Population growth and increasing demands for multiple water uses make water availability, now measured in terms of quantity and quality, even more essential to the long-term sustainability of our communities and ecosystems.

The USGS implemented the National Water-Quality Assessment (NAWQA) Program in 1991 to support national, regional, and local information needs and decisions related to water-quality management and policy (http://water.usgs.gov/nawqa). Shaped by and coordinated with ongoing efforts of other Federal, State, and local agencies, the NAWQA Program is designed to answer: What is the condition of our Nation's streams and ground water? How are the conditions changing over time? How do natural features and human activities affect the quality of streams and ground water, and where are those effects most pronounced? By combining information on water chemistry, physical characteristics, stream habitat, and aquatic life, the NAWQA Program aims to provide science-based insights for current and emerging water issues and priorities.

From 1991-2001, the NAWQA Program completed interdisciplinary assessments in 51 of the Nation's major river basins and aquifer systems, referred to as Study Units (http://water.usgs.gov/ nawqa/studyu.html). Baseline conditions were established for comparison to future assessments, and long-term monitoring was initiated in many of the basins. During the next decade, 42 of the 51 Study Units will be reassessed so that 10 years of comparable monitoring data will be available to determine trends at many of the Nation's streams and aquifers. The next 10 years of study also will fill in critical gaps in characterizing water-quality conditions, enhance understanding of factors that affect water quality, and establish links between sources of contaminants, the transport of those contaminants through the hydrologic system, and the potential effects of contaminants on humans and aquatic ecosystems.

The USGS aims to disseminate credible, timely, and relevant science information to inform practical and effective water-resource management and strategies that protect and restore water quality. We hope this NAWQA publication will provide you with insights and information to meet your needs, and will foster increased citizen awareness and involvement in the protection and restoration of our Nation's waters.

The USGS recognizes that a national assessment by a single program cannot address all waterresource issues of interest. External coordination at all levels is critical for a fully integrated understanding of watersheds and for cost-effective management, regulation, and conservation of our Nation's water resources. The NAWQA Program, therefore, depends on advice and information from other agencies_-Federal, State, interstate, Tribal, and local—as well as nongovernmental organizations, industry, academia, and other stakeholder groups. Your assistance and suggestions are greatly appreciated.

Robert M. Hirsch

Associate Director for Water 
This page is intentionally left blank. 


\section{Contents}

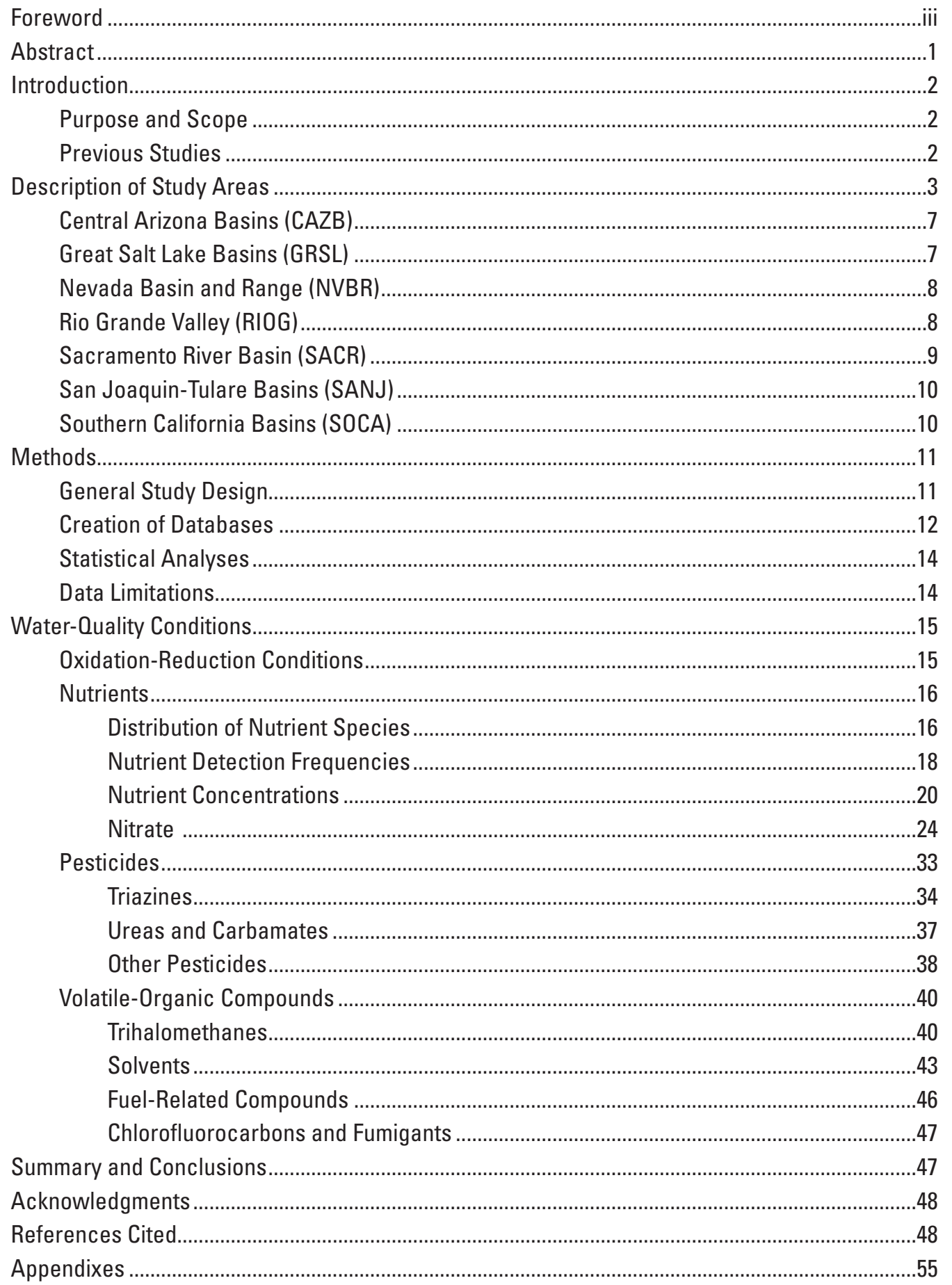




\section{Figures}

Figure 1. Map showing Location of regional National Water-Quality Assessment (NAWQA) Program study units in the arid to semiarid Western United States, 1993-2004

Figure 2. Map showing location of wells sampled in agricultural and urban areas within regional National Water-Quality Assessment (NAWQA) Program study units in the arid to semiarid Western United States, 1993-2004

Figure 3. Graph showing dissolved-oxygen concentration in ground water from agricultural and urban areas within regional National Water-Quality Assessment Program study units in the arid to semiarid Western United States, 1993-2004

Figure 4. Graph showing statistical relation of dissolved-oxygen concentration among regional National Water-Quality Assessment Program study units and respective land-use settings, in the arid to semiarid Western United States, 1993-2004

Figure 5. Graphs showing nutrient speciation in ground-water samples collected from agricultural and urban areas in regional National Water-Quality Assessment Program study units in the arid to semiarid Western United States, 1993-2004

Figure 6. Graphs showing percentage of nutrient detections following recensoring of nutrient datasets for entire dataset, and after removing replicate analyses, retaining only the most recent analysis at a given site, within regional National Water-Quality Assessment Program study units in the arid to semiarid Western United States, 1993-2004

Figure 7. Graphs showing effect of land use on the percentage of detections following recensoring of nutrient data sets for entire data set and after removing replicate analyses, retaining only the most recent analysis from a given site, within regional National Water-Quality Assessment Program study units in the arid to semiarid Western United States, 1993-2004

Figure 8. Graphs showing nutrient concentration in filtered ground-water samples collected from agricultural and urban areas within regional National Water-Quality Assessment Program study units in the arid to semiarid Western United States, 1993-2004

Figure 9. Graphs showing nutrient concentration in filtered ground-water samples collected from agricultural and urban areas within regional National Water-Quality Assessment Program study units in the arid to semiarid Western United States, 1993-2004

Figure 10. Graphs showing relation between land use and application of nitrogen fertilizer and households served by septic systems within regional National Water-Quality Assessment Program study units in the arid to semiarid Western United States, 1993-2004

Figure 11. Graphs showing nitrate concentration in water samples collected from all agricultural wells, agricultural wells in the San Joaquin-Tulare Basins (SANJ) study unit, and agricultural wells in the Central Arizona Basins (CAZB), Nevada Basin and Range (NVBR), Rio Grande Valley (RIOG), and Sacramento River Basin (SACR), 1993-2004

Figure 12. Graphs showing relation between median nitrate concentration with median fertilizer application rate and median dissolved-oxygen concentration in agricultural and urban areas in the Nevada Basin and Range (NVBR), Rio Grande Valley (RIOG), and Sacramento River Basin (SACR), 1993-2004 


\section{Figures-Continued}

Figure 13. Graphs showing relation between ranked nitrate concentrations and ranked well, aquifer, and land-use characteristics in agricultural areas within regional National Water-Quality Assessment Program study units in the arid to semiarid Western United States, 1993-2004 ....

Figure 14. Graphs showing relation between ranked nitrate concentrations and ranked well, aquifer, and land-use characteristics in urban areas within regional National Water-Quality Assessment Program study units in the arid to semiarid Western United States, 1993-2004

Figure 15. Graph showing relation between ranked nitrate concentrations and ranked nitrogen application rates in agricultural areas within in regional National Water-Quality Assessment Program study units in the arid to semiarid Western United States, 1993-2004

Figure 16. Graphs showing relation among iron, nitrite, and dissolved-oxygen concentrations in ground-water samples collected from agricultural areas within regional National Water-Quality Assessment Program study units in the arid to semiarid Western United States, 1993-2004.

Figure 17. Graph showing pesticide detection frequency in ground-water samples collected from agricultural and urban areas within regional National Water-Quality Assessment Program study units in the arid to semiarid Western United States, 1993-2004

Figure 18. Graph showing triazine herbicide detection frequency in ground-water samples collected from agricultural and urban areas within regional National Water-Quality Assessment Program study units in the arid to semiarid Western United States, 1993-2004

Figure 19. Graphs showing relation of atrazine and deethylatrazine (CIAT) detection frequencies in ground-water samples collected from urban and agricultural areas to percentage of agricultural and urban wells within each dissolved-oxygen category within regional National Water-Quality Assessment Program study units in the arid to semiarid Western United States, 1993-2004

Figure 20. Graph showing carbamate detection frequency in ground-water samples collected from agricultural and urban areas within regional National Water-Quality Assessment Program study units in the arid to semiarid Western United States, 1993-2004

Figure 21. Maps showing simazine pesticide use by county and township-and-range-scale coverages, and graphical comparison of pesticide-use scales in the San Joaquin-Tulare Basins (SANJ) study unit

Figure 22. Graph showing volatile-organic compound class detection frequency in ground-water samples collected from agricultural and urban areas within regional National Water-Quality Assessment Program study units in the arid to semiarid Western United States, 1993-2004

Figure 23. Graph showing trihalomethane detection frequency in samples collected from agricultural and urban areas within regional National Water-Quality Assessment Program study units in the arid to semiarid Western United States, 1993-2004 


\section{Figures-Continued}

Figure 24. Graphs showing relation of chloroform detection frequency in ground-water samples collected from urban and agricultural areas to percentage of agricultural and urban wells in each dissolved-oxygen category within regional National Water-Quality Assessment Program study units in the arid to semiarid Western United States, 1993-2004

Figure 25. Graph showing solvent detection frequency in water from wells sampled from agricultural and urban areas within regional National Water-Quality Assessment Program study units in the arid to semiarid Western United States, 1993-2004

Figure 26. Graphs showing relation of solvent detection frequencies in ground-water samples collected from urban and agricultural areas to dissolved-oxygen concentration within regional National Water-Quality Assessment Program study units in the arid to semiarid Western United States, 1993-2004

Figure 27. Graphs showing relation of methyl tert-butyl ether (MTBE) detection frequency collected from urban and agricultural areas to dissolved-oxygen concentration within regional National Water-Quality Assessment Program study units in the arid to semiarid Western United States, 1993-2004 46

\section{Tables}

Table 1. Average annual temperature, average annual precipitation, and estimated evaporation rates for regional National Water-Quality Assessment Program study units in the arid to semiarid Western United States, 1993-2004

Table 2. General aquifer characteristics, ground-water type, and water-quality data for ground-water samples collected from regional National Water-Quality Assessment Program study units in the arid to semiarid Western United States, 1993-2004

Table 3. Long-term method detection and censoring limits used during data analyses for this regional study

Table 4. Median values for selected well, aquifer, and land-use characteristics for regional National Water-Quality Assessment Program study units in the arid to semiarid Western United States, 1993-2004

Table 5. Median concentration of nutrient species within regional National Water-Quality Assessment Program study units in the arid to semiarid Western United States, 1993-2004

Table 6. Reactions sensitive to oxidation-reduction conditions that may influence nutrient concentrations in ground water

Table 7. Nitrate occurrence in shallow ground water beneath agricultural and urban areas within regional National Water-Quality Assessment Program study units in the arid to semiarid Western United States, 1993-2004

Table 8. Pesticide occurrence in shallow ground water beneath agricultural and urban areas within regional National Water-Quality Assessment Program study units in the arid to semiarid Western United States, 1993-2004

Table 9. Volatile-organic compound occurrence in shallow ground water beneath agricultural and urban areas within regional National Water-Quality Assessment Program study units in the arid to semiarid Western United States, 1993-2004 


\section{Conversion Factors, Datums, and Abbreviations}

Conversion Factors

\begin{tabular}{|c|c|c|}
\hline Multiply & By & To obtain \\
\hline \multicolumn{3}{|c|}{ Length } \\
\hline foot $(\mathrm{ft})$ & 0.3048 & meter $(\mathrm{m})$ \\
\hline mile (mi) & 1.609 & kilometer $(\mathrm{km})$ \\
\hline \multicolumn{3}{|c|}{ Area } \\
\hline acre & 0.004047 & square kilometer $\left(\mathrm{km}^{2}\right)$ \\
\hline square mile $\left(\mathrm{mi}^{2}\right)$ & 2.590 & square kilometer $\left(\mathrm{km}^{2}\right)$ \\
\hline square meter $\left(\mathrm{m}^{2}\right)$ & 10.765 & square foot $\left(\mathrm{ft}^{2}\right)$ \\
\hline \multicolumn{3}{|c|}{ Volume } \\
\hline acre-foot (acre-ft) & 1,233 & cubic meter $\left(\mathrm{m}^{3}\right)$ \\
\hline acre-foot (acre-ft) & 0.001233 & cubic hectometer $\left(\mathrm{hm}^{3}\right)$ \\
\hline \multicolumn{3}{|c|}{ Weight } \\
\hline pound (lb) & 0.454 & kilogram $(\mathrm{kg})$ \\
\hline \multicolumn{3}{|c|}{ Flow rate } \\
\hline acre-foot per day (acre-ft/d) & 0.01427 & cubic meter per second $\left(\mathrm{m}^{3} / \mathrm{s}\right)$ \\
\hline inch per year (in/yr) & 25.4 & millimeter per year $(\mathrm{mm} / \mathrm{yr})$ \\
\hline \multicolumn{3}{|c|}{ Application rate } \\
\hline pound per acre (lb/acre) & 0.112 & kilogram per squared kilometer $\left(\mathrm{kg} / \mathrm{km}^{2}\right)$ \\
\hline
\end{tabular}

Temperature in degrees Celsius $\left({ }^{\circ} \mathrm{C}\right)$ may be converted to degrees Fahrenheit $\left({ }^{\circ} \mathrm{F}\right)$ as follows:

$$
{ }^{\circ} \mathrm{F}=\left(1.8 x^{\circ} \mathrm{C}\right)+32 .
$$

Temperature in degrees Fahrenheit $\left({ }^{\circ} \mathrm{F}\right)$ may be converted to degrees Celsius $\left({ }^{\circ} \mathrm{C}\right)$ as follows:

$$
{ }^{\circ} \mathrm{C}=\left({ }^{\circ} \mathrm{F}-32\right) / 1.8 \text {. }
$$

Specific conductance is reported in microsiemens per centimeter at 25 degrees Celsius $\left(\mu \mathrm{S} / \mathrm{cm}\right.$ at $\left.25^{\circ} \mathrm{C}\right)$.

Concentrations of chemical constituents in water are reported either in milligrams per liter (mg/L) or micrograms per liter ( $\mu \mathrm{g} / \mathrm{L})$.

\section{Datums}

Vertical coordinate information is referenced to the North American Vertical Datum of 1988 (NAVD 88).

Horizontal coordinate information is referenced to the North American Datum of 1983 (NAD 83). Altitude, as used in this report, refers to distance above the vertical datum. 


\section{Conversion Factors, Datums, and Abbreviations-Continued}

\begin{tabular}{ll} 
Abbreviations & \\
\hline Abbreviation & \\
\hline BTEX & Benzene, Toluene, Ethylbenzene, Xylene \\
CAZB & Central Arizona Basins \\
CFC & Chlorofluorocarbons \\
DBCP & Dibromochloropropane \\
DIPE & Di-isopropyl ether \\
DO & Dissolved oxygen \\
ETBE & Ethyl tert-butyl ether \\
GRSL & Great Salt Lake Basins \\
LRL & laboratory reporting limit \\
LT-MDL & long-term method detection level \\
MCL & maximum contaminant level \\
MTBE & Methyl tert-butyl ether \\
NAWQA & National Water-Quality Assessment Program \\
NLCD & National Land Coverage Dataset \\
NLCDE & Enhanced National Land Coverage Dataset \\
NVBR & Nevada Basin and Range \\
NWIS & National Water Information System \\
NWQL & National Water Quality Laboratory \\
PCE & Tetrachloroethene \\
RCRA & Resource Conservation and Recovery Act \\
RIOG & Rio Grande Valley \\
SACR & Sacramento River Basin \\
SANJ & San Joaquin-Tulare Basins \\
SOCA & Southern California Basins \\
TAME & Tert-amyl methyl ether \\
TCE & Trichloroethene \\
THM & Trihalomethane \\
USEPA & U.S. Environmental Protection Agency \\
USGS & U.S. Geological Survey \\
VOC & volatile organic compound \\
\hline
\end{tabular}




\title{
Effects of Agriculture and Urbanization on Quality of Shallow Ground Water in the Arid to Semiarid Western United States, 1993-2004
}

\author{
By Angela P. Paul, Ralph L. Seiler, Timothy G. Rowe, and Michael R. Rosen
}

\section{Abstract}

Within the Western United States, agricultural and rural lands are being developed into commercial and residential areas. With changes in land use and increasing population, greater demands are placed on water resources for agricultural, industrial, and domestic supplies. Many areas in the Western United States rely exclusively on ground water as their source of drinking water. Areas that use surface-water resources often need to supplement this supply with ground water.

Generally, shallow ground water is susceptible to fluctuating water quality within relatively short time scales and therefore can be used as an indicator of land-use stresses that may, in time, affect deep aquifer systems. This regional study examines data on shallow ground-water quality collected from 1993 to 2004 from 273 agricultural and 181 urban wells from 7 U.S. Geological Survey National Water-Quality Assessment study units in Arizona, California, Nevada, New Mexico, south-central Colorado, and Utah. This report determines important influences that land-use practices may have on the quality of recently recharged ground water, which may ultimately affect deep water supplies within the region.

The results of this investigation show that nitrate, the principal species of nitrogen present in ground water, exceeds the U.S. Environmental Protection Agency (USEPA) maximum contaminant level (MCL) of 10 milligrams per liter in water from more than 25 percent of agricultural wells and 10 percent of urban wells. In agricultural areas, the probability of exceeding the USEPA MCL for nitrate is influenced primarily by three factors: fertilizer use, irrigation, and aquifer oxidation-reduction (redox) conditions. At the study-unit level, differences in nutrient concentrations between agricultural and urban land use likely are influenced by ground-water redox conditions within respective aquifer systems.

The most commonly detected pesticides belonged to the triazine, urea, amide, and carbamate classes. The triazine herbicides were the predominant pesticides present in both agricultural and urban areas. Simazine and diuron were most frequently detected in shallow ground water within agricultural areas, whereas atrazine, prometon, and tebuthiruon were more commonly detected in urban areas. The carbamate pesticides and the amide, metolachlor, were infrequently detected. Pesticide concentrations in shallow ground water within agricultural or urban land-use settings did not exceed established USEPA MCLs for drinking water. Generally, factors that influenced the detection of pesticides in shallow ground water in the regional area were dissolved oxygen, general soil permeability characteristics, temperature, and depth to screened interval.

The most commonly detected volatile organic compounds (VOCs) within urban areas were the trihalomethanes (THMs), solvents, and the fuel oxygenate, methyl tert-butyl-ether (MTBE). The most frequently detected THM was chloroform and the primary detected solvents were tetrachloroethene (PCE) and trichloroethene (TCE). Soil fumigants were detected almost entirely within an agricultural area in the Central Valley of California. The predominant fumigant detected was dibromochloropropane (DBCP), and its occurrence may be a result of its persistence and past use as a soil fumigant. THM concentrations did not exceed the USEPA MCL of 80 micrograms per liter $(\mu \mathrm{g} / \mathrm{L}$ ) for total THMs in any sample. Two ground-water samples collected within urban areas in Nevada exceeded the USEPA MCL for TCE $(5 \mu \mathrm{g} / \mathrm{L})$ and the drinking-water advisory for MTBE $(20-40 \mu \mathrm{g} / \mathrm{L})$. The PCE concentration in one sample from the urban area in Utah and five samples from urban areas within Nevada exceeded the $5 \mu \mathrm{g} / \mathrm{L} \mathrm{MCL}$. An important factor affecting the detection frequencies of VOCs was the ground-water redox condition. Chloroform and PCE were detected more frequently in well-oxygenated ground water, whereas MTBE was detected more frequently in less-oxygenated water. Multivariate logistic-regression showed that dissolved oxygen, $\mathrm{pH}$, and the percentage of industrial land use played important roles in the detection frequency of a number of VOCs present in groundwater samples. 


\section{Introduction}

Urbanization in the Western United States is occurring rapidly with projected population growth of about 46 percent between 2000 and 2030 (U.S. Census Bureau, 2005). The greatest increase in population (45.8 percent) is expected to occur in the Western United States compared to other regions in the United States, with an additional 29 million people expected during this period (U.S. Census Bureau, 2005). Nevada and Arizona are expected to undergo the greatest population growth in the country, with estimated growth rates of 114 and 109 percent, respectively. Throughout the country, land is being converted from pastures, agricultural fields, forests, and desert to commercial and residential communities. With increasing population and changing land use, demand for water resources will increase for use in agriculture (including irrigation, grazing, and stock watering), industry, and domestic supply.

In most ground-water basins, the quality of shallow ground water is influenced over relatively short time scales by near-surface activities and, therefore, can be used as an indicator of land-use stresses on shallow aquifers (Barbash and Resek, 2000). Although shallow aquifers are not typically used as municipal drinking-water supplies, concern arises where these shallow systems may be hydrologically linked to deep aquifers which are, or could be, used as sources of potable water. National studies have indicated that nonpoint chemical contamination of ground water in urban and agricultural landuse settings is occurring (Miller and Hamilton, 2001).

Natural factors that influence general ground-water quality include evapotranspiration and water-rock reactions. Although considerable variability existed among areas sampled, Walvoord and others (2003) determined that substantial subsoil nitrate reserves are present in desert environments. These reserves may pose a threat to groundwater resources through leaching of nitrate through the vadose zone (Walvoord and others, 2003). Numerous human factors affect ground-water quality, including infiltration of agricultural and urban irrigation water, irrigation with reclaimed wastewater, application of pesticides and fertilizers, artificial recharge, mining activities, leakage from septic tanks and sewer systems, and spills of chemicals during household, commercial, and industrial use. As a consequence of the increasing use of ground water in urban areas for drinking water and lawn irrigation, ground-water systems have become increasingly engineered through human activities such as artificial-recharge operations (Edmonds and Gellenbeck, 2002; Thiros and Manning, 2004; Hamlin and others, 2005).

Squillace and others (1999) estimated that untreated ground water in approximately 15 percent of the contiguous United States contains volatile organic compounds (VOCs) and that untreated ground water in urban areas was four times more likely to exceed a drinking-water criterion than untreated ground water in rural areas (Squillace and others, 1999). In agricultural and urban areas throughout the United States, about 15 percent of shallow ground water samples exceeded the U.S. Environmental Protection Agency (USEPA) drinking water standard for nitrate concentrations (U.S. Environmental Protection Agency, 2006) and moderate to high levels of herbicide contamination were detected in the samples (U.S. Geological Survey, 1999).

Since 1991, the National Water-Quality Assessment (NAWQA) program of the U.S. Geological Survey (USGS) has determined water-quality status and trends in major aquifer systems throughout the United States (Gilliom and others, 1995). Pilot efforts were undertaken as early as 1986 in some areas in the United States (Hirsch and others, 1988). Part of the NAWQA sampling effort included sampling of shallow aquifers in Arizona, California, Colorado, Nevada, New Mexico, and Utah. These shallow aquifers were included in this study because they are primarily alluvial aquifers and represent major metropolitan and agricultural areas of the southwestern United States. Water-quality data used in this study were collected to assess the effects of primary land use and hydrologic conditions on the concentration and distribution of anthropogenic compounds in shallow ground water within individual NAWQA study units (Gilliom and others 1995).

\section{Purpose and Scope}

The objective of this investigation was to evaluate the effect(s) of agricultural and urban land uses on shallow ground-water quality in the arid to semiarid Western United States. Ground-water-quality data collected from 1993 to 2004 from 273 agricultural and 181 urban wells in Arizona, California, Colorado, Nevada, New Mexico, and Utah were used. This report summarizes water-quality data for nutrients, pesticides and their degradation products, and VOCs. Potential explanatory factors influencing shallow ground-water quality such as aquifer oxidation-reduction (redox) condition, land use, general soil characteristics, and irrigation practices are identified.

\section{Previous Studies}

Shallow aquifers unaffected by human activities typically contain less than $2 \mathrm{mg} / \mathrm{L}$ nitrate (Mueller and Helsel, 1996; Edmonds and Gellenbeck, 2002), but can contain much higher concentrations. The occurrence of elevated nitrate concentrations in shallow ground water is 
caused by population density, surficial geology, depth to water, and ground-water chemistry (Nolan, 2001; Eckhardt and Stackelberg, 1995; Tesoriero and Voss, 1997). In the Western United States, the use of commercial fertilizers was determined to be the predominant source of nitrogen in agricultural areas (Puckett, 1994) and, in some cases, in urban areas (Hamlin and others, 2002). Seepage of irrigation drainage containing anthropogenic nitrate to ground water has been identified as an important source of nutrients in agricultural areas (Edmonds and Gellenbeck, 2002, p. 9). In forested watersheds and remote headwater areas with no apparent anthropogenic sources of nitrogen, atmospheric deposition was determined to be the dominant source of nitrogen (Puckett 1994). Secondary recharge from septic systems and lawn irrigation has been shown to elevate nitrate concentrations in urban areas (Thiros, 2003a; Shipley and Rosen, 2005; Maurer and Thodal, 2000).

Between 1992 and 2001, approximately one billion pounds of pesticides were used annually within the United States. It was estimated that in 2001, approximately 76 percent of registered pesticide use was for agricultural purposes (Gilliom and others, 2006). Pesticides frequently were detected in shallow ground-water samples from both agricultural and urban areas. Fumigants were more commonly detected in agricultural areas, insecticides were more common in urbanized areas, and herbicides were detected in both (Kolpin and others, 2000). NAWQA ground-water investigations determined that at least one or more detection of a pesticide or pesticide degradate were present in more than 50 percent of shallow and 33 percent of deep aquifers in areas with mixed land uses (Gilliom and others, 2006). Nationally, human-health based benchmarks established for pesticides were exceeded in about 5 percent of shallow ground-water samples from urban areas and 1 percent of ground-water samples from agricultural areas (Gilliom and others, 2006).

In samples of ambient ground water in the United States collected between 1985 and 1995, VOCs were detected more frequently in ground water collected from urban areas than rural areas (Squillace and others 1999). The VOCs most commonly detected in ground-water samples from urban areas were chloroform, methyl tert-butyl ether (MTBE), tetrachloroethene (PCE), and trichloroethene (TCE).

Dissolved-oxygen concentration, source of ground-water recharge, and type of land use were the most important factors associated with the distribution of VOCs in shallow ground water in newly developed urban areas (Squillace and others, 2004; Hamlin and others, 2002). Other studies determined well depth, depth-to-screened interval, and population density also to be important explanatory variables affecting the detection of VOCs (Shelton, 2005; Hamlin and others, 2002; Squillace and others, 1999).

\section{Description of Study Areas}

The NAWQA program focuses sampling efforts into geographically defined areas called "study units." A study unit covers about $3,850 \mathrm{mi}^{2}$ or more and is based on its groundand surface-water features (Gilliom and others, 1995). Data collected as part of nationally designed NAWQA land-use studies from seven study units (fig. 1) were used in this investigation: Central Arizona Basins (CAZB), Great Salt Lake Basins (GRSL), Nevada Basin and Range (NVBR), Rio Grande Valley (RIOG), Sacramento River Basin (SACR), San Joaquin-Tulare Basins (SANJ), and Southern California Basins (SOCA). These areas generally are classified as arid to semiarid, with average annual temperatures ranging from 23 to $86^{\circ} \mathrm{F}$, precipitation ranging from 4.5 to $17.9 \mathrm{in} / \mathrm{yr}$, and estimated evaporation rates ranging from 50 to $110 \mathrm{in} / \mathrm{yr}$ (table 1). Although there is some variability, ground water within the regional area typically is a calcium-bicarbonate type likely derived from the aquifer materials through which the waters flow (table 2). Median alkalinity among the study units ranges from 171 to $495 \mathrm{mg} / \mathrm{L}$ as calcium carbonate. Median specific-conductance values within the study units ranged from 503 to $5,140 \mu \mathrm{S} / \mathrm{cm}$. The range in median $\mathrm{pH}$ is relatively small and circumneutral (7.0 to 7.5). The number of wells sampled varied among study units, ranging from 9 to 110, with median well depths ranging from 20 to $129 \mathrm{ft}$ below land surface (table 2). The general location of wells sampled in each study unit is shown in figure 2.

Table 1. Average annual temperature, average annual precipitation, and estimated evaporation rates for regional National Water-Quality Assessment Program study units in the arid to semiarid Western United States, 1993-2004.

[See figure 1 for location of study units. Average annual temperature and precipitation: National Oceanic and Atmospheric Agency (NOAA), 2006; temperature to the nearest degree; precipitation to nearest tenth of an inch. Estimated evaporation rates: Kohler and others, 1959; Class A Pan evaporation. Abbreviation: ${ }^{\circ} \mathrm{F}$, degrees Fahrenheit]

\begin{tabular}{lcrc}
\hline \multicolumn{1}{c}{ Study unit } & $\begin{array}{c}\text { Average } \\
\text { annual } \\
\text { temperature } \\
\text { range } \\
\text { ('F) }\end{array}$ & $\begin{array}{c}\text { Average } \\
\text { annual } \\
\text { precipitation } \\
\text { (inches) }\end{array}$ & $\begin{array}{c}\text { Estimated } \\
\text { evaporation } \\
\text { rates } \\
\text { (inches } \\
\text { per year) }\end{array}$ \\
\hline Central Arizona Basins & $62-86$ & 8.3 & $80-105$ \\
Great Salt Lake Basins & $41-63$ & 16.5 & $50-60$ \\
Nevada Basin and Range & $35-80$ & $4.5-7.5$ & $65-110$ \\
Rio Grande Valley & $23-70$ & $7.2-9.5$ & $50-105$ \\
Sacramento River Basin & $48-74$ & 17.9 & $65-75$ \\
San Joaquin-Tulare Basins & $49-77$ & $6.5-13.8$ & $65-90$ \\
Southern California Basins & $58-71$ & 10.8 & $60-70$ \\
\hline
\end{tabular}




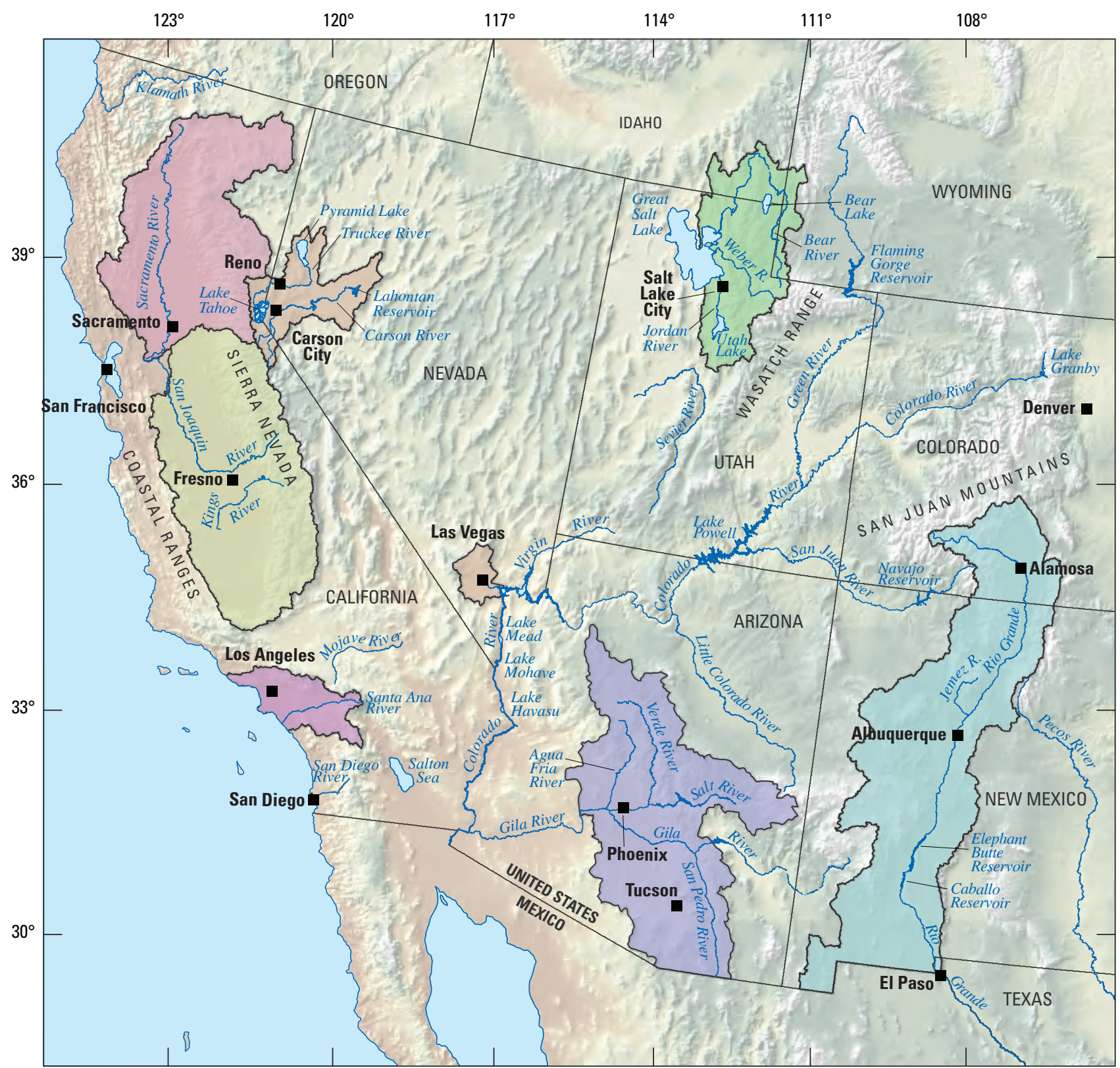

Base from U.S. Geological Survey digital data, 1:24,000-scale, 2005 and Tele Atlas/Geographic Data Technology digital data,

1:100,000-scale, 2005 Albers Equal Area Conic projection: Standard parallells $29^{\circ} 30^{\prime}, 45^{\circ} 30^{\prime}$, central meridian $96^{\circ}$, latitude of origin $23^{\circ}$, North American Datum of 1983 Shaded-relief base from Globe Elevation Data, 1:2,500,000. 2005; sun-illumination from northwest at 30 degrees above horizon

\section{EXPLANATION}

NAWOA Study Unit

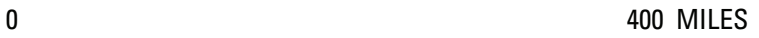

400 MILES

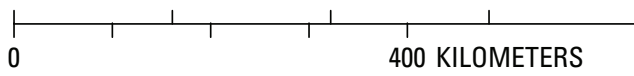

Central Arizona Basins (CAZB)

Great Salt Lake Basins (GRSL)

Nevada Basin and Range (NVBR)

Rio Grande Valley (RIOG)

Sacramento River Basin (SACR)

San Joaquin-Tulare Basins (SANJ)

Southern California Basins (SOCA)

Figure 1. Location of regional National Water-Quality Assessment (NAWQA) Program study units in the arid to semiarid Western United States, 1993-2004. 
Table 2. General aquifer characteristics, ground-water type, and water-quality data for ground-water samples collected from regional National Water-Quality Assessment Program study units in the arid to semiarid Western United States, 1993-2004.

[Predominant land use: determined within the 500-meter buffer zone around the wells used from each of the respective study units. Aquifer material: Page, 1986; Anderholm, 1996; Covay and others, 1996; Anderholm, 1997; Anderholm, 2002; Edmonds and Gellenbeck, 2002; Thiros, 2003b; Hamlin and others, 2002; and Scott Anderholm, U.S. Geological Survey, oral commun., 2007. Abbreviations: CAZB, Central Arizona Basins; GRSL, Great Salt Lake Basins; NVBR, Nevada Basin and Range; RIOG, Rio Grande Valley; SACR, Sacramento River Basin; SANJ, San Joaquin-Tulare Basins; SOCA, Southern California Basins; $\mathrm{Ca}$, calcium; $\mathrm{CaCO}_{3}$, calcium carbonate; $\mathrm{Cl}$, chloride; $\mathrm{Na}$, sodium; $\mathrm{HCO}_{3}$, bicarbonate; $\mathrm{Mg}$, magnesium; $\mathrm{SO}_{4}$, sulfate; $\mu \mathrm{S} / \mathrm{cm}$, microseimens per centimeter; $\mathrm{mg} / \mathrm{L}$, milligram per liter; ft, foot]

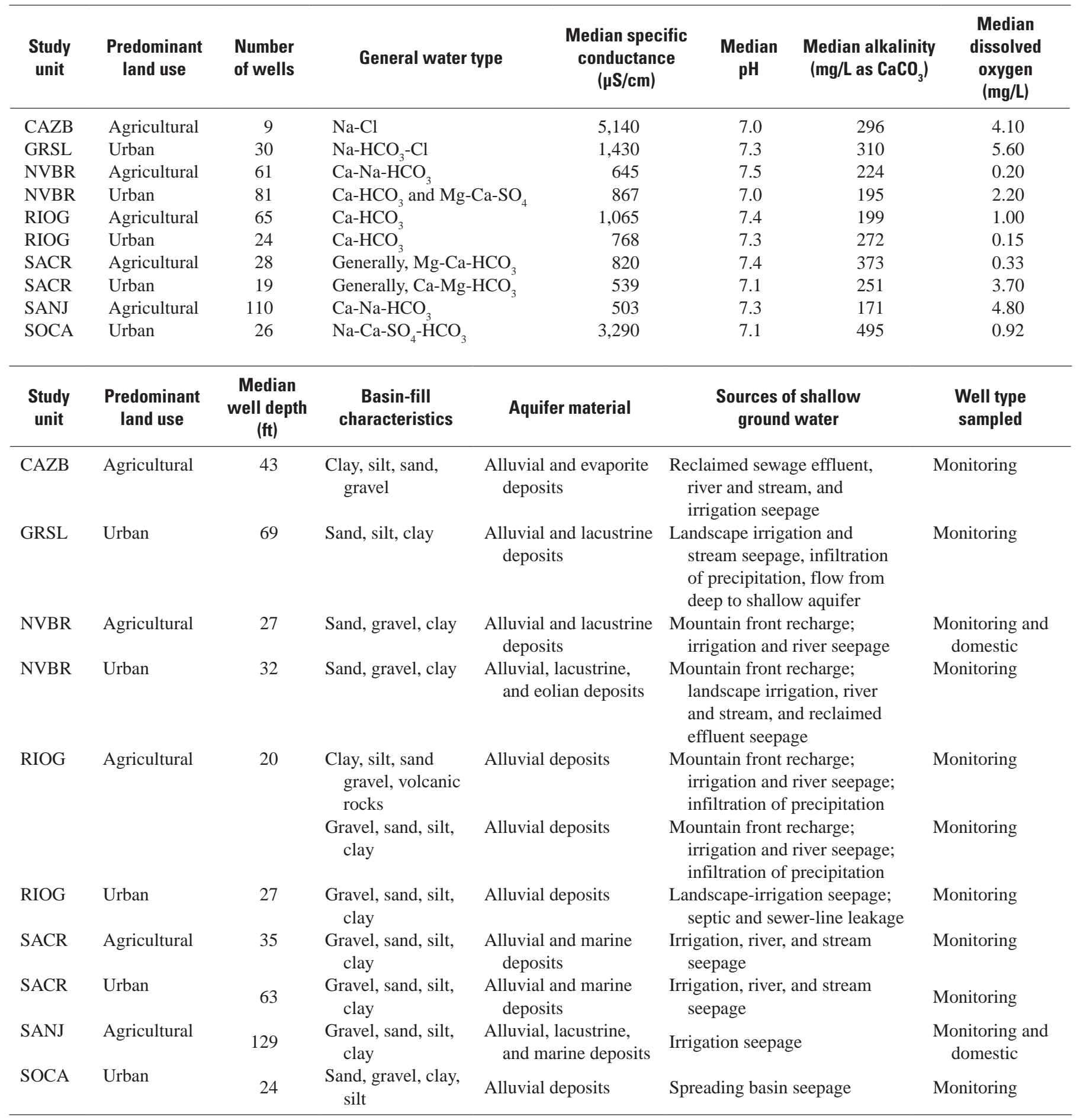




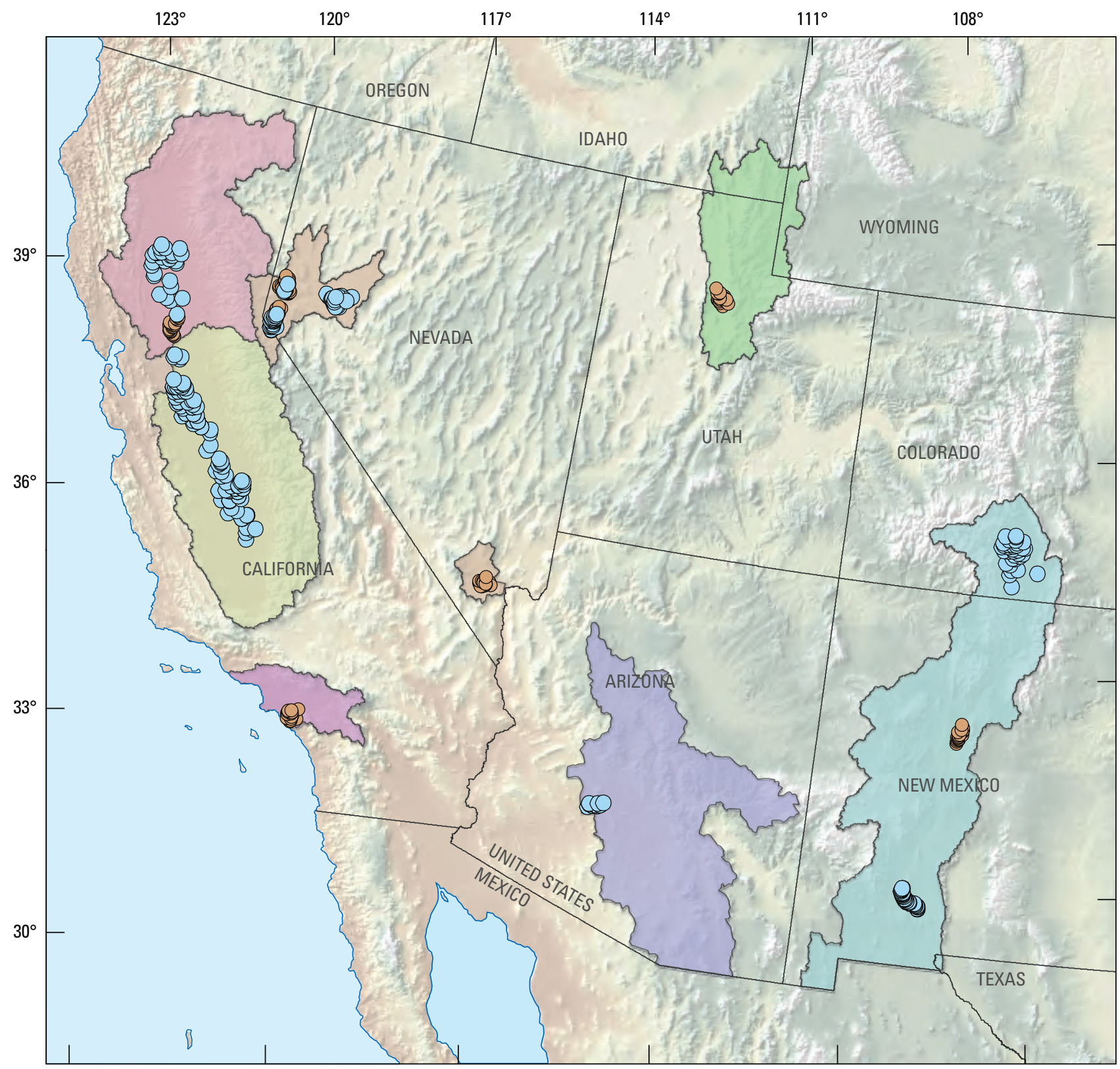

Base from U.S. Geological Survey digital data, 1:24,000-scale, 2005 and Tele Atlas/Geographic Data Technology digital data, 1:100,000-scale, 2005

Albers Equal Area Conic projection: Standard parallells $29^{\circ} 30^{\prime}, 45^{\circ} 30^{\prime}$, central meridian $96^{\circ}$, latitude of origin $23^{\circ}$, North American Datum of 1983.

NAWOA Study Unit

Central Arizona Basins (CAZB)

Great Salt Lake Basins (GRSL)

Nevada Basin and Range (NVBR)

Rio Grande Valley (RIOG)

Sacramento River Basin (SACR)

San Joaquin-Tulare Basins (SANJ)

Southern California Basins (SOCA)

\section{Study well location}

Agricultural

Urban

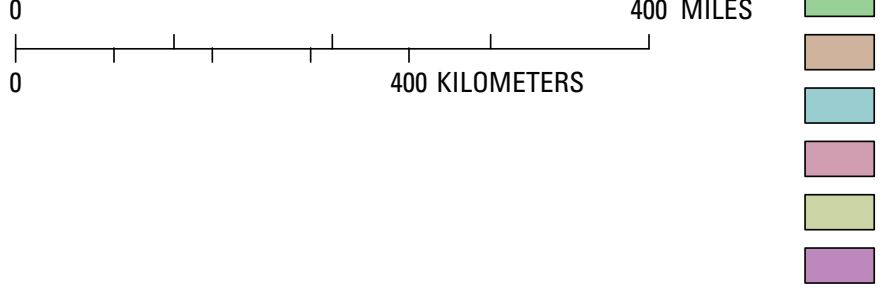

Figure 2. Location of wells sampled in agricultural and urban areas within regional National Water-Quality Assessment (NAWOA) Program study units in the arid to semiarid Western United States, 1993-2004. 


\section{Central Arizona Basins (CAZB)}

Water was sampled from nine wells in agricultural landuse areas in the CAZB that were located in the western part of the West Salt River Valley (fig. 2). The principle crops are citrus, cotton, alfalfa, and grains. In 1995, the population of the West Salt River Valley was estimated to be about 1.4 million (Hitt, 1994), most of which was concentrated in Phoenix and its eastern suburbs. In 1995, about $252 \mathrm{mi}^{2}$ of land in the valley was agricultural and $285 \mathrm{mi}^{2}$ was urban, which corresponded to 19.0 and 21.5 percent of the total land area, respectively (Edmonds and Gellenbeck, 2002).

The West Salt River Valley is a sediment-filled basin of about 1,300 $\mathrm{mi}^{2}$, bordered by desert mountain ranges with altitudes ranging from about 800 to $4,500 \mathrm{ft}$ along the Gila River in the western part of the valley (Edmonds and Gellenbeck, 2002). Sediments tend to be coarse grained near the mountain fronts and fine grained toward the center of the basin. The basin fill consists of alluvial deposits with lenticular beds of clay, silt, sand, and gravel that cannot be traced laterally for long distances (Edmonds and Gellenbeck, 2002). Ground water occurs under unconfined and semiconfined conditions in the basin-fill aquifer. Semiconfined conditions occur locally where clay and silt beds form a confining layer. The agricultural wells from which samples were collected are perforated above these confining beds. Stream deposits overlie the basin fill along and beneath present river channels, forming the most productive and important aquifer in the West Salt River Valley.

The West Salt River Valley aquifer is recharged by the infiltration of runoff along the mountain fronts, major streams flowing through the valley, urban runoff, and irrigation drainage. Precipitation is not a significant source of recharge to the aquifer system (Anderson and others, 1992). Treated effluent originating from Phoenix has been used in agricultural irrigation since the early 1960s. Since 1985, Colorado River water has been used to supplement public and irrigation supplies and can be stored in the basin-fill aquifer (Edmonds and Gellenbeck, 2002). Ground-water discharge is primarily from pumpage, seepage to the Gila River at the southwestern edge of the study area, transpiration by phyreatophytes growing on flood plains, and underflow out of the valley (Anderson and others, 1992).

\section{Great Salt Lake Basins (GRSL)}

The 30 wells included from the GRSL urban study unit are in northern Utah (fig. 2) within Salt Lake Valley, southeast of Great Salt Lake. This urbanized valley covers about $400 \mathrm{mi}^{2}$ and includes the Salt Lake City metropolitan area. In 2000, the population in Salt Lake County was estimated at 898,000 and was growing rapidly, almost doubling between 1963 and 1994 and projected to be about 1,233,000 in 2020 (Thiros, 2003a). Because the natural boundaries of the valley restrict expansion of residential areas, population growth will occur primarily through increased population density. During 1960-94, agricultural land in the valley decreased from 145 to $67 \mathrm{mi}^{2}$ and the amount of urban land increased from 89 to $198 \mathrm{mi}^{2}$ (Thiros, 2003a). In 1994, urban land use in the valley was approximately 63 percent residential, 6 percent commercial, 14 percent industrial, and 17 percent other (includes open and idle spaces, transportation, and utilities (Thiros, 2003a)). Approximately 33 percent of the public-water supply in Salt Lake Valley is ground water. Shallow ground-water resources are used sparingly as stock and domestic supplies (Thiros, 2003a).

Topographic relief between the Wasatch Range and Salt Lake Valley is as much as 7,000 ft. The basin-fill deposits in the valley consist of unconsolidated to semiconsolidated sand, gravel, silt, and clay that were deposited in alluvial fans and as volcanic ash (Hely and others, 1971; Thiros and Manning, 2004). The basin-fill ground-water system in Salt Lake Valley includes a shallow aquifer and a deeper aquifer that are separated by layers of fine-grained sediment. In some areas in the valley, shallow ground water is perched on fine-grained deposits, whereas in other areas it is laterally continuous and forms an aquifer (Thiros, 2003b). The shallow aquifer in the valley generally is unconfined and present within the upper $50 \mathrm{ft}$ of the basin-fill deposits (Thiros, 2003b). Nearly all wells in the valley are screened within sandy deposits that occur throughout the valley, except near the mountain fronts where coarser-grained deposits exist.

Sources of water to the aquifer system within Salt Lake Valley include mountain-front recharge, infiltration of precipitation, and recharge of irrigation water and seepage from streams (Thiros, 2003a; Thiros, 2003b). The shallow aquifer also receives inflow from the deeper aquifer in areas of the valley where this system discharges (Thiros, 2003b). Generally, ground water is discharged from areas in the center of the valley along the Jordan River, and by evapotranspiration (Thiros, 2003a; 2003b). In these discharge areas, water moves upward from the principal aquifer; thus, there is little potential for contamination of the deep aquifer from the shallow aquifer unless pumpage is great enough to reverse the vertical gradient or a contaminant has a greater density than water. 


\section{Nevada Basin and Range (NVBR)}

The 61 agricultural and 81 urban land-use wells from the NVBR study unit are within the watersheds of the Carson and Truckee Rivers and within Las Vegas Valley (ig. 2). The Carson and Truckee River basins are in northwestern Nevada and northeastern California and cover approximately 3,970 and 3,230 $\mathrm{mi}^{2}$, respectively. Las Vegas Valley, located in southern Nevada, encompasses approximately 1,640 $\mathrm{mi}^{2}$ (Covay and others, 1996; Kilroy and others, 1997). In 2000, the Truckee and Carson River basins contained populations of approximately 341,000 and 153,000 people, respectively (Nevada State Demographer's Office, 2006). In the Truckee River basin, the estimated population in the Reno/Sparks metropolitan area increased 55 percent from 1990 to 2005 (Nevada State Demographer's Office, 2006). Carson City showed a population increase of approximately 39 percent during this same period. The Las Vegas area is the most urbanized in the NVBR. In 2000, the population of Las Vegas was approximately 480,000 people. The estimated growth rate of Las Vegas was 112 percent from 1990 to 2005 (Nevada State Demographer's Office, 2006). Most irrigated agriculture in the NVBR study unit is located within the Carson River basin, which covers approximately $180 \mathrm{mi}^{2}$ (Covay and others, 1996; Welch, 1994). The primary crops in the Truckee and Carson River basins are alfalfa, hay, grains, and onions (Nevada Department of Agriculture, 2007). Agricultural and rangeland areas in the Truckee and Carson River basins have become increasingly urbanized over time (Covay and others, 1996). Irrigation is the dominant water use in the Truckee (59 percent) and Carson River (95 percent) basins. Most irrigation water is obtained from the Truckee and Carson Rivers. Ground-water resources are used to supplement surface-water supplies in the Truckee and Carson River basins (Covay and others, 1996). Prior to 1971, ground water was the main source of water supply for the Las Vegas Valley area. In 1990, it was estimated that approximately 80 percent of the water in Las Vegas Valley originates from Lake Mead (Covay and others, 1996).

The Truckee and Carson River basins are located on the eastern side of the Sierra Nevada, where maximum altitudes reach about 10,900 ft (Covay and others, 1996), and extend eastward to Pyramid Lake and Carson Sink, respectively. The Carson and Truckee River basins each contain several groundwater basins that are primarily composed of unconsolidated deposits (Covay and others, 1996) of coarse sand and gravel intermixed with layers of clay. The headwaters of the Las Vegas Valley Hydrographic Area are located in the Spring Mountains to the west, where altitudes reach about 11,900 ft. Lake Mead lies to the southeast at an altitude of about 1,200 ft (Covay and others, 1996). Las Vegas Valley consists of a single ground-water basin composed of unconsolidated to semiconsolidated gravel, sand, and clay deposits underlain by consolidated-carbonate aquifers.
The Truckee and Carson River ground-water basins are hydraulically connected to the Truckee and Carson Rivers, respectively, which are sources of water to shallow aquifers. Aquifer recharge occurs primarily in mountain-front areas. However, shallow aquifers within agricultural areas also can be recharged by infiltration of irrigation water. Irrigation water in Carson Valley originates from surface-water diversions from the Carson and Truckee Rivers and from ground-water pumpage (Welch, 1994). Additionally, constructed wetlands in the Carson River basin store treated-sewage effluent from the Lake Tahoe Basin for use in irrigation (Lico, 1998). The shallow perched aquifers within Las Vegas Valley are influenced largely by irrigation return flow from urban landscapes, whereas the deeper aquifer is mostly confined beneath a thick layer of clay (Covay and others, 1996). As part of an artificial-recharge program, almost 30,000 acre-ft of surface water imported from the Colorado River was injected into the principal aquifer beneath Las Vegas Valley (Lopes and Evetts, 2004). Ground-water discharge is primarily by pumpage; however, a considerable amount of discharge occurs through evapotranspiration in many areas.

\section{Rio Grande Valley (RIOG)}

Both agricultural and urban wells from Rio Grande Valley in the Colorado, New Mexico, and Texas (RIOG) study unit were included in this investigation. These wells are located within the urban area of the Albuquerque Basin (24 monitoring wells) and the agricultural areas of San Luis Valley in south-central Colorado (35 monitoring wells) and Rincon Valley, south-central New Mexico (30 wells) (Anderholm, 1996; 1997; 2002) (figs. 1 and 2). The Albuquerque metropolitan area is the largest population center in Rio Grande Valley with an estimated population of 500,000 in 1990 (Anderholm, 1997). Land use in Albuquerque is approximately 50 percent urban (residential, commercial, and recreational) with intermixed agriculture (Anderholm, 1997). Agricultural lands in the Albuquerque area have been steadily becoming more urbanized (Thorn and others, 1993). San Luis Valley is dominated by the cultivation of alfalfa, native hay, barley, wheat, potatoes, and other vegetable crops (Anderholm, 1996). Rincon Valley is primarily agricultural but also includes residential, urban, vacant, roadways and open-water areas. The main agriculture crops in Rincon Valley include alfalfa, peppers, onions, wheat, cotton, and pecan orchards (Anderholm, 2002). Ground water is used as a potable water source in the Albuquerque area (Anderholm, 1997). Both ground- and surface-water resources are used for irrigation in agricultural areas in the RIOG (Anderholm, 1996; 2002).

The Albuquerque Basin contains basin-fill deposits as thick as $14,000 \mathrm{ft}$ and is bounded by mountainous areas along the north, east, and south margins and by an area of 
low topographic relief along the west. The aquifer materials are composed of gravel, sand, silt, and clay and have large variations in hydraulic conductivity as a result of grain size and sorting (Anderholm, 1997). San Luis Valley covers approximately 7,500 $\mathrm{mi}^{2}$, has an average altitude of 7,700 ft, and is bounded by mountains with several peaks over $14,000 \mathrm{ft}$ (Anderholm, 1996). San Luis Valley consists of thick basinfill deposits interbedded with clay, silt, gravel, and volcanic rocks (Burroughs, 1981; Emery and others, 1973). The two main aquifers in this valley are the confined and unconfined, separated by a confining zone approximately 60-100 ft below land surface that underlies a large part of the center of the valley (Emery and others, 1973; Anderholm, 1996). Rincon Valley in south-central New Mexico covers approximately $76 \mathrm{mi}^{2}$, is relatively flat, and is bordered by steep bluffs 50$100 \mathrm{ft}$ high (Anderholm, 2002). The shallow aquifer beneath Rincon Valley is within the upper basin-fill deposits. These upper deposits generally are less than $80 \mathrm{ft}$ thick and consist of gravel, sand, silt, and clay-sized sediment (King and others, 1971; Anderholm, 2002).

The main sources of recharge to the shallow aquifer in the Albuquerque Basin are infiltration of surface water, sewage effluent, and precipitation. The main sources of discharge are ground-water outflow to adjacent areas, groundwater withdrawals, and evapotranspiration (Anderholm, 1997). Ground-water movement within the Albuquerque Basin is dominated by cones of depression in the water table resulting from ground-water withdrawals. Ground-water levels have declined as much as $160 \mathrm{ft}$ east of Albuquerque, resulting in reversals in ground-water flow direction (Anderholm, 1997). Within San Luis Valley, recharge to the unconfined aquifer comes from infiltration of precipitation, surface-water infiltration, irrigation seepage, and inflow of ground water from adjacent areas and deeper aquifers (Powell, 1958). Since 1990 , irrigation water from the Rio Grande is diverted into irrigation canals. The primary mechanism of discharge from the unconfined aquifer is evapotranspiration; however, upward leakage to streams and ground-water flow to the south also are involved (Anderholm, 1996). Since the 1880s, changes in agricultural practices within San Luis Valley such as sources of irrigation water, location of irrigated areas, crop rotation, and the application of irrigation water to crops have affected the ground-water flow system and likely ground-water quality (Hearne and Dewey, 1988; Anderholm, 1996). Fertilizers and pesticides are applied to fields in irrigation water and by aerial and land-based spraying (Anderholm, 1996). In Rincon Valley, areas are flood irrigated with surface water diverted from the Rio Grande River. Fertilizer is applied to crops several times during the year either directly to the soil or by application in irrigation water. The amounts of specific pesticides used in Rincon Valley are unknown (Anderholm, 2002). Ground-water recharge within Rincon Valley occurs primarily through the infiltration of irrigation water, precipitation, water from the
Rio Grande, and inflow of water from adjacent areas (King and others, 1971; Anderholm, 2002). Discharge of ground water from Rincon Valley primarily is through discharge to the Rio Grande River and agricultural drains, ground-water outflow, pumpage, and evapotranspiration (Anderholm, 2002).

\section{Sacramento River Basin (SACR)}

The 28 agricultural and 19 urban wells included from the SACR study unit are within Sacramento Valley in northcentral California (fig. 2). The Sacramento River basin covers approximately 27,000 $\mathrm{mi}^{2}$ and has been farmed and irrigated since the mid-1800s (Domagalski, Knifong, and others, 2000). Sacramento Valley is in the northern third of California's Central Valley, and approximately 3,000 $\mathrm{mi}^{2}$ of the valley is irrigated (Hull, 1984; Page, 1986). Until as recently as 1975, agriculture was the dominant land use in SACR, with cropland and pasture occupying the largest amount of acreage (Shelton, 2005). Major crops grown in the valley are rice, orchards, grains, and tomatoes (Domagalski and others, 1998). Most of the population in Sacramento Valley resides in the Sacramento area. The population of Sacramento County increased by 41 percent from 1980 to 1995 (Shelton, 2005). Both surface and ground water are used as a potable water supply in the Sacramento Valley (Dawson, 2001; Solley and others, 1998a). The use of ground-water resources has been increasing in the Sacramento Valley, and in 1995 approximately 40 percent of irrigation and 44 percent of the potable-water supplies were obtained from ground water (Shelton, 2005).

Sacramento Valley is a northwest-trending, asymmetric structural trough, filled with marine and continental rocks and sediments (Hull, 1984; Page 1986; Domagalski, Dileanis, and others, 2000). Fine-grained sediments compose greater than 50 percent of aquifer materials in most areas of the valley, with approximately $200 \mathrm{ft}$ of the top unconfined (Page, 1986; Bertoldi and others, 1991). The alluvial deposits are a heterogeneous mix of gravel, sand, silt, and clay (Helley and Harwood, 1985; Dawson, 2001; Shelton, 2005).

During the last century, changes in the use of surface- and ground-water resources in the Sacramento Valley have greatly influenced the hydrologic system. As a result of pumping for irrigation and potable water, cones of depression have developed in the northern and southern areas of the valley and depth to water in shallow aquifers has declined (Bertoldi and others, 1991; Shelton, 2005). Aquifer recharge occurs primarily through infiltration of precipitation, water from the American and Sacramento Rivers, and irrigation water (Dawson, 2001). Recharge to the Sacramento Valley aquifer occurs primarily in the upper reaches of river channels and in irrigated areas, and ground-water discharge primarily occurs as pumpage in the southern part of the valley and loss to streams (Bertoldi and others, 1991). 


\section{San Joaquin-Tulare Basins (SANJ)}

The 110 agricultural wells sampled within the SANJ study unit are located on the eastern side of San Joaquin Valley in central California (fig. 2). San Joaquin Valley can be divided into two primary basins: the San Joaquin and Tulare. Together these two basins occupy nearly $31,200 \mathrm{mi}^{2}$ of the eastern alluvial fan of the Coast Ranges, San Joaquin Valley, and the western alluvial fan of the Sierra Nevada (Burow, Stork, and Dubrovsky, 1998). San Joaquin Valley has a long history of intense farming and irrigation. In 1987, approximately 10.5 million acres were dedicated to farmland where approximately one-half of the total value of agricultural production in California was generated (Gronberg and others, 1998). Major products include livestock and livestock products, fruit and nuts, cotton, corn, vegetables, hay, grains, and other crops. Together, vineyards, almonds, and a rotational crop grouping of corn, alfalfa, and vegetables cover 47 percent of the agricultural land in the eastern alluvial fan region (Burow, Shelton, and Dubrovsky, 1998). Although SANJ is still a very important agricultural area, urban land use has become increasingly important as the cities grow to accommodate the rise in population. The major urban areas include Bakersfield, Fresno, Modesto, and Stockton (Burow, Stork, and Dubrovsky, 1998). Large urban centers with populations in excess of 450,000 people rely predominantly on ground-water resources for potable water (Burow and others, 1999). Both surface water and ground water resources are used for irrigation in the SANJ agricultural areas (Burow and others, 1999)

Alluvial-fan deposits of San Joaquin Valley are composed predominantly of coarse-grained sediments near the head of each fan that become finer toward the axis of the valley (Bertoldi and others, 1991; Burow, Stork, and Dubrovsky, 1998). The aquifer system is made up of continental deposits overlying marine sediments. The upper parts of the aquifer are unconfined to semi confined, whereas the deeper aquifer is confined (Poland and Lofgren, 1984; Bertoldi and others, 1991; Burow, Stork, and Dubrovsky, 1998). Historically, lacustrine diatomaceous clay deposited within San Joaquin Valley confined deeper parts of the aquifer, primarily along the western areas of the valley, thinning toward the eastern side of the valley (Page, 1986; Bertoldi and others, 1991; Planert and Williams, 2000). However, the effectiveness of this clay confining layer is questionable (Bertoldi, 1991; U.S. Geological Survey, 2000). The sedimentary deposits in San Joaquin Valley are composed of gravel, sand, silt, and clay.

The hydrologic system of San Joaquin Valley is complex, in part because of the heterogeneous nature of the deposits. Ground water generally flows in a southwestern direction toward the center of the valley (Bertoldi and others, 1991). Dominant sources of recharge to the aquifer system are infiltration of water from rivers and streams, precipitation, and irrigation seepage (Burow and others, 1999); however, infiltration of irrigation water has replaced infiltration of intermittent stream water and precipitation as the primary mechanism of recharge (Williamson and others, 1989). In the hydrologically closed Tulare Basin, most ground water flows to the Tulare Lake area and is discharged by evapotranspiration. Toward the center of San Joaquin Valley, the hydraulic gradient has been reversed from an upward to downward direction as a result of heavy groundwater pumpage for purposes of irrigation and public supply (Williamson and others, 1989; Bertoldi and others, 1991). Depth to water ranges from approximately $20 \mathrm{ft}$ below land surface along the eastern edges of San Joaquin Valley to about $400 \mathrm{ft}$ below land surface in the southern areas of the valley (Burow, Stork, and Dubrovsky, 1998).

\section{Southern California Basins (SOCA)}

Twenty-six urban land-use wells were sampled in the SOCA study unit (fig. 2). This urbanized area is located on the Pacific coastline between Los Angeles and San Diego, California. Nearly 4 million people live within the Santa Ana Basin, and by the year 2020, the population is estimated to increase by more than 50 percent (Hamlin and others, 2002). Estimates of land use within the Santa Ana watershed are 35 percent urban, 10 percent agriculture, and 55 percent open space. Population density within developed areas in the SOCA study unit is about 3,000 people per square mile (Belitz and others, 2004). The $2,700 \mathrm{mi}^{2}$ of the Santa Ana watershed can be subdivided into three primary ground-water basins: the San Jacinto, the Inland, and the Coastal Basins (Hamlin and others, 2005). The 26 wells included in this study are located within the $100-\mathrm{mi}^{2}$ Coastal Basin, where land use is almost entirely urban (Scott Hamlin, U.S. Geological Survey, written commun., 2005). Ground water is used as the primary source of fresh water in the SOCA study unit (Hamlin and others, 2005). The Coastal Basin has been subdivided into the Main and Irvine subbasins, which are hydrologically connected (Herndon and others, 1997).

The Main and Irvine subbasins are alluvium-filled valleys. The Main subbasin has a relatively small area of mountain-front recharge, approximately $50 \mathrm{mi}^{2}$ along the Santa Ana River, consisting of unconsolidated sands and gravels with occasional lenses of clay and silt (Herndon and others, 1997). The Irvine subbasin contains clay and silt deposits that are typically $200-1,000 \mathrm{ft}$ thick. The Irvine subbasin is composed of thin aquifers that consist primarily of silty sand (Herndon and others, 1997). Water quality in the Irvine subbasin is suitable for irrigation, but generally not for municipal supply (Hamlin and others, 2002). Within the Coastal Basin, the freshwater-bearing deposits are as much as 
4,000 ft thick (Herndon and others, 1997). The shallow wells sampled during the land-use investigation are located in an area where the deeper aquifer is confined (Hamlin and others, 2005).

The hydrologic cycle within the Coastal Basin is greatly affected by human activities: ground-water pumping, engineered-recharge operations, and discharge of treated wastewater to local streams. Streams and rivers draining the mountains are diverted to ground-water recharge facilities. Eventually this diverted water is discharged back into the Santa Ana River upstream of the Coastal Basin as treated wastewater. The Coastal Basin aquifer system is recharged with water from the Santa Ana River, storm runoff, and water imported from the Colorado River and northern California through spreading basins (Hamlin and others, 2002; Belitz and others, 2004). The Orange County Water District manages approximately 200,000-250,000 acre-ft of engineered recharge to the aquifer system annually (Hamlin and others, 2002). Pumpage is the major component of ground-water discharge in the Coastal Basin (Herndon and others, 1997).

\section{Methods}

\section{General Study Design}

Data used in this study (fig. 2) were obtained from 19 NAWQA land-use studies in the Western United States (appendixes A-D). These studies were designed to examine the influence of agricultural and urban land-use activities on the quality of shallow ground water by using data collected with consistent sampling protocols. The national study design was intended to provide data useful to understanding water-quality conditions in areas of intensive agricultural or urban land use at both national and regional scales (Gilliom and others, 2006). In most areas, approximately 20 to 30 relatively shallow wells within the same aquifer were sampled (Gilliom and others, 1995; Koterba and others, 1995). Ground-water sampling networks were established in areas where shallow ground water would reflect recent land-use activity and the attenuation properties of the aquifer (Squillace and others, 2004).

Nutrient enrichment has been documented in agricultural areas. In the Eastern United States, periods of drought were shown to increase nitrogen concentrations in shallow ground water beneath agricultural areas near Chesapeake Bay (Stevenson and others, 1986). Nutrients were sampled during the NAWQA land-use investigations because of the increasing concentrations in shallow ground water in areas influenced by agriculture and other human-related activities as noted in previous studies (Hirsch and others, 1988).
The 86 pesticides targeted for investigation were selected on the basis of their agricultural and nonagricultural use, potential environmental significance, and the ability of the USGS National Water Quality Lab (NWQL) to quantify them (Larson and others, 1999; U.S. Geological Survey, 1999). The 55 VOCs targeted for analysis were selected on the basis of available information on their occurrence, human and ecological health concerns, ozone depletion potential, use as a fuel additive, and analytical capabilities of the USGS NWQL (Bender and others, 1999).

All samples were analyzed by the USGS NWQL in Denver, Colorado. In circumstances where concentrations of an analyte are sufficiently low to be considered below a detectable quantity, the NWQL reports these concentrations as less than the Laboratory Reporting Limit (LRL). When using the LRL, the risk of reporting a non-detectable analyte concentration when the analyte is actually present (false negative) is less than 1 percent (Childress and others, 1999). The LRL typically is twice the long-term method detection level (LT-MDL). The NWQL LT-MDL is derived by using the standard deviation of at least 24 measurements of spikedmatrices containing the analyte(s) of interest. The actual LT-MDL is the minimum analyte concentration(s) measured with 99-percent confidence that the concentration is, in fact, greater than zero. The NWQL reports estimated analyte concentrations when concentrations fall between the LT-MDL and LRL (Childress and others, 1999). Improvements in analytical methods over the years have resulted in changes in LT-MDLs. In circumstances where the LT-MDL for an analyte varies during the period of data collection, concentration data for that constituent is assessed on the basis of the greatest LT-MDL during that period. All constituent concentrations below this LT-MDL are considered to be below detection. This procedure is called recensoring. Recensoring is done so that old data, typically with higher LT-MDLs, can be compared with more-recent data collected using lower limits. All nutrient concentrations were recensored to the greatest LRL within the data set (table 3 ) for each respective nutrient species because the LT-MDL did not cover the entire sampling period (July 1993 to September 2004).

For the purposes of this report, estimated pesticide concentrations reported by the NWQL were considered detectable concentrations. Because of improvements in analytical sensitivity over the years, VOC data were recensored to a value of $0.2 \mu \mathrm{g} / \mathrm{L}$ (Zogorski and others, 2006). Although recensoring VOC data to $0.2 \mu \mathrm{g} / \mathrm{L}$ reduced the number of detections of some VOCs, this procedure did not substantially change relations among data when compared to recensoring data using maximum LT-MDLs. 
Table 3. Long-term method detection and censoring limits used during data analyses for this regional study.

[Censoring limit: maximum censored value contained in data set (LRL). Long-term MDLs: dates in parentheses are those for which the long-term MDLs were available. Abbreviations: LRL, laboratory reporting limit; MDL, method detection level; $\mathrm{N}$, nitrogen; $\mathrm{P}$, phosphorus; mg/L, milligram per liter; $\mu \mathrm{g} / \mathrm{L}$, microgram per liter]

\begin{tabular}{|c|c|c|}
\hline $\begin{array}{c}\text { Constituent } \\
\text { (filtered) }\end{array}$ & $\begin{array}{c}\text { Censoring } \\
\text { limit }\end{array}$ & $\begin{array}{l}\text { Long-term } \\
\text { MDLs }\end{array}$ \\
\hline \multicolumn{3}{|c|}{ Nitrogen species, in $\mathrm{mg} / \mathrm{L}$ as $\mathrm{N}$} \\
\hline Ammonia & 0.041 & $\begin{array}{c}\text { 0.005-0.024 } \\
\text { (1999-Present) }\end{array}$ \\
\hline $\begin{array}{l}\text { Kjeldahl (ammonia } \\
\quad+\text { organic) nitrogen }\end{array}$ & 0.2 & $\begin{array}{c}0.05 \\
\text { (1998-Present) }\end{array}$ \\
\hline Nitrite & 0.01 & $\begin{array}{c}0.001-0.004 \\
\text { (2000-Present) }\end{array}$ \\
\hline Nitrite + nitrate (nitrate) & 0.1 & $\begin{array}{c}0.009-0.03 \\
\text { (1999-Present) }\end{array}$ \\
\hline
\end{tabular}

\begin{tabular}{lcc}
\hline \multicolumn{3}{c}{ Phosphorus species, in $\mathrm{mg} / \mathrm{L}$ as $\mathrm{P}$} \\
\hline Total phosphorus & 0.01 & $0.0018-0.03$ \\
& & $(1998-$ Present $)$ \\
Orthophosphorus & 0.01 & $0.003-0.009$ \\
& & $(2000-$ Present $)$ \\
\hline
\end{tabular}

\begin{tabular}{lcc}
\hline & Organic compounds, in $\mu \mathrm{g} / \mathrm{L}$ \\
\hline Pesticides & None & $0.001-0.021$ \\
& 0.2 & $(1980-$ Present $)$ \\
$\begin{array}{c}\text { Volatile-organic } \\
\text { compounds }\end{array}$ & $0.015-0.91$ \\
\end{tabular}

\section{Creation of Databases}

Chemical data used in this report are from samples collected between 1993 and 2004 for the NAWQA land-use studies (appendixes A-D). Samples from the 273 agricultural and 181 urban wells were collected following NAWQA protocols (Koterba and others, 1995). Most data are stored in a central database (NAWQA Data Warehouse) and for this investigation were compiled into Excel spreadsheets. Data from an agricultural area east of Reno, Nevada, collected as part of a 2001 investigation of a childhood leukemia cluster (Seiler and others, 2005) were included in data from the NVBR study unit. Data for the additional agricultural wells for the NVBR study unit were obtained from the NWIS database.
Land use near the wells was classified by using a three-tiered approach that incorporated watershed characteristics using the National Land Coverage Dataset (NLCD) that was enhanced for the purposes of NAWQA (NLCDE) (David Mueller, U.S. Geological Survey, written commun., 2006).

Ancillary data used in this analysis included well-specific data such as the depth of the screened interval, and geospatial data in GIS databases related to land use and soil/aquifer characteristics (Hitt 1994; Solley and others, 1998b; Nakagaki and Wolock, 2005). A 500-meter buffer around each well was used to characterize land use around each well. Geospatial data included agricultural pesticide use, irrigation practices, general crop types, fertilizer use, percent urbanization, population density, soil characteristics, general lithology, and average annual precipitation (tables 1, 4). Soil-hydrologic groups and soil and permeability characteristics were obtained from modified STATSGO data (U.S. Department of Agriculture, 1994). Agricultural factors, such as irrigation and crop type, were obtained from Enhanced National LandCoverage Datasets (NLCDE) by using 30-meter land-cover grids, published in 2005 .

Regionally, pesticide-use data is available on a countyscale basis and extrapolated into the 500-meter buffer zones around each of the agricultural wells (Thelin, 2005a, b). The extrapolation was based on the average annual-application rate of pesticides state-wide, the percent acreage of a crop treated with a pesticide, and the percentage of agricultural-land use within the buffer area (Naomi Nakagaki, U.S. Geological Survey, written commun., 2005). Unfortunately, this level of pesticide-use information was not sensitive enough for the purposes of the data analyses contained in this report. Selected California pesticide-use data are available at a township-andrange scale. Pesticide-use data available at township-and-range scale were summed and extrapolated over each townshipand-range area. The effectiveness of using township-andrange-scale data with respect to county-scale pesticide-use data was evaluated by using pesticide data after extrapolation into 500-meter buffer areas around each of the wells. An assumption was made that the township-and-range data, being at a finer scale, was more accurate than the available countylevel data.

Ancillary data for each well was compiled into an Excel® spreadsheet (appendix D). An Access relational database was created from the Excel spreadsheets that linked chemical and ancillary data so that relations between contaminants and land use could be evaluated. 
Table 4. Median values for selected well, aquifer, and land-use characteristics for regional National Water-Quality Assessment Program study units in the arid to semiarid Western United States, 1993-2004.

[Number in parentheses indicates number of wells sampled. Abbreviations: CAZB, Central Arizona Basins; GRSL, Great Salt Lake Basins; NVBR, Nevada Basin and Range; RIOG, Rio Grande Valley; SACR, Sacramento River Basin; SANJ, San Joaquin-Tulare Basins; SOCA, Southern California Basins; All, agricultural and urban land uses; Ag, agricultural land use; Urb, urban land use; ft, foot; kg, kilogram; people $/ \mathrm{km}^{2}$, people per square kilometer; kg/km²,

kilogram per square kilometer; $\mathrm{m}$, meter; nd, not determined]

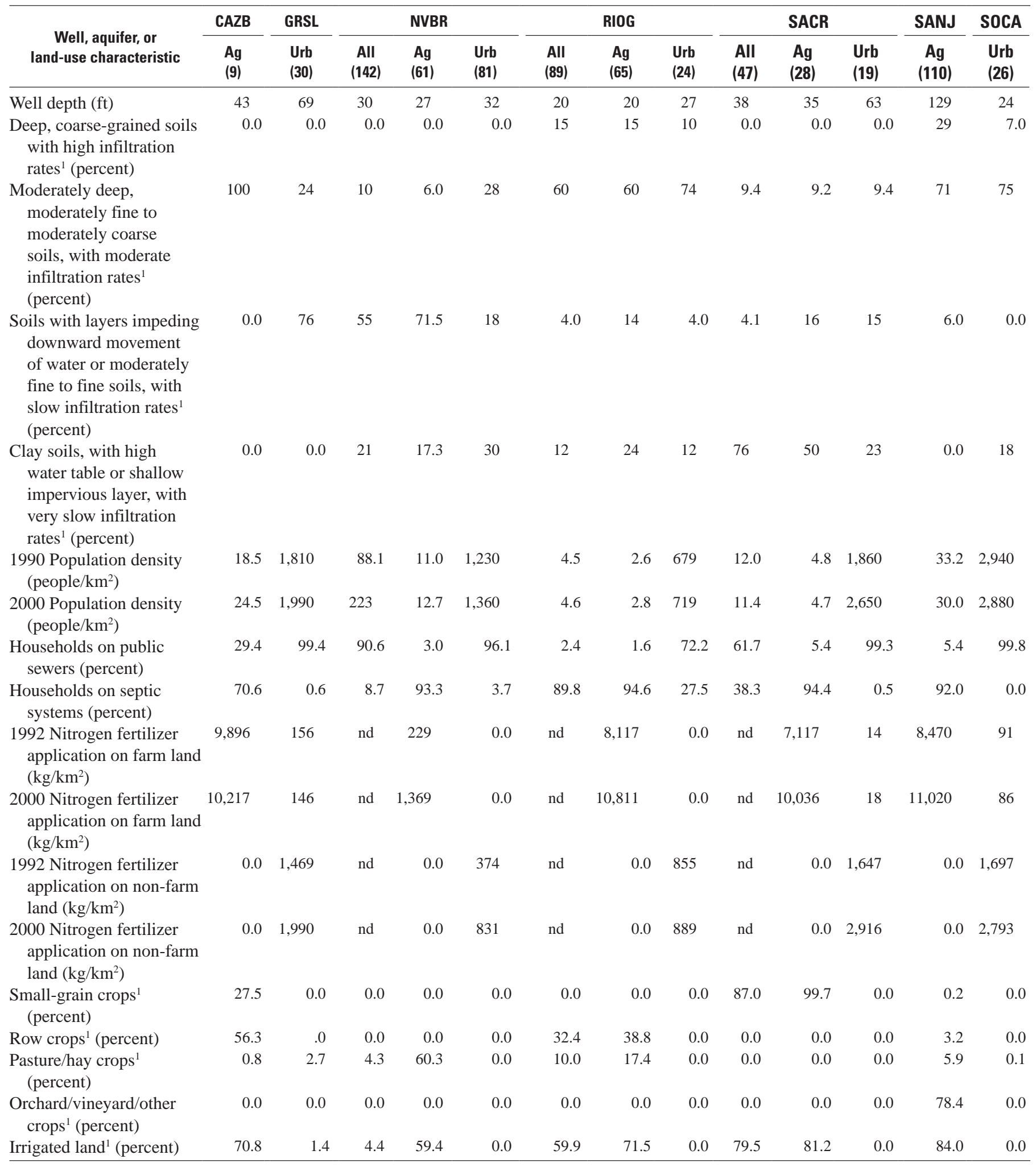

${ }^{1}$ Percentage of land area in designated class within 500-m buffer around the well. 


\section{Statistical Analyses}

Recensored data were used for the frequency of detection analyses. Univariate correlation analyses between concentration and (or) detection frequencies were made by using the Spearman Rank method. Where concentration and detection-frequency comparisons were made among land uses and (or) study units, the nonparametric Kruskal-Wallis statistical method was used (SYSTAT Software Inc., 2004).

Statistical summaries of chemical quality for the NAWQA study units can be biased if water from some wells is sampled more frequently than that from other wells. Where water from wells was sampled multiple times, bias from multiple measurements at the same site was removed by using the most recent analysis. Selecting the most recent analysis is a simple process that uses the best available analytical methods and is unbiased toward high or low values when there are seasonal or annual trends in the data. An alternative method for removing bias by calculating median and average values for a given well was rejected because robust methods are required to calculate summary statistics when censored data are present. Estimation methods could not be used, however, because many of the wells had only two or three analyses, which is insufficient for their use.

Multivariate-logistic regression was used (Steinberg and Colla, 2004) to evaluate a dependent variable (response variable) to one or more independent variables (predictor variables). Logistic regression builds a predictive model by evaluating the relation between observed and predicted values and is a valuable tool for evaluating data containing censored data (Rupert, 2003). Logistic regression is an iterative technique in which potential explanatory variables are added and removed from the model in order to achieve the model with the highest predictive power. The best model is one that has the greatest overall predictive power using the fewest variables (Hosmer and Lemeshow, 1989). Generally, "maximum likelihood" numerically indicates the probability of obtaining observed results in a given dataset given a set of parameters. The "log-likelihood" function is essentially "maximum likelihood" on a logarithmic scale (Hosmer and Lemeshow, 1989). Two models containing different explanatory variables can be compared by evaluating their loglikelihoods (Hosmer and Lemeshow, 1989). The McFadden's rho-squared is similar to the correlation coefficient, $\mathrm{R}^{2}$, in linear regression. The higher the McFadden's rho value, the stronger the correlation is between the independent and dependent variable(s) (Steinberg and Colla, 2004). A logistic model is considered sufficiently strong when the loglikelihood ratio is maximized (Hosmer and Lemeshow, 1989; Rupert, 2003) and the overall McFadden's rho-squared lies between 0.2 and 0.4 (Steinberg and Colla, 2004). In this study, logistic regression was used to examine potentially significant explanatory variables for the detection of pesticides and VOCs. A predictive model for the exceedance of the USEPA 10-mg/L MCL for nitrate also was created.

\section{Data Limitations}

Given the regional scope of this investigation, possible complications in data analysis could make it difficult to make definitive conclusions. These complications include, but are not limited to, the quality and availability of necessary GIS datasets, previous undetected human activities that may have influenced shallow ground-water quality, and unknown upgradient contaminant sources (Squillace and others, 2004).

Wells were added and dropped from established NAWQA ground-water networks from 1993 to 2004, resulting in changing sampling sites and irregular sampling intervals. The number of wells sampled during the different NAWQA land-use studies differed, and simple statistical summaries of the data cannot provide reliable descriptions of contaminant concentrations in the regional-study area. For example, water from only 9 agricultural wells was sampled in the CAZB study unit, whereas 110 ground-water samples were collected in the SANJ study unit. The national land-use study design targeted agricultural and urban areas to evaluate contaminant occurrence and distribution resulting from these types of landuse activities (Gilliom and others, 2006). Only three study units, NVBR, RIOG, and SACR, had both agricultural and urban areas represented whereas the other study units were representative of either urban or agricultural land use, but not both.

Generally, ground-water redox potential $(\mathrm{pE})$ and common redox-couple concentrations (arsenite and arsenate; sulfide and sulfate; and ferrous- and ferric-iron species) were not measured during NAWQA land-use studies. Given that redox condition is an important environmental factor influencing the occurrence of many contaminants, the lack of this information in conjunction with the other aforementioned limitations makes it difficult to identify causeand-effect relations between contaminant occurrence and available ancillary data. Although the redox data were largely unavailable for data analyses, a generalized ground-water redox condition was estimated by using dissolved oxygen, nitrite and nitrate, and iron concentrations in ground water.

Regionally, pesticide-use data were available on a countyscale basis. The extrapolation of these data into 500-meter buffer areas surrounding each well inherently included a margin of error. When localized pesticide-use data are extrapolated throughout a larger area, such as an entire county, areas where a pesticide was not used may be identified as an area of pesticide use. Alternatively, areas where there is moreintensive pesticide use may be identified as areas with less intensive use. The ability to show cause-and-effect relations is greatly reduced. Differences in pesticide use patterns, crop types, and availability of refined GIS datasets made it difficult to identify relations among various land-use characteristics and pesticide occurrence. 


\section{Water-Quality Conditions}

\section{Oxidation-Reduction Conditions}

The behavior of contaminants within the environment is influenced by many factors such as the chemical and physical properties of the contaminant and the physical, geochemical, and biological nature of the surrounding environment in which the contaminant is exposed. An important environmental parameter that can have great influence on the toxicity and mobility of contaminants is redox condition. The presence of oxygen generally is indicative of an aerobic or oxidizing environment, and the absence of oxygen is indicative of an anaerobic or reducing environment. Oxygen-reduction (Redox) condition varied among the NAWQA study units, possibly influencing the occurrence of nutrient, pesticides, and VOCs. For example, nitrate can be removed by denitrification from anoxic ground water even though fertilizers might be contributing substantial amounts of nitrate to the groundwater system. As a result, distinguishing the effects of redox condition from land use may be complex. Dissolved-oxygen (DO) concentration was the most important explanatory variable for the detection frequency of 6 of the 14 most frequently detected VOCs in shallow ground water in recently urbanized areas throughout the United States (Squillace and others, 2004), and in addition to VOCs and nitrate, some pesticides also are sensitive to redox condition (Langmuir, 1997; Barbash, 2003).

Dissolved-oxygen concentrations were not significantly different in water from wells in agricultural and urban landuse settings (fig. $3, p=0.554$ ). This is because of the large variability in DO concentration among and within each of the study units. In four of the study units, DO concentrations ranged from less than 0.2 to greater than $7.0 \mathrm{mg} / \mathrm{L}$ (fig. 4). Within individual study units, DO concentrations between water from wells from agricultural and urban areas can be strikingly different. In the NVBR and SACR study units, DO concentrations are significantly lower in the samples collected from agricultural wells than from the urban wells $(p<0.05)$, and the converse is true in the RIOG study unit $(p=0.001)$.

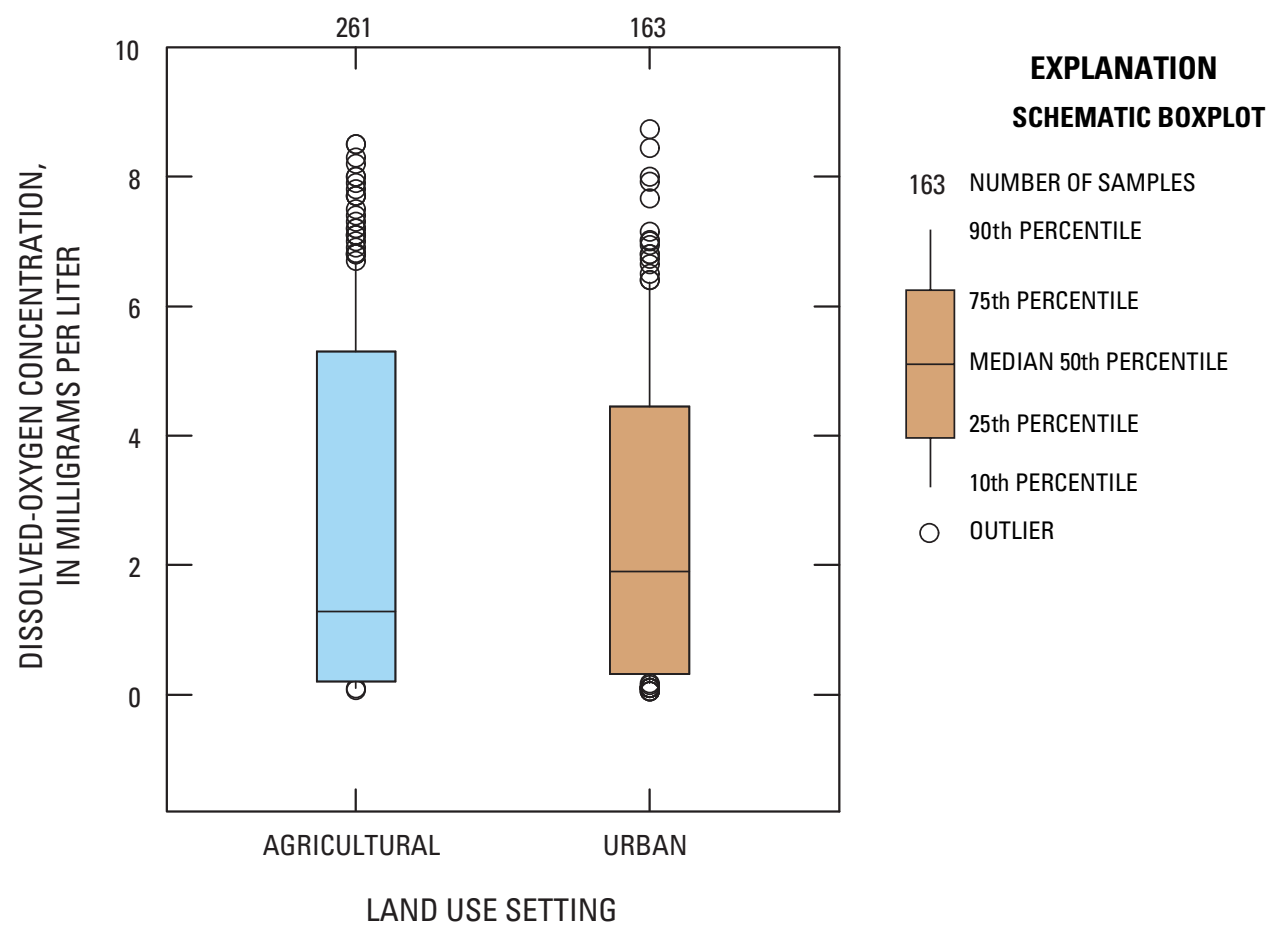

Figure 3. Dissolved-oxygen concentration in ground water from agricultural and urban areas within regional National Water-Quality Assessment Program study units in the arid to semiarid Western United States, 1993-2004. 


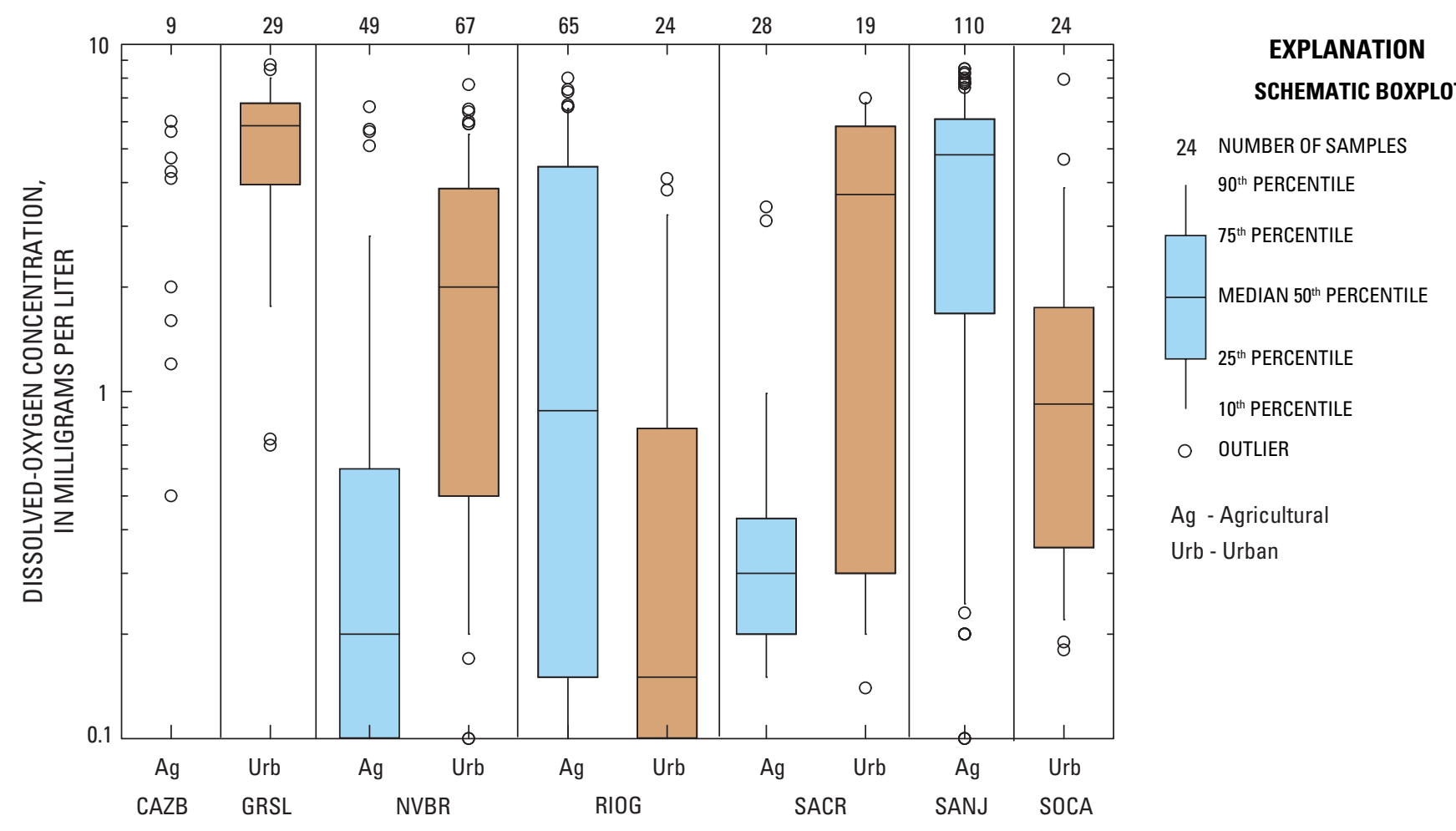

Figure 4. Statistical relation of dissolved-oxygen concentration among regional National Water-Quality Assessment Program study units and respective land-use settings, in the arid to semiarid Western United States, 1993-2004. See figure 1 for definitions of study unit abbreviations.

\section{Nutrients}

\section{Distribution of Nutrient Species}

The ratio, expressed as a percentage, of nitrite to nitrite plus nitrate concentration was used to determine whether nitrite or nitrate is the dominant species in sampled ground water and whether there was a difference between agricultural and urban areas. Nitrite concentration is measured and reported independently, and as a component of the nitrite plus nitrate analysis. The ratio of the two measurements was calculated for each sample in the database, where concentrations of nitrite plus nitrate were measurable. The ratios show that nitrate is the dominant species in both agricultural and urban samples (fig. 5A, $\underline{B}$ ). Because nitrate is the dominant species identified in all samples, measured nitrite plus nitrate concentrations will be referred to as nitrate concentrations in the remainder of the report.

The ratio of the ammonia concentration to the Kjeldahl nitrogen (ammonia plus organic nitrogen) concentration (fig. $5 C, \underline{D}$ ) indicates that the reduced nitrogen is predominantly organic; ammonia was the dominant species in only 32 percent of the samples. The data indicate that reduced nitrogen species is the same between agricultural and urban areas. However, reduced-nitrogen speciation varies among study units. For example, a comparison of the percent ammonia from agricultural sites in the NVBR and RIOG study units shows that the median is 57 percent in the NVBR study unit ( $\mathrm{n}=39)$, and only 8 percent in the RIOG unit $(\mathrm{n}=37)$.

The ratio of orthophosphorus to total-phosphorus concentrations in filtered ground water (fig. $5 E$ ) indicates that orthophosphorus is the dominant phosphorus species. The percentage of orthophosphorus commonly exceeds 100 percent of the total phosphorus concentrations, particularly at low concentrations. This is the result of rounding analytical results, accuracy effects that occur at low-concentration determinations, and possible matrix interferences. The data indicate that agricultural samples contained higher amounts of orthophosphorus than samples from urban areas (fig. $5 F, p=$ 0.016). 

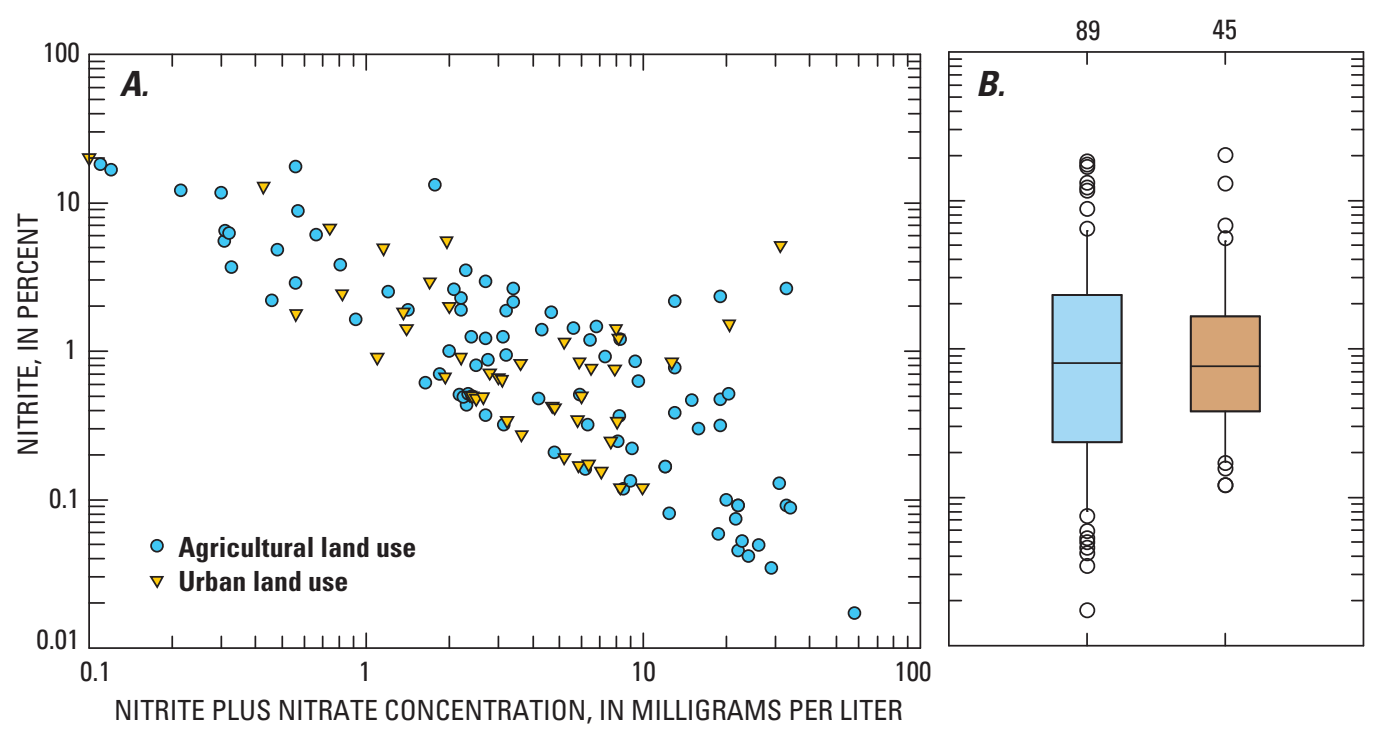

EXPLANATION SCHEMATIC BOXPLOT

163 NUMBER OF SAMPLES

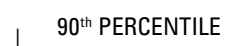

$75^{\text {th }}$ PERCENTILE MEDIAN 50 $0^{\text {th }}$ PERCENTILE $25^{\text {th }}$ PERCENTILE $10^{\text {th }}$ PERCENTILE

OUTLIER
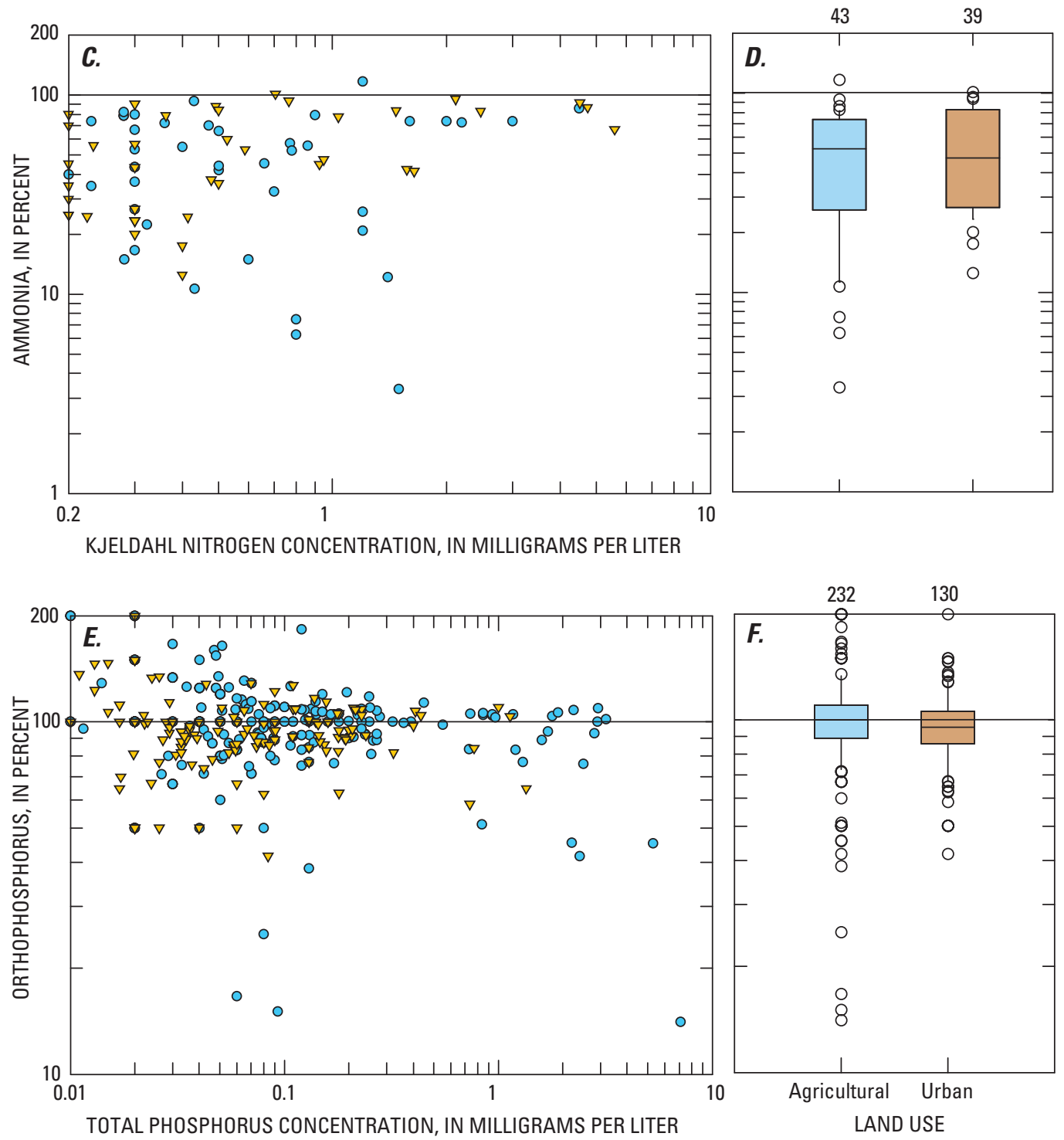

Figure 5. Nutrient speciation in ground-water samples collected from agricultural and urban areas in regional National Water-Quality Assessment Program study units in the arid to semiarid Western United States, 1993-2004. 


\section{Nutrient Detection Frequencies}

Reduced forms of nitrogen were the least-frequently detected nutrients (fig. $6 \mathrm{~A}$ ); only 15 to 30 percent of the samples had detectable concentrations of ammonia, Kjeldahl nitrogen, and nitrite. In 80 to 90 percent of the samples there were detectable concentrations of nitrate, total phosphorus, and orthophosphorus. To determine whether the data are biased by repeated collection of samples from some sites, repeat analyses from individual sites were deleted, leaving only the most recent sample collected. The greatest change was for ammonia, where removal of repeat analyses increased the detection frequency from 15 to 21 (fig. $6 B$ ).

The data in figure 6 have been recensored, and as such do not necessarily represent how frequently contaminants would be detected in a new sampling effort undertaken today in similar areas. Comparison of detection frequencies for nitrite, nitrate, total phosphorus, and orthophosphorus shows that values for recensored and non-recensored data are within a few percent of each other. For ammonia and Kjeldahl nitrogen, however, the differences are much greater. Prior to recensoring, ammonia and Kjeldahl nitrogen were detected in 42 and 52 percent of the samples, respectively. After recensoring, these nitrogen species were detected in only 15 and 29 percent of the samples, respectively.

Breakdown of the data by land-use classification shows that nitrite, nitrate, total phosphorus, and orthophosphorus are detected slightly more frequently in agricultural areas than in urban areas (fig. 7). Conversely, ammonia and Kjeldahl nitrogen are more frequently detected in urban settings than agricultural ones.

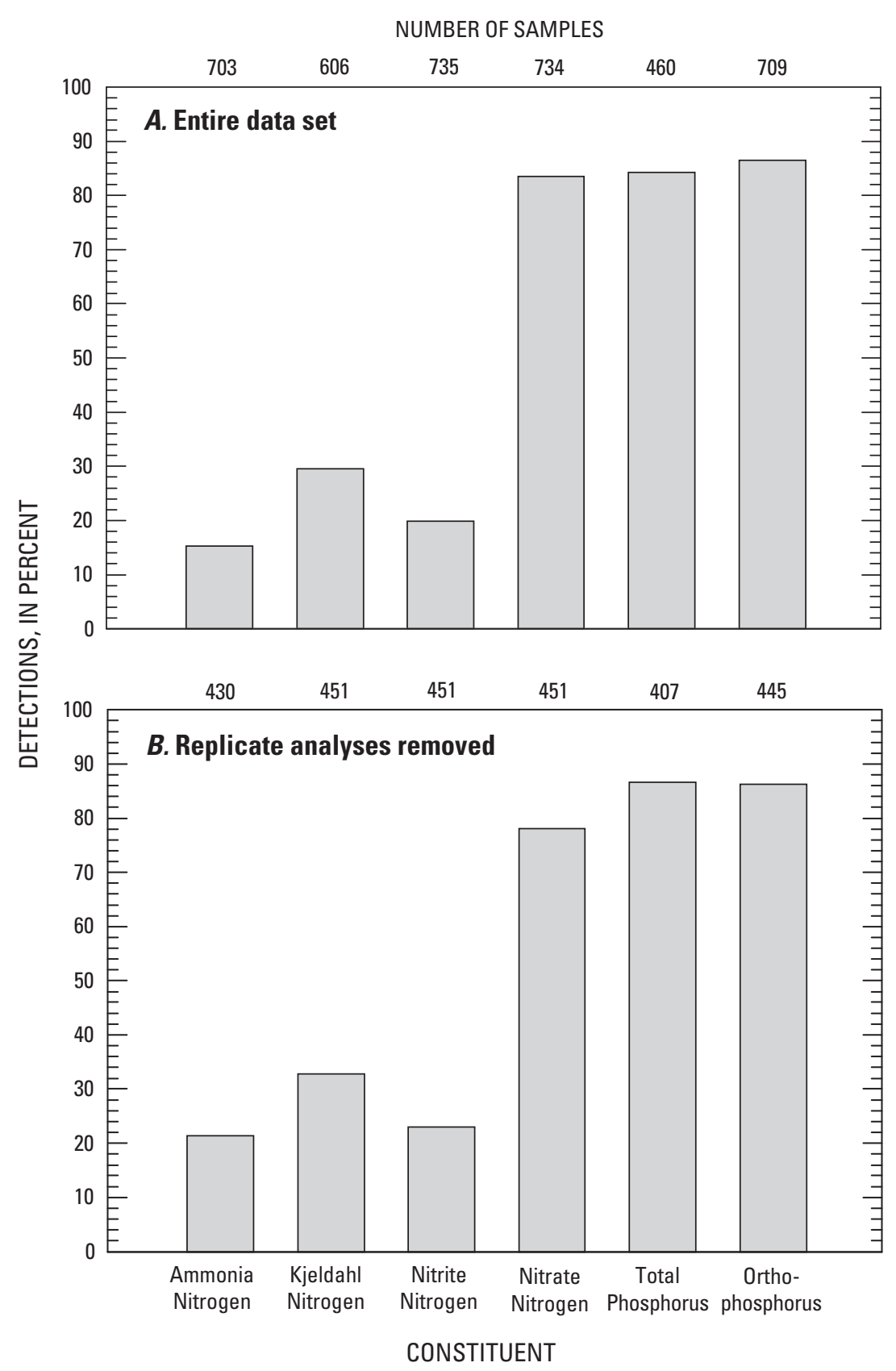

Figure 6. Percentage of nutrient detections following recensoring of nutrient datasets $(A)$ for entire dataset, and $(B)$ after removing replicate analyses, retaining only the most recent analysis at a given site, within regional National Water-Quality Assessment Program study units in the arid to semiarid Western United States, 1993-2004. 


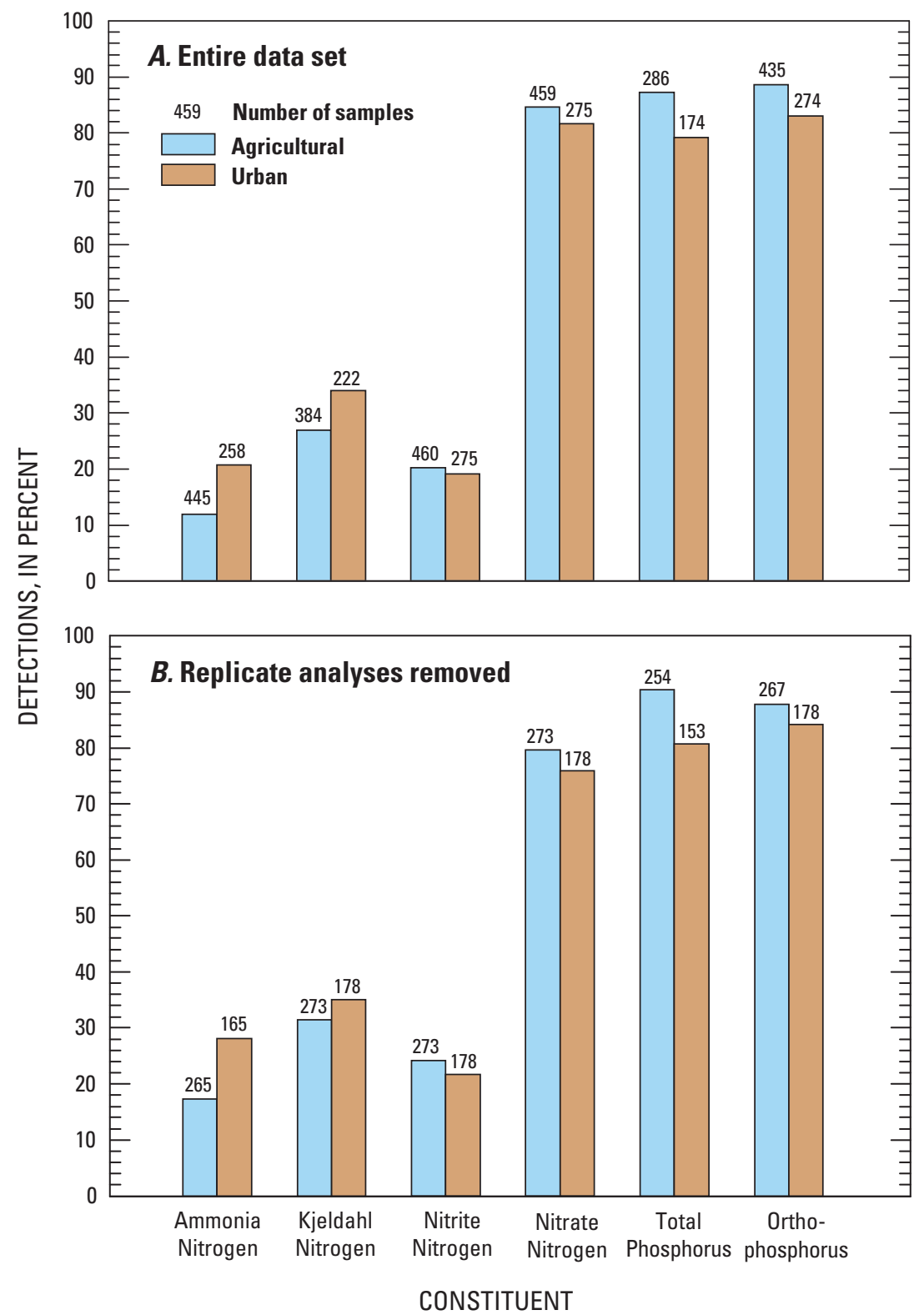

Figure 7. Effect of land use on the percentage of detections following recensoring of nutrient data sets $(A)$ for entire data set and $(B)$ after removing replicate analyses, retaining only the most recent analysis from a given site, within regional National Water-Quality Assessment Program study units in the arid to semiarid Western United States, 1993-2004. 


\section{Nutrient Concentrations}

The distribution of concentrations of nutrient species differs substantially among study units (fig. 8; table 5). Median nitrate concentrations within each study unit were below the USEPA MCL of $10 \mathrm{mg} / \mathrm{L}$ and varied substantially $(p<0.05)$. Median nitrite concentrations were below the NWQL LRL of $0.01 \mathrm{mg} / \mathrm{L}$ for all study units. Ammonia and Kjeldahl nitrogen were rarely detected in the CAZB, GRSL, SACR, and SANJ study units, for example, but were commonly detected in the NVBR, RIOG, and SOCA study units. In only one study unit, SOCA, were the median ammonia and Kjeldahl nitrogen concentrations greater than the NWQL LRL $(0.2 \mathrm{mg} / \mathrm{L})$.

In all study units, median orthophosphorus and totalphosphorus concentrations were less than $0.1 \mathrm{mg} / \mathrm{L}$ (fig. 8; table 5) and were determined to be significantly different among study units $(p<0.05)$. The greatest phosphorus concentrations, greater than $2 \mathrm{mg} / \mathrm{L}$, were measured in the NVBR and SANJ study units (fig. 8). Orthophosphorus concentration in nearly 10 percent of the samples from the NVBR study unit exceeded $1 \mathrm{mg} / \mathrm{L}$. Phosphorus concentrations were low in ground water because phosphorus typically binds to soil particles. Most of the NVBR agricultural samples are from the Fallon area, where ground water is commonly sulfate reducing and orthophosphorus is being released as iron and manganese oxyhydroxides dissolve (Seiler and others, 2005). Because of the relatively oxic nature of water from wells sampled from the SANJ, different processes are likely governing the occurrence of orthophosphorus in these systems.

With the exception of nitrite concentrations in urban land-use areas $(p=0.620)$, there were significant differences among study units with respect to nutrient concentrations in agricultural and urban areas (fig. $9, p<0.05$ ). Differences between agricultural and urban areas were examined in the three study units where both agricultural and urban samples were collected (NVBR, RIOG, and SACR). Comparison of land use in these study units indicates that there are differences in nutrient concentrations between agricultural and urban lands (fig. 9); however, the differences are inconsistent.

Table 5. Median concentration of nutrient species within regional National Water-Quality Assessment Program study units in the arid to semiarid Western United States, 1993-2004.

[Concentration for nitrogen species expressed as milligrams nitrogen per liter; orthophosphorus and total phosphorus concentrations expressed as milligrams phosphorus per liter. Abbreviations: CAZB, Central Arizona Basins; GRSL, Great Salt Lake Basins; NVBR, Nevada Basin and Range; RIOG, Rio Grande Valley; SACR, Sacramento River Basin; SANJ, San Joaquin-Tulare Basins; SOCA, Southern California Basins. Symbols: <, less than; -, not applicable]

\begin{tabular}{|c|c|c|c|c|c|c|c|c|}
\hline \multirow{2}{*}{ Nutrient species } & \multirow{2}{*}{ Land use } & \multicolumn{7}{|c|}{ Study units } \\
\hline & & CAZB & GRSL & NVBR & RIOG & SACR & SANJ & SOCA \\
\hline \multirow[t]{2}{*}{ Ammonia nitrogen } & Agricultural & $<0.04$ & - & 0.050 & $<0.04$ & $<0.04$ & $<0.04$ & - \\
\hline & Urban & - & $<0.04$ & $<0.04$ & 0.07 & $<0.04$ & - & 0.36 \\
\hline \multirow[t]{2}{*}{ Kjeldahl nitrogen } & Agricultural & $<0.2$ & - & 0.28 & 0.20 & $<0.2$ & $<0.2$ & - \\
\hline & Urban & - & $<0.2$ & $<0.2$ & $<0.20$ & $<0.2$ & - & 0.62 \\
\hline \multirow[t]{2}{*}{ Nitrite nitrogen } & Agricultural & $<0.01$ & - & $<0.01$ & $<0.01$ & $<0.01$ & $<0.01$ & - \\
\hline & Urban & - & $<0.01$ & $<0.01$ & $<0.01$ & $<0.01$ & - & $<0.01$ \\
\hline \multirow[t]{2}{*}{ Nitrate nitrogen } & Agricultural & 19.6 & - & $<0.1$ & 2.0 & 0.72 & 8.3 & - \\
\hline & Urban & - & 6.8 & 2.7 & $<0.1$ & 2.4 & - & $<0.1$ \\
\hline \multirow[t]{2}{*}{ Orthophosphorus } & Agricultural & $<0.02$ & - & 0.180 & 0.06 & 0.074 & 0.037 & - \\
\hline & Urban & - & 0.028 & 0.046 & 0.03 & 0.079 & - & 0.060 \\
\hline \multirow[t]{2}{*}{ Total phosphorus } & Agricultural & 0.015 & - & 0.150 & 0.06 & 0.064 & 0.040 & - \\
\hline & Urban & - & 0.032 & 0.021 & 0.03 & 0.113 & - & 0.053 \\
\hline
\end{tabular}




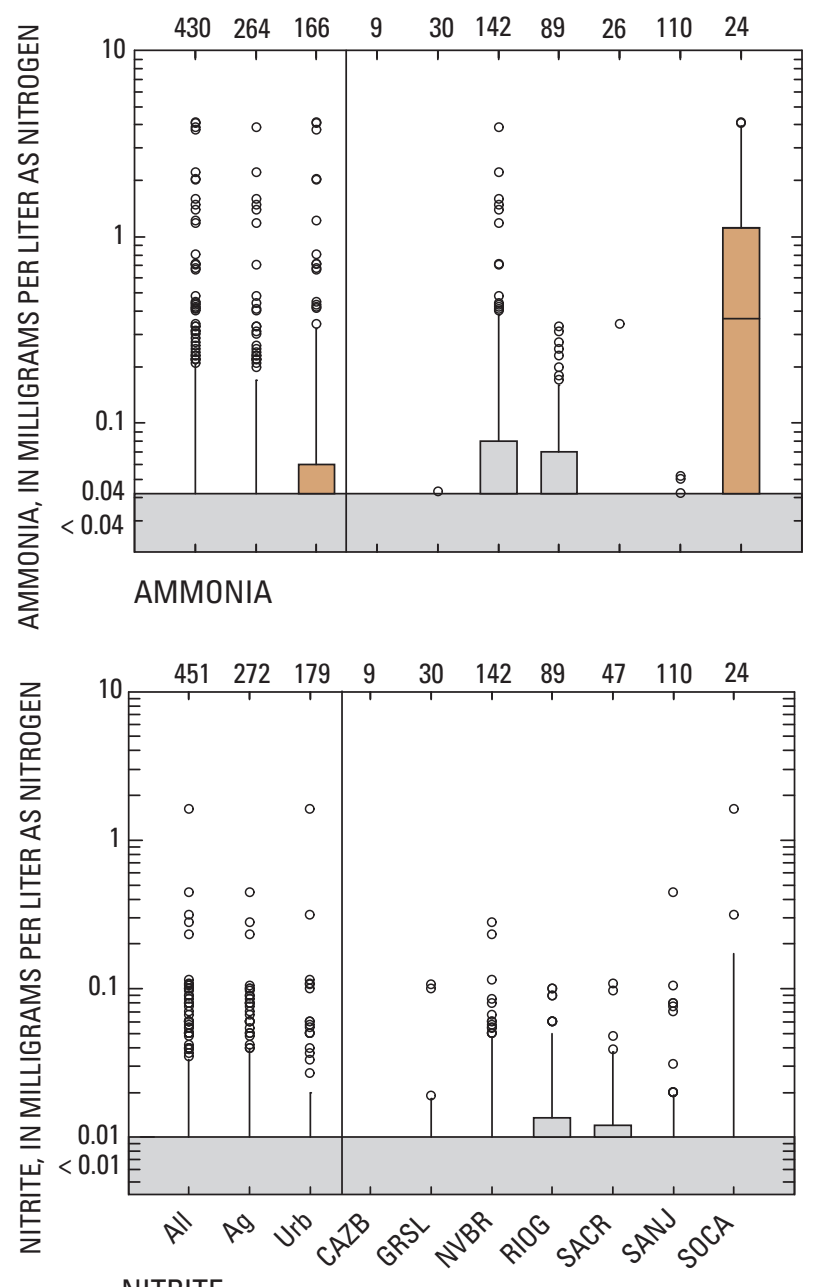

NITRITE
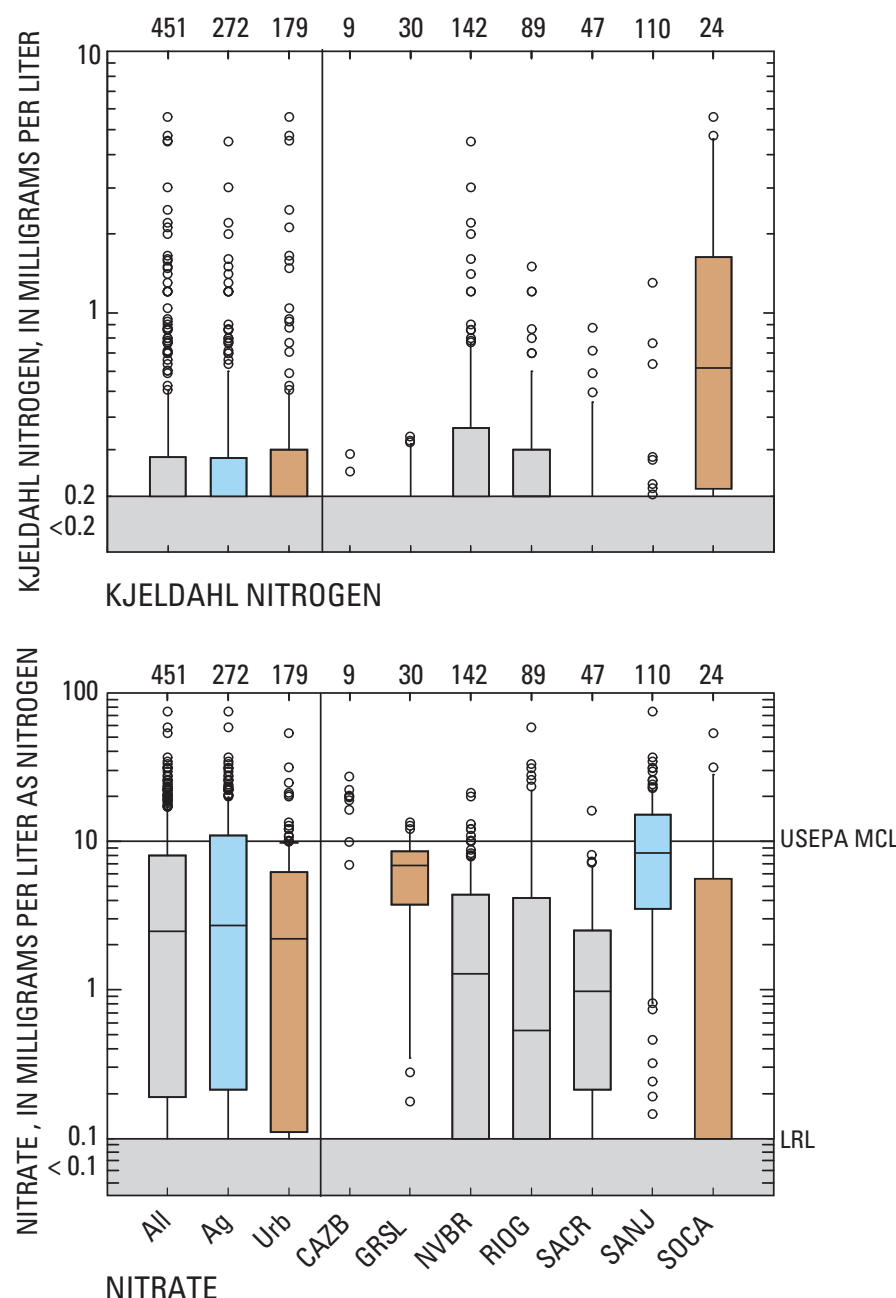

\section{EXPLANATION SCHEMATIC BOXPLOT}

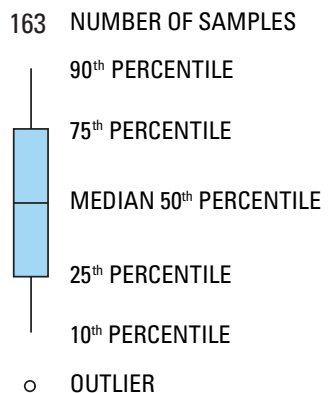

USEPA MCL-U.S. Environmental Protection Agency maximum contaminant level

LRL-National Water Quality Laboratory, laboratory reporting limit

All—Agricultural and Urban Land Use

Ag-Agricultural

Urb-Urban

Figure 8. Nutrient concentration in filtered ground-water samples collected from agricultural and urban areas within regional National Water-Quality Assessment Program study units in the arid to semiarid Western United States, 1993-2004. See figure 1 for definition of study unit abbreviations. 


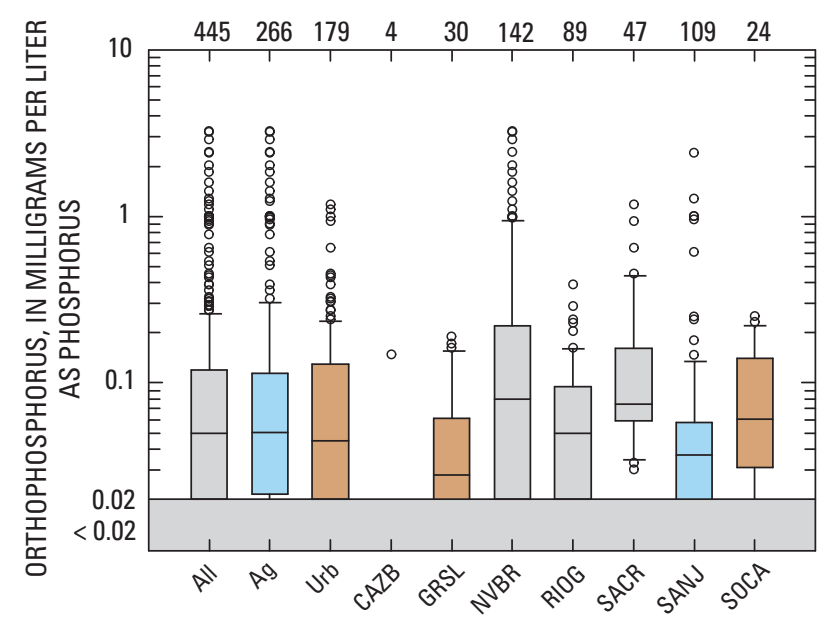

ORTHOPHOSPHORUS

\section{EXPLANATION}

SCHEMATIC BOXPLOT

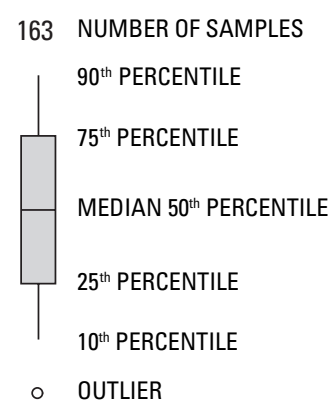

Figure 8.-Continued.

For nitrate, concentrations from agricultural sites were significantly greater than those from urban sites for the RIOG unit (fig. 9, $p<0.05$ ); however, the reverse was true for the NVBR $(p<0.05)$ and SACR units $(p=0.048)$. For ammonia and Kjeldahl nitrogen, concentrations from agricultural sites were significantly greater than those from urban sites for the NVBR study unit (fig. 9, $p<0.05$ ). Ammonia concentrations in the RIOG study unit were higher in urban samples $(p<$ $0.05)$ and Kjeldahl nitrogen was higher in agricultural areas $(p=0.016)$. Ammonia and Kjeldahl nitrogen concentrations were similar $(p>0.05)$ in agricultural and urban areas in the SACR study unit. For orthophosphorus and total phosphorus, concentrations from agricultural sites were significantly greater than those from urban sites for the NVBR study unit $(p<0.05)$. Although there appears to be slightly higher concentrations of these nutrients in agricultural areas than in urban areas within the RIOG study unit, the differences

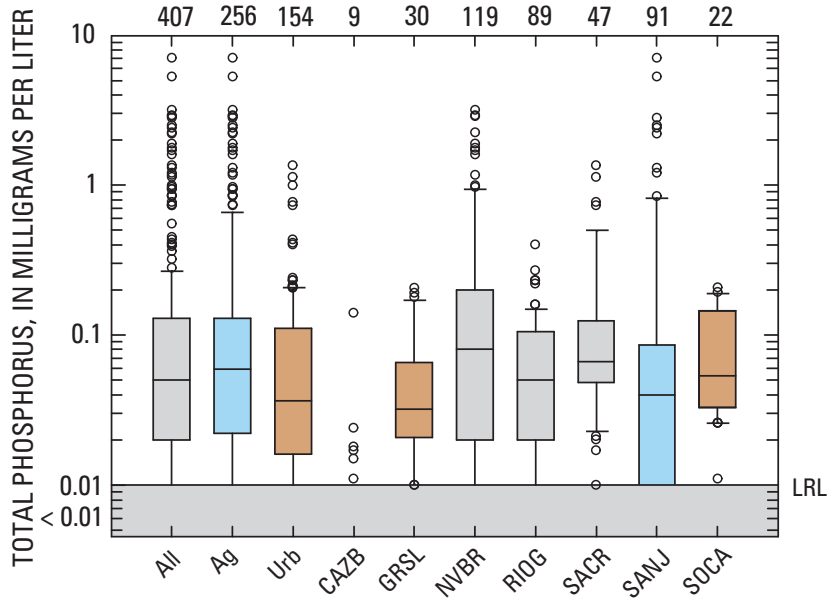

TOTAL PHOSPHORUS

LRL-National Water Quality Laboratory, laboratory reporting limit

All-Agricultural and Urban Land Use

Ag-Agricultural

Urb-Urban were not determined to be significant $(p>0.05)$. There were no statistical differences in median total phosphorus or orthophosphorus concentrations between the agricultural and urban areas in the SACR study unit $(p>0.05)$.

The distribution of nutrient concentrations among the study units probably results from differences in local area geochemistry, in particular ground-water redox conditions, rather than from differences in fertilizer application rate. Phosphorus adsorption and many of the reactions involving nitrogen are redox sensitive. Consider two areas in which initial nitrate concentrations are identical: the area with anaerobic ground water likely will have lower nitrate concentrations because of nitrogen loss through denitrification, which occurs only in anaerobic settings (table 6). Release of ammonia following oxidation of organic matter can increase ammonia concentrations in anaerobic settings because ammonia is not oxidized to nitrate. 

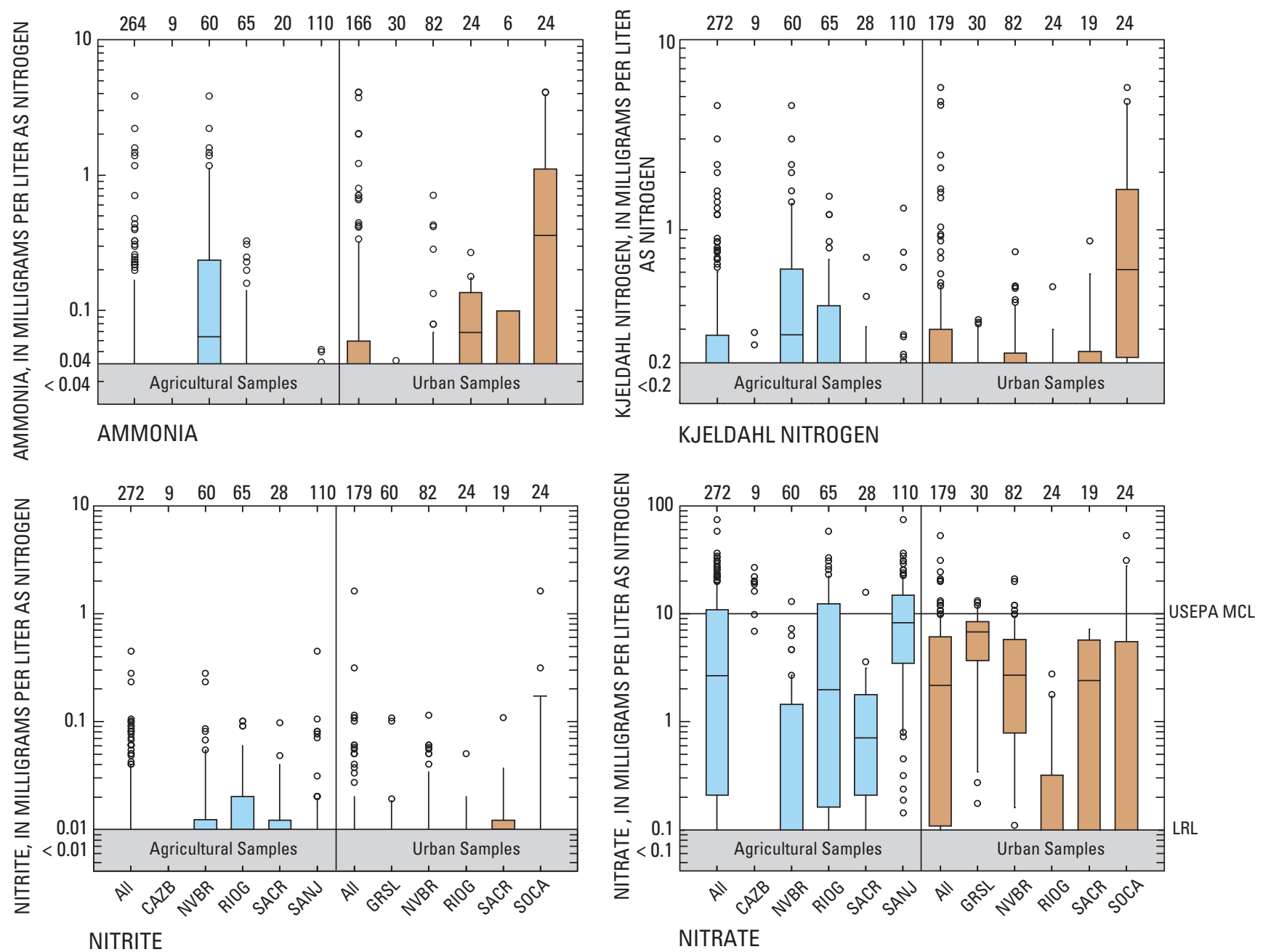

\section{EXPLANATION}

SCHEMATIC BOXPLOT

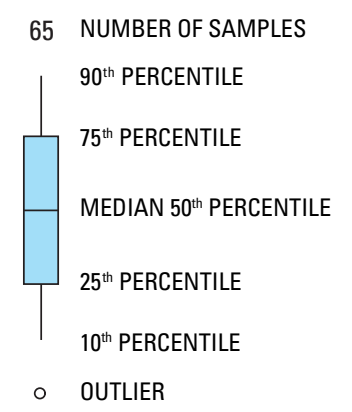

USEPA MCL-U.S. Environmental Protection Agency maximum contaminant level

LRL-National Water Quality Laboratory, laboratory reporting limit

All-All samples within the designated land use category after recensoring and removal of repeated analyses

Figure 9. Nutrient concentration in filtered ground-water samples collected from agricultural and urban areas within regional National Water-Quality Assessment Program study units in the arid to semiarid Western United States, 1993-2004. See figure 1 for definitions of study unit abbreviations. 


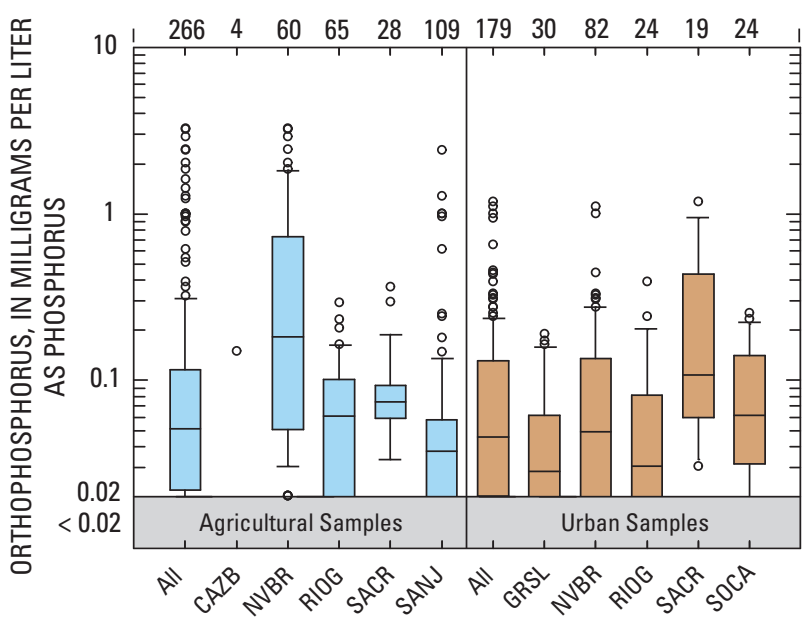

ORTHOPHOSPHORUS

\section{EXPLANATION}

SCHEMATIC BOXPLOT

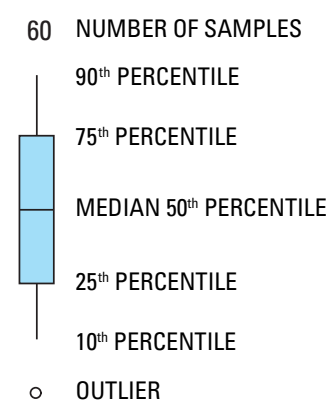

Figure 9.-Continued.

Table 6. Reactions sensitive to oxidation-reduction conditions that may influence nutrient concentrations in ground water.

[Abbreviations: $\mathrm{NH}_{3}$, ammonia; $\mathrm{NO}_{3}^{-}$, nitrate; $\mathrm{N}_{2}$, diatomic nitrogen; $\mathrm{OP}$, orthophosphorus; $\mathrm{MOOH}$, generic-metal oxyhydroxide; $\mathrm{M}^{+2}$, generic-divalentmetal species; Fe, iron; Mn, manganese]

\begin{tabular}{|c|c|}
\hline $\begin{array}{l}\text { Redox-sensitive } \\
\text { reaction }\end{array}$ & Comments \\
\hline$\frac{\text { Nitrification }}{\left(\mathrm{NH}_{3} \rightarrow \mathrm{NO}_{3}^{-}\right)}$ & Reaction only occurs in aerobic settings. \\
\hline$\frac{\text { Denitrification }}{\left(\mathrm{NO}_{3}{ }^{-} \rightarrow \mathrm{N}_{2}\right)}$ & Reaction only occurs in anaerobic settings. \\
\hline $\begin{array}{l}\frac{\text { Adsorption/Desorption }}{\mathrm{OP}-\mathrm{MOOH} \leftrightarrow} \\
\mathrm{OP}+\mathrm{M}^{+2}\end{array}$ & $\begin{array}{l}\text { Hydrous-metal (Fe and } \mathrm{Mn} \text { ) oxides can } \\
\text { dissolve under anaerobic conditions, } \\
\text { releasing adsorbed orthophosphorus. }\end{array}$ \\
\hline
\end{tabular}

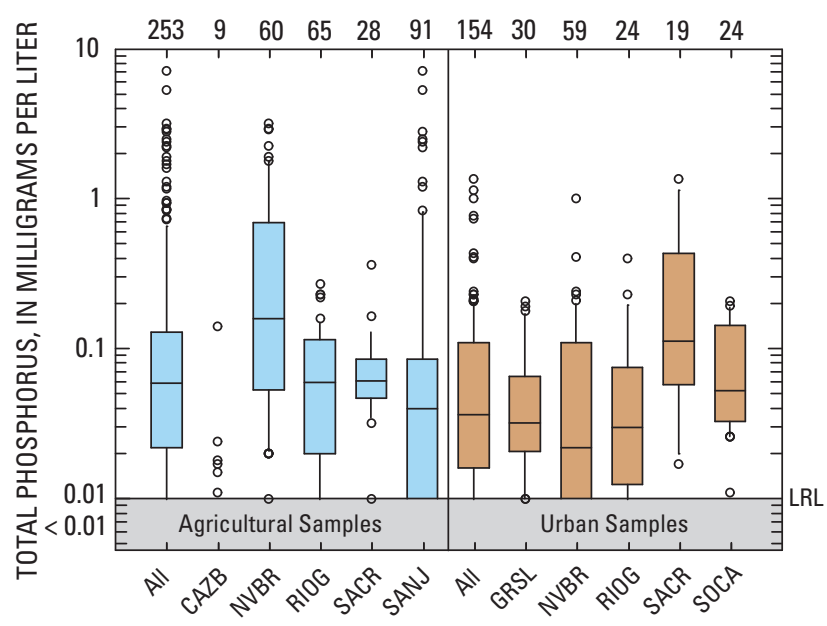

TOTAL PHOSPHORUS

LRL-National Water Quality Laboratory, laboratory reporting limit

All-All samples within the designated land use category after recensoring and removal of repeated analyses

\section{Nitrate}

The median nitrate concentration in samples collected from agricultural areas $(2.7 \mathrm{mg} / \mathrm{L})$ was higher $(p=0.02)$ than that in samples collected from urban areas $(2.2 \mathrm{mg} / \mathrm{L})$ (fig. 8). The interquartile ranges differ, with more than 25 percent of the samples in agricultural areas exceeding the MCL of $10 \mathrm{mg} / \mathrm{L}$ and less than 10 percent of the samples in urban areas exceeding the MCL. All study units had samples that contained nitrate concentrations exceeding the USEPA MCL of $10 \mathrm{mg} / \mathrm{L}$. The median nitrate concentration exceeded the USEPA MCL for nitrate only in the CAZB study unit, but was near the MCL in the GRSL and SANJ study units (fig. 8; table 5). In three study units, the maximum nitrate concentration exceeded $50 \mathrm{mg} / \mathrm{L}$. 
Comparisons were made of the median and upperquartile summary statistic between agricultural and urban areas. The data indicate that higher nitrate concentrations are more frequently observed in agricultural areas. The median of the upper-quartiles from agricultural areas $(12.5 \mathrm{mg} / \mathrm{L})$ is more than twice that of the urban areas $(5.8 \mathrm{mg} / \mathrm{L})$. Possible reasons that nitrate concentrations exceed the nitrate MCL more frequently in agricultural areas include greater application of nitrogen fertilizer (fig. 10A) and a greater number of houses using septic systems in agricultural areas (fig. 10B).

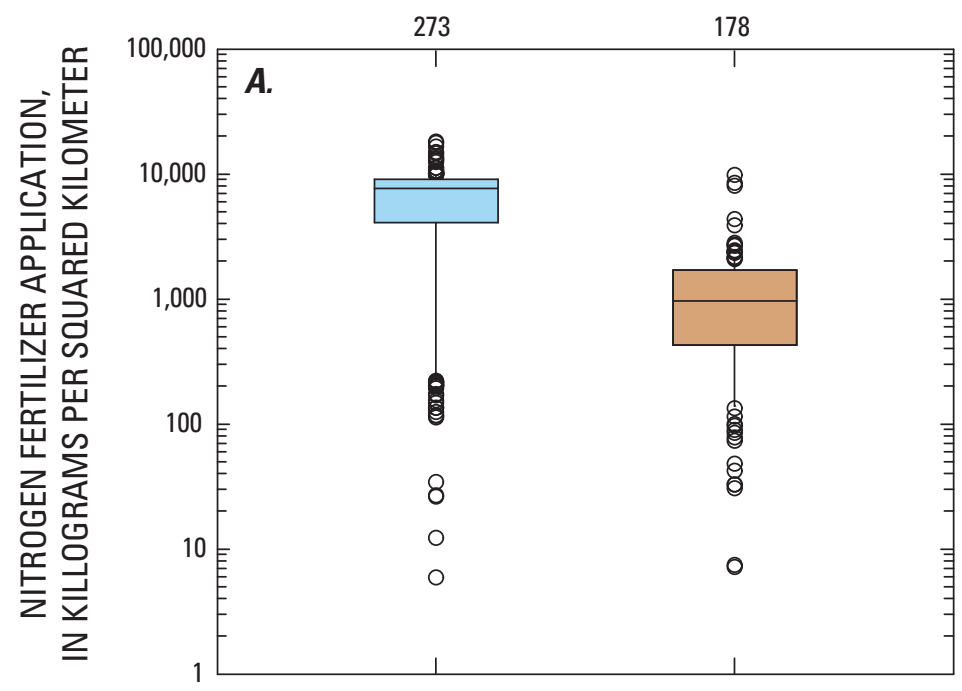

\section{EXPLANATION SCHEMATIC BOXPLOT}

272 NUMBER OF SAMPLES

90 $0^{\text {th }}$ PERCENTILE

$75^{\text {th }}$ PERCENTILE

MEDIAN 50"t PERCENTILE

$25^{\text {th }}$ PERCENTILE

$10^{\text {th PERCENTILE }}$

○ OUTLIER

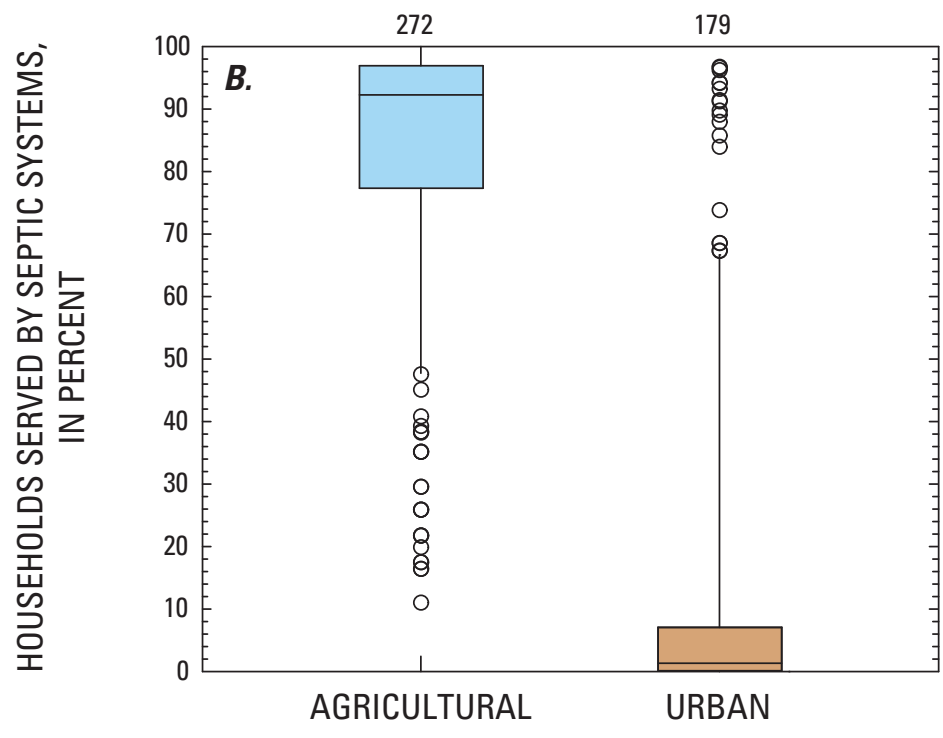

LAND USE

Figure 10. Relation between land use and $(A)$ application of nitrogen fertilizer and $(B)$ households served by septic systems within regional National Water-Quality Assessment Program study units in the arid to semiarid Western United States, 1993-2004. 
The differences in nutrient concentrations may be influenced by the number of samples collected from the individual study units. The effect on the summary statistics of unequal numbers of samples from the different study units is shown by comparing nitrate concentrations from the completely agricultural SANJ study unit with agricultural samples from all the other study units. The median nitrate concentration for all 273 agricultural samples in the data set is $2.7 \mathrm{mg} / \mathrm{L}$. If, however, the 110 agricultural samples from the SANJ study unit are removed, then the median concentration falls to only $0.7 \mathrm{mg} / \mathrm{L}$ (fig. 11). The sizeable effect of samples from the SANJ study unit on the combined summary statistics results from it having a statistical distribution greatly different from that of the remainder of the samples (median $8.3 \mathrm{mg} / \mathrm{L}$, fig. 11), and the large number of samples from the SANJ study unit. The difference in nitrate concentration in the SANJ study unit relative to other agricultural areas included in this investigation may partly be a result of greater agricultural intensity and aquifer characteristics. Agricultural fertilizer use within the SANJ study unit was similar to that in RIOG $(p=0.727)$, less than that in CAZB $(p<0.05)$, and higher than that in NVBR or SACR $(p<0.05)$. Samples from the SANJ study unit make up nearly 40 percent of all the agricultural samples. Similar skewing occurs with the other nutrient species but is not as pronounced because the statistical distributions of the sample groups are not as distinctly different.

Ground water at agricultural sites in the NVBR and SACR study units tends to be anoxic, with the median dissolved-oxygen concentration being less than $0.3 \mathrm{mg} / \mathrm{L}$ (fig. 4), whereas urban sites tend to be oxic, with the median dissolved-oxygen concentration exceeding $2 \mathrm{mg} / \mathrm{L}$ (fig. 4). The converse is true in the RIOG study unit, where agricultural sites tend to be more oxic than the urban sites (fig. 4). The effects of dissolved oxygen and fertilizer use on nitrate concentrations are shown in figure 12. Regardless of land use, the highest median nitrate concentrations occur in areas with the highest median dissolved-oxygen concentrations. The effect of fertilizer use on nitrate concentration is not as clearly defined as that for dissolved oxygen.

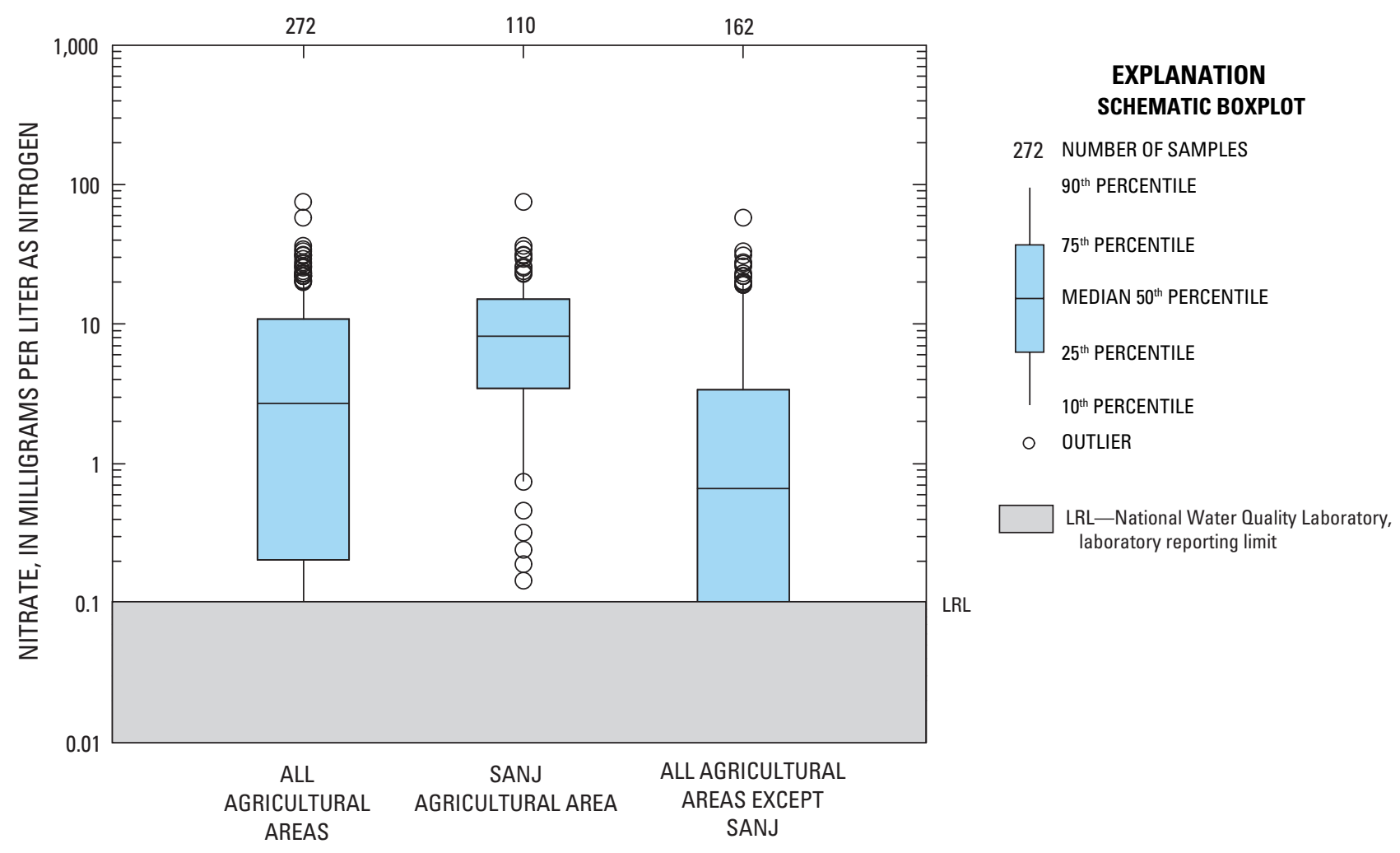

Figure 11. Nitrate concentration in water samples collected from all agricultural wells, agricultural wells in the San Joaquin-Tulare Basins (SANJ) study unit, and agricultural wells in the Central Arizona Basins (CAZB), Nevada Basin and Range (NVBR), Rio Grande Valley (RIOG), and Sacramento River Basin (SACR), 1993-2004. 


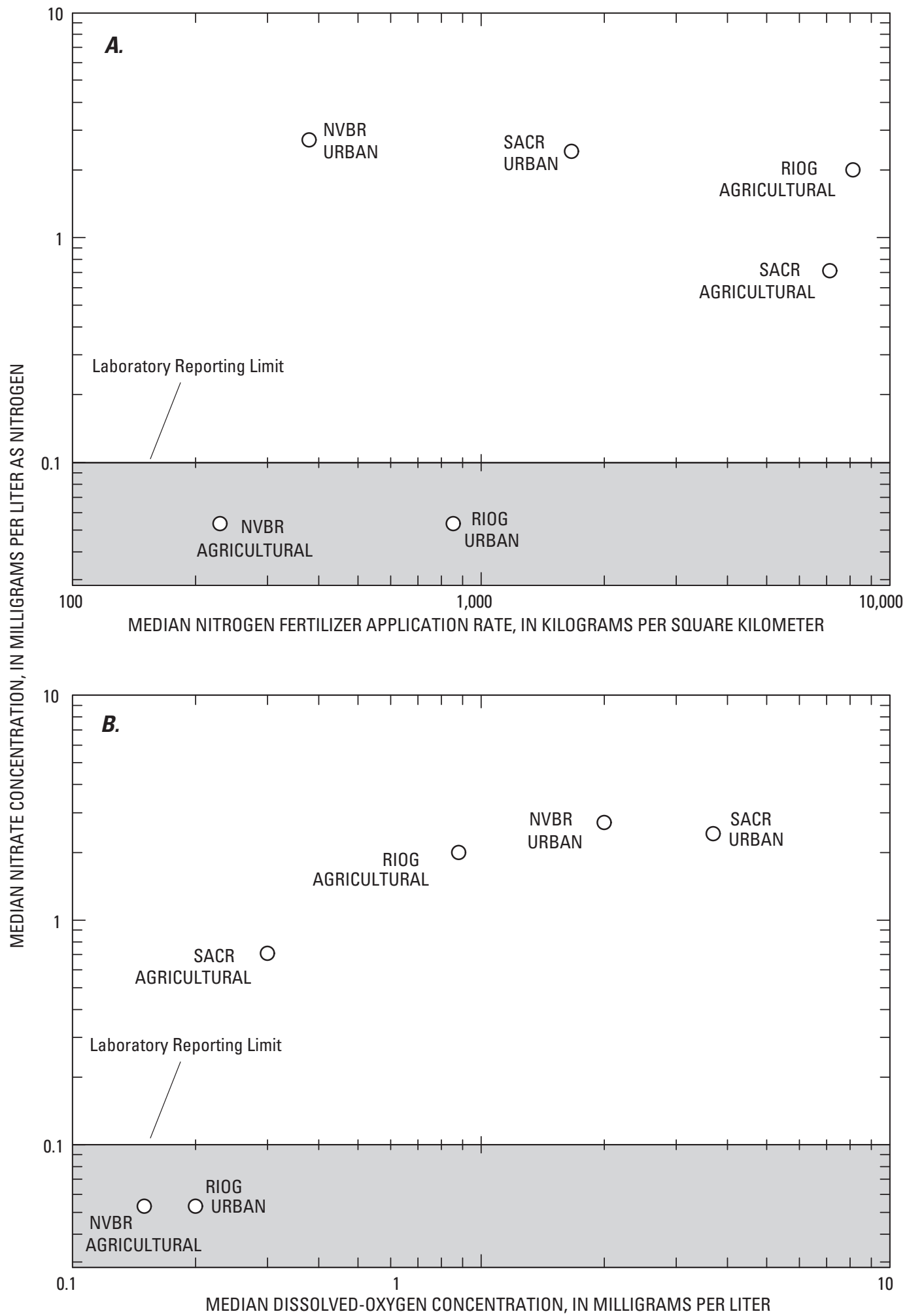

Figure 12. Relation between median nitrate concentration with $(A)$ median fertilizer application rate and $(B)$ median dissolved-oxygen concentration in agricultural and urban areas in the Nevada Basin and Range (NVBR), Rio Grande Valley (RIOG), and Sacramento River Basin (SACR), 1993-2004. 
Previous studies have shown that nitrate contamination is caused by complex interactions among nitrogen sources and aquifer characteristics (Nolan 2001, p. 298-299). Correlations between nutrient concentration and various factors such as well depth and aquifer and land-use characteristics (table 4) were computed using non-parametric univariate and multivariate methods. Nutrient concentrations were significantly correlated $(p<0.05)$ with some factors; however, the absolute value of the Spearman rho $(\rho)$ was generally less than 0.40 , indicating minimal correlation. Scatter plots showing univariate correlations between rankings of nitrate and selected well, aquifer, and land-use data for agricultural and urban wells are shown in figures 13 and $\underline{14}$, respectively. These plots are typical of the data and show that there is little predictability, even though statistically significant correlations may exist between the nutrient concentrations and the variables.

During univariate statistical analyses, where the $p$-value is less than 0.05 and the correlation coefficient is relatively high, care must be taken in interpreting the results. For example, one would expect a significant positive relation in agricultural areas between nitrate concentrations and the amount of fertilizer applied. This is observed in the data set when all of the study units are included, with the rank of nitrate concentration significantly increasing as the rank of fertilizer application increases (ig. 13). However, regression lines for individual study units on the plot show slightly negative relations for three study units, and slightly positive relations for the other two (fig. 15). The SACR and NVBR agricultural areas appear to dominate the lower end and the CAZB and SANJ agricultural data dominate the high end. Concentrations of all the nutrient species are affected by redox conditions ( $\underline{\text { table } 6}$ ), and an analysis of effects of well, aquifer, and land-use characteristics cannot be made without including differences in redox among the areas. Additionally, nitrate concentrations could be influenced by more than one environmental factor.

Multivariate-logistic regression was used to develop two models for predicting the probability that nitrate concentrations would exceed the USEPA nitrate MCL of $10 \mathrm{mg} / \mathrm{L}$ in agricultural areas. The two models were based on agricultural land use, with and without the SANJ nitrate data. Similar models for predicting exceedances in urban areas could not be developed because no significant explanatory factors could be elucidated.

These logistic regression models are intended to show the relation among relevant environmental and anthropogenic factors influencing the occurrence of nitrate above the USEPA MCL in ground water underlying agricultural areas within the arid and semiarid Western United States. Model coefficients will change in relation to irrigation practices, fertilizer use, aquifer redox conditions, and, in some cases, soil characteristics.

The general logistic model is described by Hosmer and Lemeshow (1989) and by Rupert (2003). The general form of the logistic-regression equation is, $P=\left[\left(e^{x}\right) /\left(1+e^{x}\right)\right]$, where
" $e$ " denotes the exponential function, $x$, that contains the significant explanatory variables $\left(V_{n}\right) . P$ is the probability of exceeding the USEPA MCL for nitrate. Using nitrate data from all agricultural areas, excluding SANJ, the probability of exceeding the USEPA standard can be estimated by $P=\left[\left(e^{x}\right) /\left(1+e^{x}\right)\right]$,

where

$$
\mathrm{x}=\left[-3.604+0.250\left(V_{1}\right)+0.849\left(V_{2}\right)-0.259\left(V_{3}\right)\right],
$$

and

$V_{1}$ is the amount of applied fertilizer, in tons $/ \mathrm{km}^{2}$,

$V_{2}$ is the area irrigated by sprinkler irrigation system(s), $\mathrm{km}^{2 *} 10$, and

$V_{3}$ is the iron concentration, $\mu \mathrm{g} / \mathrm{L}$.

The probability of exceeding the MCL can be estimated by using all available data from agricultural areas within the regional-study area, including SANJ, using, $P=\left[\left(e^{x}\right) /\left(1+e^{x}\right)\right]$,

where

$$
\begin{gathered}
x=\left[-4.040+0.227\left(V_{1}\right)+0.387\left(V_{2}\right)\right. \\
\left.-0.077\left(V_{3}\right)+0.023\left(V_{4}\right)\right]
\end{gathered}
$$

and

$$
\begin{aligned}
& V_{1}, V_{2} \text {, and } V_{3} \text {, are as described above, and } \\
& V_{4} \text { are the percentage of sand in the soil } \\
& \text { within the 500-meter buffer zone } \\
& \text { around the well. }
\end{aligned}
$$

Generally, the probability of exceeding the USEPA MCL for nitrate is influenced by the interaction of three key parameters: irrigated area, amount of fertilizer applied, and redox condition of the aquifer. Flood- and sprinklerirrigation practices were examined during the development of the nitrate MCL exceedance models in this study. Although flood irrigation had a negative effect on the occurrence of nitrate above the MCL, it was not a significant explanatory variable within either agricultural model (equation 1, $p=$ 0.09 ; equation $2, p=0.19$ ). Therefore, flood irrigation was not included in either model. Alternatively, in equation 1 (the model excluding SANJ data) the addition of sprinkler irrigation was highly significant $(p=0.001)$ and significantly improved the strength of the model $(p<0.05)$. However, within the second model (equation 2), sprinkler irrigation was marginally significant at the 95-percent confidence level $(p=0.062)$ and only slightly improved the overall strength of the model $(p=0.06)$. Although sprinkler irrigation was marginally significant in the second model, because of the significance of this parameter in equation 1 and because it had the greatest positive influence on nitrate concentrations above the MCL in both models, sprinkler irrigation was retained in both models. 

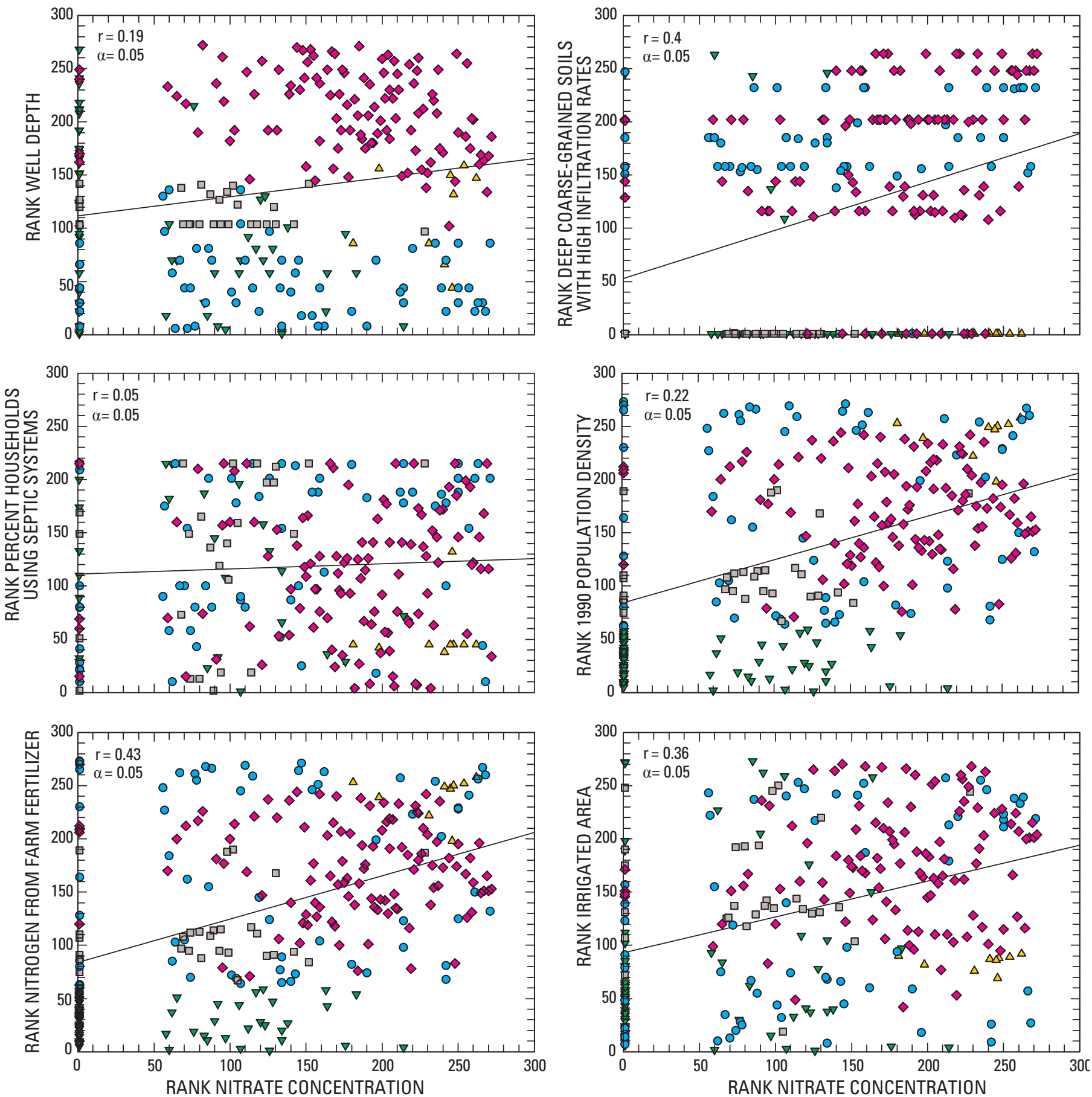

\section{EXPLANATION}

$\begin{array}{ll} & \text { Linear Regression Line } \\ \Delta & \text { CAZB } \\ \nabla & \text { NVBR } \\ \diamond & \text { RIOG } \\ \square & \text { SACR } \\ \diamond & \text { SANJ }\end{array}$

Figure 13. Relation between ranked nitrate concentrations and ranked well, aquifer, and land-use characteristics in agricultural areas within regional National Water-Quality Assessment Program study units in the arid to semiarid Western United States, 1993-2004. See figure 1 for definitions of study unit abbreviations. 

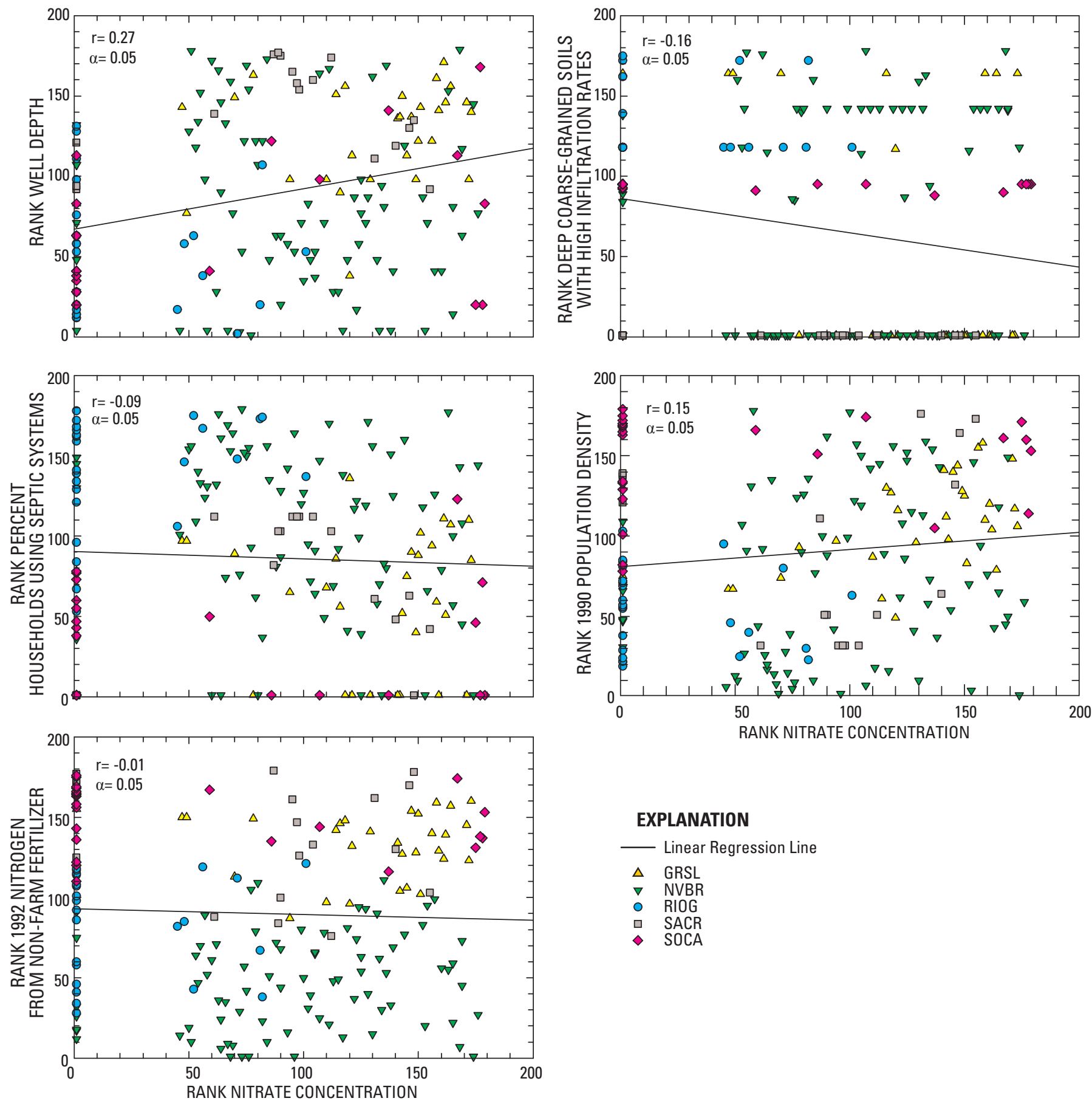

\section{EXPLANATION}

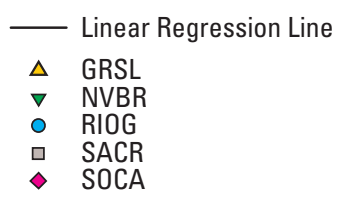

Figure 14. Relation between ranked nitrate concentrations and ranked well, aquifer, and land-use characteristics in urban areas within regional National Water-Quality Assessment Program study units in the arid to semiarid Western United States, 1993-2004. See figure 1 for definitions of study unit abbreviations. 


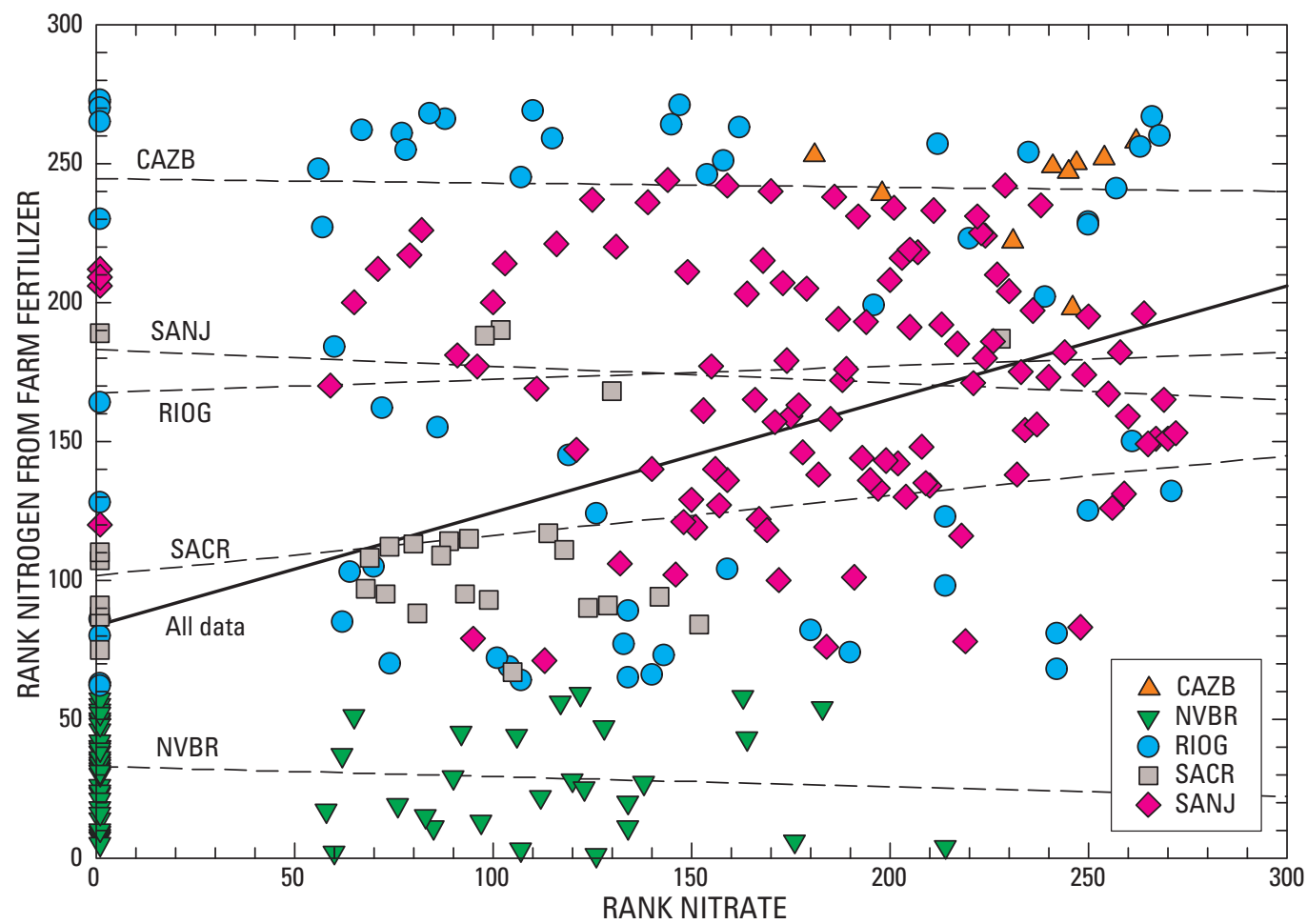

Figure 15. Relation between ranked nitrate concentrations and ranked nitrogen application rates in agricultural areas within in regional National Water-Quality Assessment Program study units in the arid to semiarid Western United States, 1993-2004.

Fertilizer-application data were available on a countyscale basis and extrapolated into the 500-meter buffer area around each of the wells. Within each model, fertilizer application showed a similar positive relation to the occurrence of nitrate exceeding the MCL $(p<0.05)$. Although the addition of percent sand did not significantly influence the exceedance of the nitrate MCL in the first model (equation 1, $p=0.092)$, sand did affect MCL exceedance in the second model $(p=0.031)$.

Although dissolved oxygen was not determined to be a significant explanatory variable in the logistic-regression models, dissolved-iron concentrations are influenced by the redox condition within the well (fig. 16). Under anaerobic and reducing conditions, iron oxides undergo reductive dissolution whereby iron is released into surrounding ground water.
Other studies have used the relation between redox-sensitive elements, such as iron, to develop redox models (Suzanne Paschke, U.S. Geological Survey, written commun., 2006). Redox condition, as evidenced by iron concentration, showed a negative influence on the exceedance of the nitrate MCL in both models $(p<0.05)$.

Although naturally occurring nitrate may play a role in the elevated nitrate concentrations observed in the shallow ground-water samples discussed in this report, at least some of the differences in nutrient concentrations among study units and between agricultural and urban land use likely results from differences in and interactions among ground-water redox condition, fertilizer application rates, and irrigation practices (table 7). 


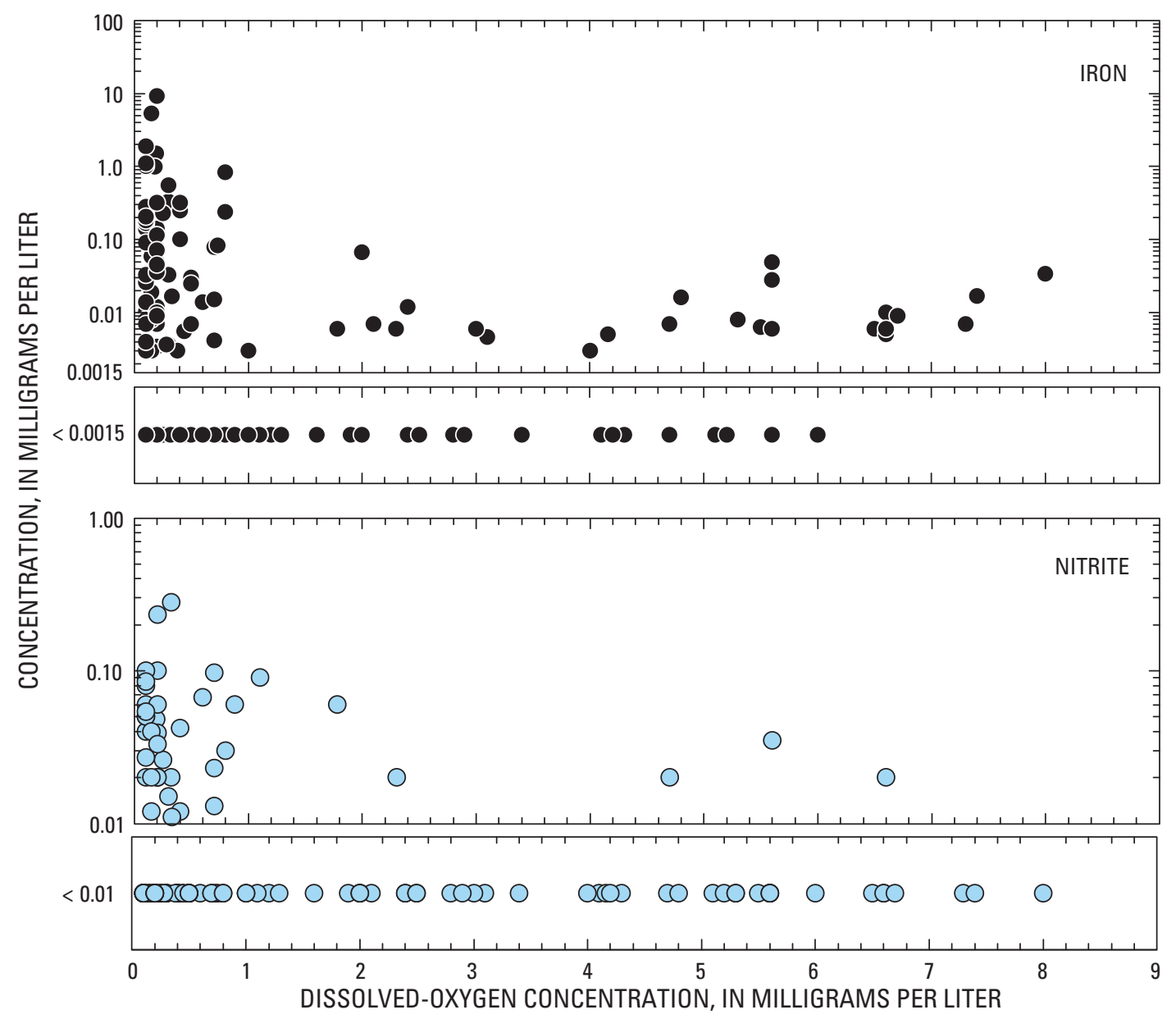

Figure 16. Relation among iron, nitrite, and dissolved-oxygen concentrations in ground-water samples collected from agricultural areas within regional National Water-Quality Assessment Program study units in the arid to semiarid Western United States, 1993-2004.

Table 7. Nitrate occurrence in shallow ground water beneath agricultural and urban areas within regional National Water-Quality Assessment Program study units in the arid to semiarid Western United States, 1993-2004.

[Abbreviations: LRL, laboratory reporting limit; MCL, maximum contaminant level; USEPA, U.S. Environmental Protection Agency; mg/L, milligram per liter. Symbol: <, less than]

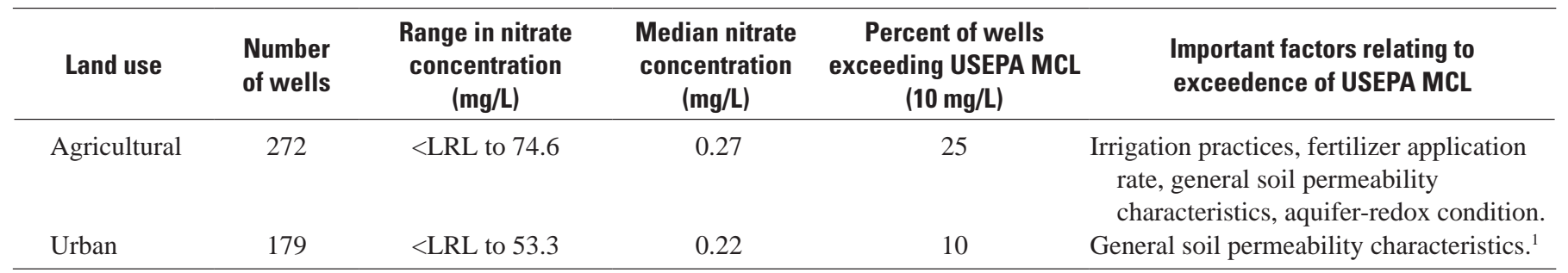

${ }^{1}$ A sufficiently strong predictive model could not be developed for the exceedence of the nitrate MCL in urban areas. The only variable that provided any significant contribution was soil hydrologic group $(p=0.044)$. 


\section{Pesticides}

All pesticide concentrations were below the USEPA MCLs for atrazine ( $3 \mu \mathrm{g} / \mathrm{L})$, simazine $(4 \mu \mathrm{g} / \mathrm{L})$, and dinoseb $(7 \mu \mathrm{g} / \mathrm{L})$. MCLs have not been promulgated by USEPA for other pesticides discussed in this section, but all concentrations were less than $8 \mu \mathrm{g} / \mathrm{L}$, and were commonly less than $1 \mu \mathrm{g} / \mathrm{L}$.

The most commonly detected pesticides in ground water belonged to the triazine, urea, amide, and carbamate classes. Predominant in ground water beneath both agricultural and urban areas were the triazine herbicides (fig. 17). Of the water samples collected from the 272 agricultural and 176 urban wells examined, 38 and 43 percent, respectively, contained detectable amounts of at least one triazine herbicide. Although water from urban wells showed a slightly higher detection frequency than water from agricultural wells for triazine herbicides, the difference was not significant (fig. 17, $p=0.215$ ). The next most commonly detected pesticides were the urea herbicides, which were detected in water from 12 percent of the agricultural wells and 7 percent of the urban wells. Detection frequency for none of the other pesticides exceeded 10 percent. Because of relatively low detection frequencies of different pesticides and varying pesticide-use patterns, correlations between pesticide detection frequencies and the ancillary data could be made only for the triazine, urea, and metolachlor pesticides. The relation between detection frequency of these particular pesticides and the ancillary data is described below.

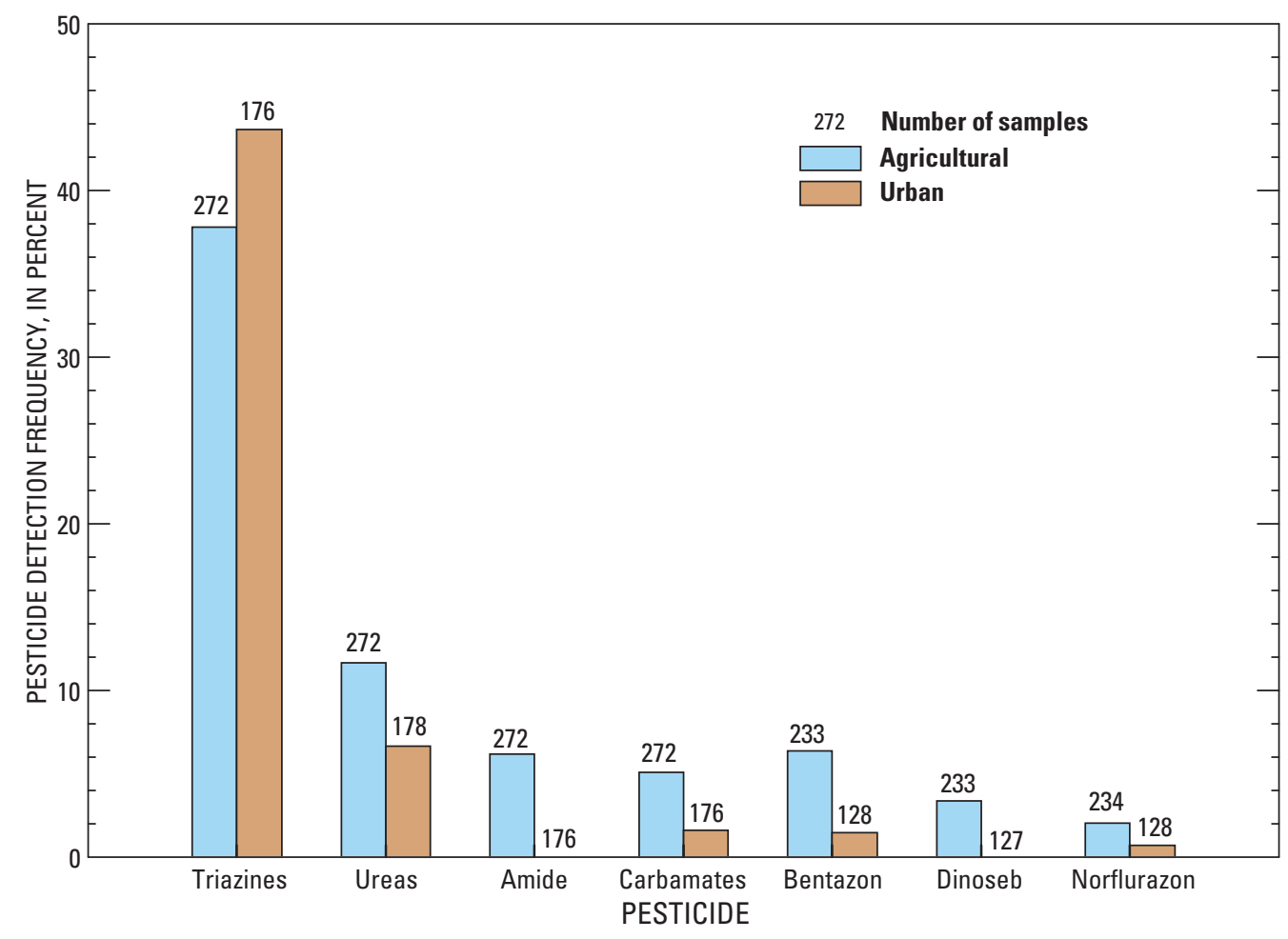

Figure 17. Pesticide detection frequency in ground-water samples collected from agricultural and urban areas within regional National Water-Quality Assessment Program study units in the arid to semiarid Western United States, 1993-2004. 


\section{Triazines}

Simazine is used on a wide variety of crop types including corn, citrus, and vineyards (Gilliom and others, 2006) and, in addition to agricultural use, simazine also is used as a nonselective herbicide in industrial areas (Extoxnet, 1993a). Simazine was detected in water from 28 percent of the wells in agricultural areas and 17 percent of the urban wells (fig. 18). The difference in detection frequency between the two land uses was significant $(p=0.010)$. Simazine was detected in at least one ground-water sample collected from each of the agricultural areas. Concentrations in water from agricultural wells ranged from less than detection to $0.230 \mu \mathrm{g} / \mathrm{L}$, and concentrations in water from urban areas ranged from less than detection to $0.051 \mu \mathrm{g} / \mathrm{L}$ (table 8). Univariate statistical analysis used to examine the relation between the ancillary data (table 4) and simazine detection frequency did not show strong correlations. However, by using nonparametric multivariate logistic regression, simazine showed stronger correlation with agricultural than urban land use, and within the agricultural model dissolved oxygen, temperature, depth to screened interval, and percent row crop were important explanatory variables (table 8). A strong model could not be made by using the urban dataset; however, general soil permeability characteristics within the buffer area around the well were determined to be important within the urban land-use setting (table 8).

Atrazine, a restricted-use herbicide, was detected in water from 16 and 24 percent of agricultural and urban wells, respectively (fig. 18). The difference in detection frequency of atrazine within the agricultural and urban land-use settings was significant $(p=0.031)$. Nationally, atrazine is ranked number one in agricultural use and is associated with the cultivation of corn (Gilliom and others, 2006). In addition to agricultural uses, atrazine is also used as a nonselective herbicide in industrial areas (Extoxnet, 1993b). Atrazine was detected in at least one well in four of the five agricultural areas (CAZB, NVBR, SACR, SANJ) and in at least one well in all the urban areas. Concentrations ranged from less than detection to $1.2 \mu \mathrm{g} / \mathrm{L}$ in agricultural areas and from less than detection to $1.58 \mu \mathrm{g} / \mathrm{L}$ in urban areas (table 8 ). Atrazine detection frequency was evaluated for correlation with the ancillary data by using multivariate-logistic regression.

Generally, detection of atrazine in urban areas was correlated with dissolved oxygen, temperature, permeability of aquifer materials, and percentage of households using public-sewer systems $(p<0.05$; table 8$)$. A strong agricultural model could not be developed but temperature and permeability of aquifer materials were important factors in agricultural areas $(p<0.05$; table 8$)$.

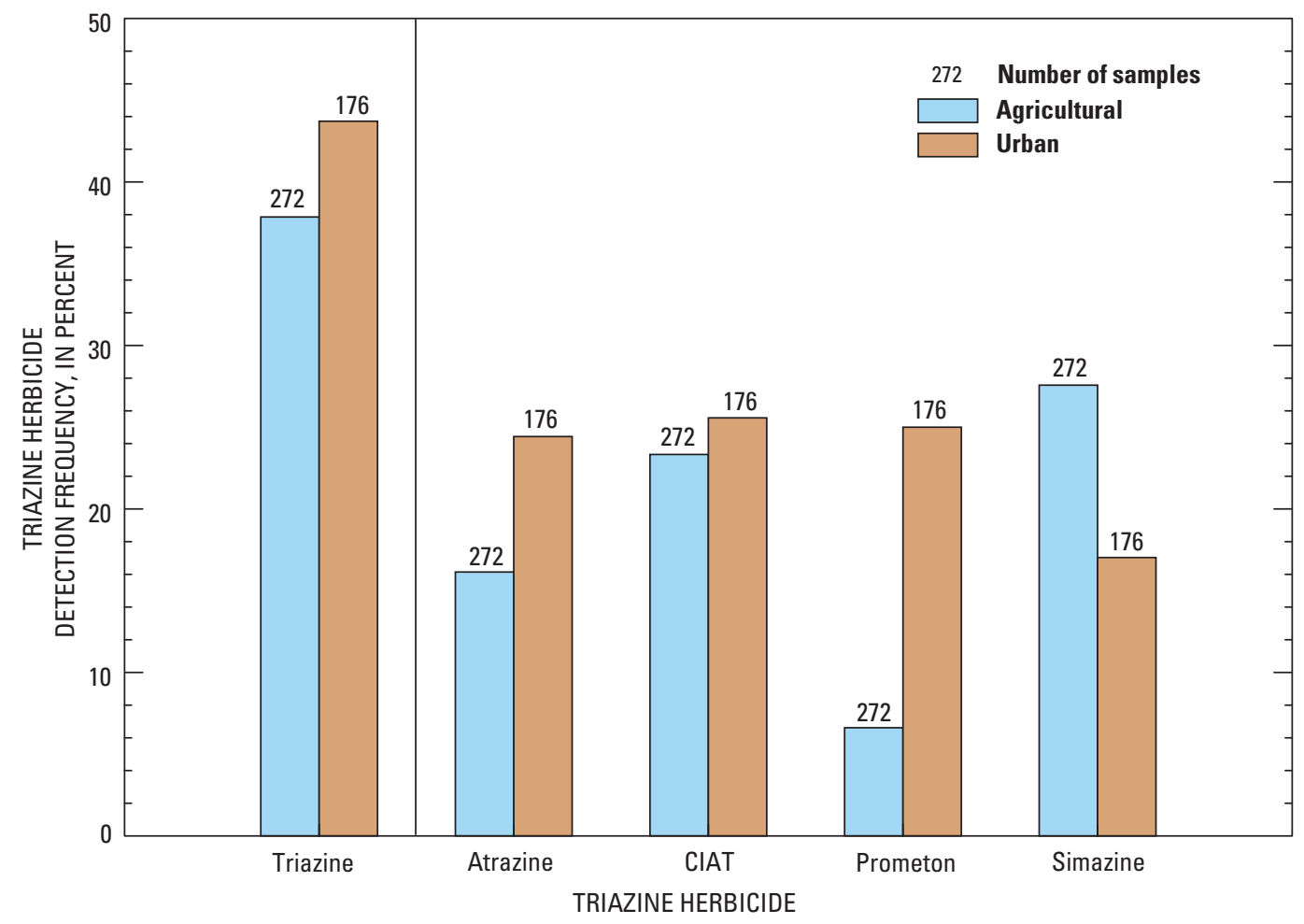

Figure 18. Triazine herbicide detection frequency in ground-water samples collected from agricultural and urban areas within regional National Water-Quality Assessment Program study units in the arid to semiarid Western United States, 1993-2004. 
Table 8. Pesticide occurrence in shallow ground water beneath agricultural and urban areas within regional National Water-Quality Assessment Program study units in the arid to semiarid Western United States, 1993-2004.

[Concentration range: With the exception of EPTC, pesticides listed in this table where concentrations were reported as estimated were included in the data analyses within this report. There were no estimated concentrations of EPTC. Factors relating to pesticide detection: All parameters for 500-meter buffer zone around wells. The "+" and "_" signs indicate a positive or negative correlation, respectively, of pesticide occurrence to designated explanatory variable. Abbreviations: LT-MDL, long-term method detection level; MCL, maximum contaminant level; SACR, Sacramento River Basin; SANJ, San Joaquin-Tulare Basins; USEPA, U.S. Environmental Protection Agency; nd, not determined; $\mu \mathrm{g} / \mathrm{L}$, microgram per liter. Symbol: <, less than]

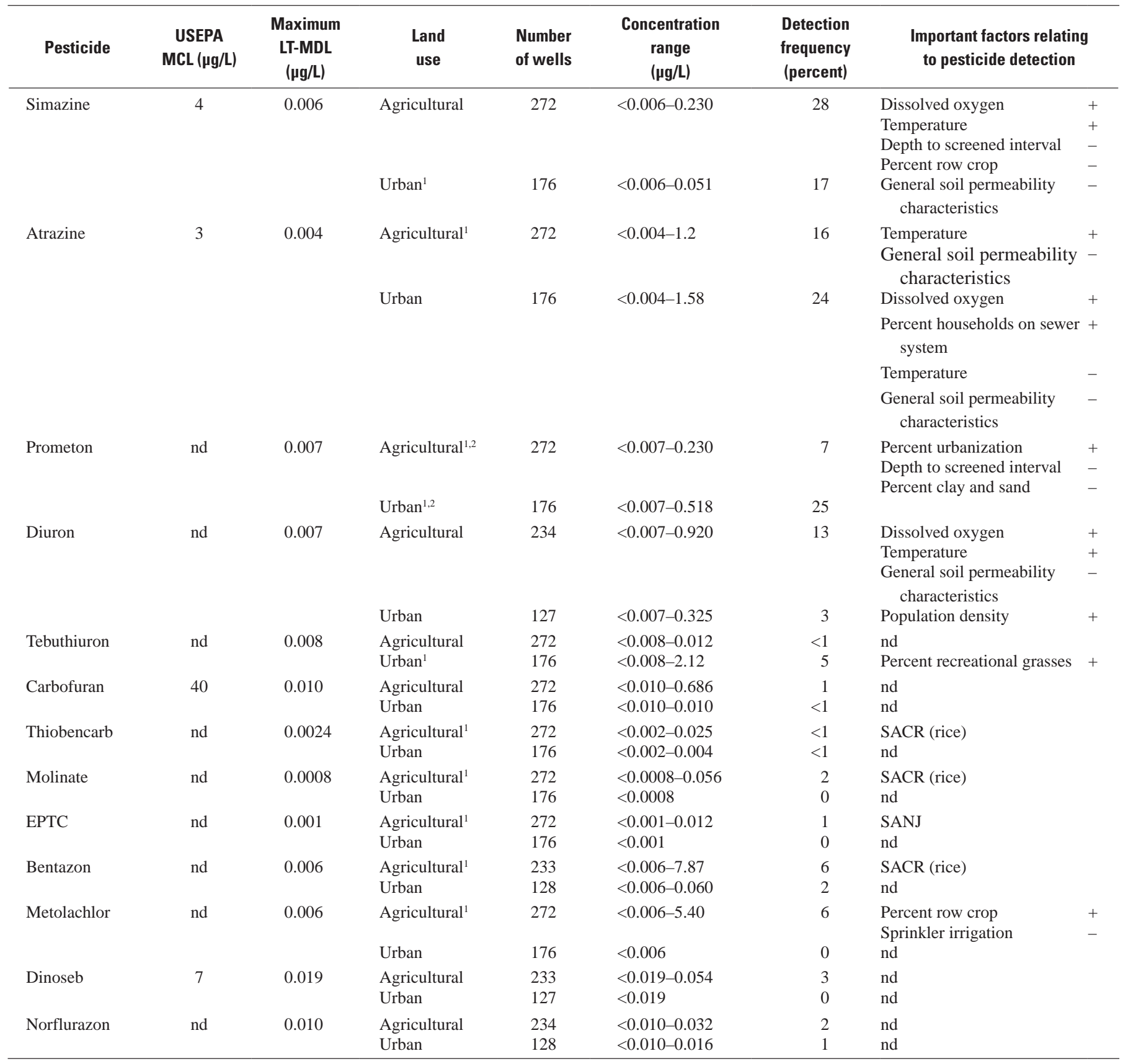

${ }^{1}$ A sufficiently strong logistic-regression model was not developed for this pesticide within areas of this land use. However, the parameters listed were determined to be important in the occurrence of the pesticide $(p<0.05)$.

${ }^{2}$ The logistic-regression model was analyzed for a combined dataset using both agricultural and urban land-use data. 
The degradation product of atrazine, deethylatrazine (CIAT), is more stable under oxic conditions than is atrazine (Barbash, 2003). Detectable concentrations of CIAT were measured in water from both agricultural (less than detection to $0.088 \mu \mathrm{g} / \mathrm{L}$ ) and urban (less than detection to $0.320 \mu \mathrm{g} / \mathrm{L}$ ) wells. Evaluation of the relation between atrazine, CIAT, and dissolved oxygen showed that the differences in detection frequency between these two compounds were not significantly different $(p \geq 0.10)$ at either the low $(<0.5 \mathrm{mg} / \mathrm{L})$ or high $(>4.0 \mathrm{mg} / \mathrm{L})$ range of dissolved oxygen (fig. 19A, $\underline{B}$ ). The number of wells represented within the low and high dissolved-oxygen categories for each of the two land-use settings was similar (fig. 19C). The difference between the detection of atrazine in agricultural samples within the low-oxygen category and high-oxygen category was not significantly different $(p=0.236)$. However, the detection frequency of CIAT was significantly higher in samples in the high dissolvedoxygen range than in the low dissolved-oxygen range in both agricultural $(p=0.003)$ and urban $(p<0.05)$ wells. Atrazine detection frequency in ground-water samples from urban areas also was determined to be significantly higher in the higher dissolved-oxygen category when compared to the lower dissolved-oxygen category $(p<0.05)$. Although the data indicate that atrazine is being degraded into CIAT, there is insufficient evidence to show whether this degradation is significantly influencing the detection frequency of atrazine within these land-use settings.

Prometon was detected more frequently in urban ground-water samples than in agricultural samples. This herbicide was detected in water from 25 percent of the urban (range less than detection to $0.518 \mu \mathrm{g} / \mathrm{L}$ ) and 7 percent of the agricultural (range less than detection to $0.230 \mu \mathrm{g} / \mathrm{L}$, table 8) wells, (fig. 18). Prometon was detected in four of the five urban areas (GRSL, NVBR, RIOG, SOCA) and was detected in at least one agricultural well from four of the five agricultural areas (CAZB, NVBR, RIOG, SANJ). Although there are no known prometon on crops, prometon is used to control weeds near fences, buildings, and rights-of-way in agricultural areas (Gilliom and others, 2006). Although separate multivariate logistic-regression models could not be developed for the occurrence of prometon, a general model considering all agricultural and urban land-use data was produced. The detection frequency of prometon was associated predominantly with percent urban land use, depth-toscreened interval, and average percent clay and sand in the soil within the buffer area $(p<0.05$; table 8). Unlike the other triazine herbicides, dissolved oxygen was not determined to be a significant explanatory variable in its detection.
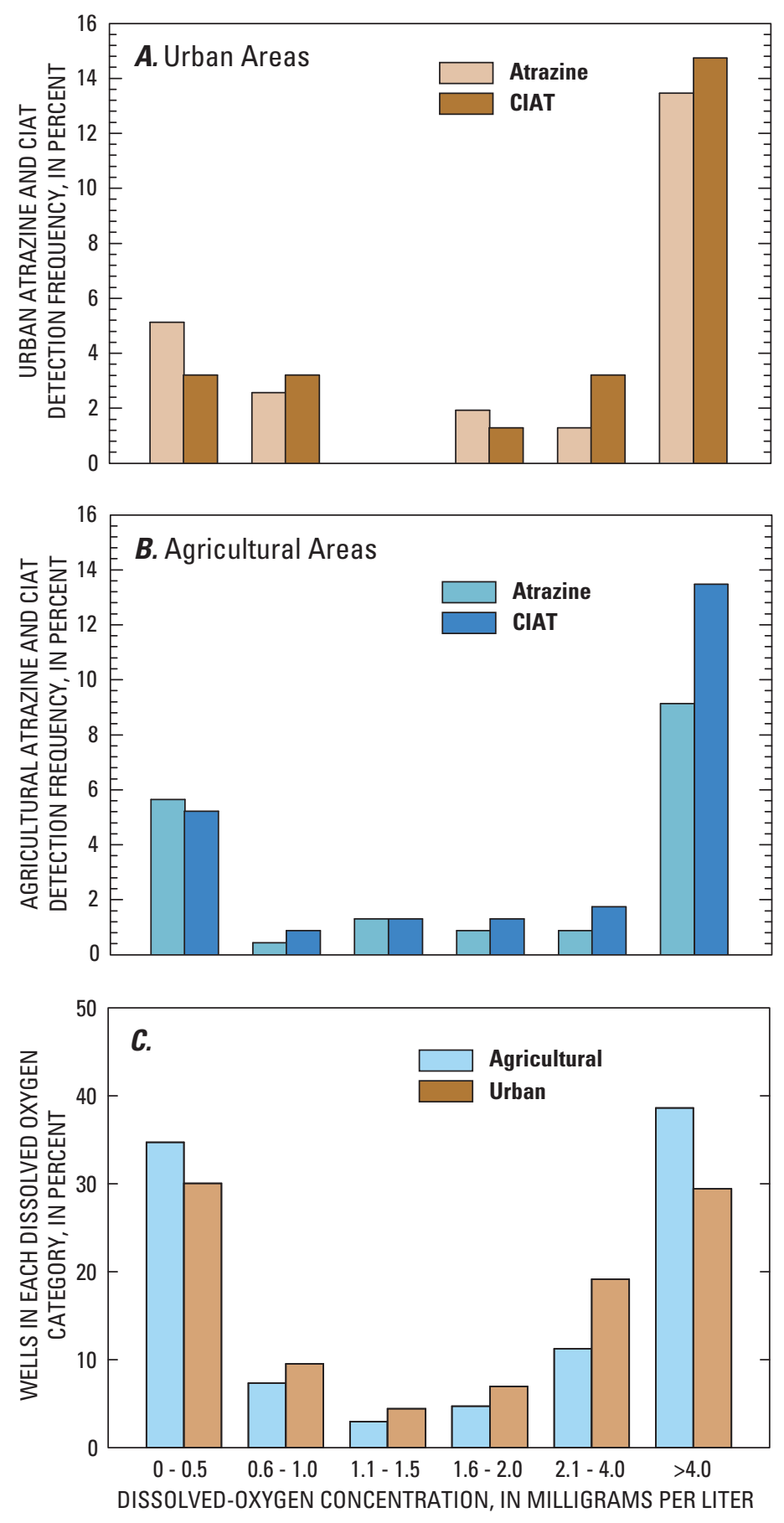

Figure 19. Relation of atrazine and deethylatrazine (CIAT) detection frequencies in ground-water samples collected from $(A)$ urban and $(B)$ agricultural areas to $(C)$ percentage of agricultural and urban wells within each dissolvedoxygen category within regional National Water-Quality Assessment Program study units in the arid to semiarid Western United States, 1993-2004. 


\section{Ureas and Carbamates}

Urea and carbamate pesticides were detected in water from both agricultural and urban wells (fig. 17). The urea pesticide diuron was detected in 13 percent of the samples from agricultural wells but was detected in only 3 percent of the samples from urban wells. The difference in detection frequency between the samples from agricultural and urban wells was significant $(p=0.003)$. Diuron is a general-use herbicide used on forage crops, field crops, fruits, vegetables, nuts, and ornamental crops. Nonagricultural uses of diuron include use on rights-of-way and on irrigation and drainage ditches (Extoxnet, 1993c). Diuron concentrations ranged from less than detection to $0.920 \mu \mathrm{g} / \mathrm{L}$ in agricultural groundwater samples and from less than detection to $0.325 \mu \mathrm{g} / \mathrm{L}$ in urban samples (table 8). Important factors associated with the detection of diuron were percent land use (agricultural and urban), dissolved oxygen, temperature, general soilpermeability characteristics, and population density (table 8). Like simazine, the detection frequency of diuron was more strongly correlated with percent agricultural land use than urban land use $(p<0.05)$. Tebuthiuron is a broadspectrum urea herbicide used to control woody and herbaceous plants in noncropland areas, rangelands, rights-of-way, and industrial areas. Tebuthiuron was detected significantly more frequently ( $p=0.008)$ in water from urban wells (4.5 percent) than agricultural wells $(0.7$ percent). Tebuthiuron was detected in water from wells located within urban areas of GRSL, NVBR, SACR, and SOCA. Tebuthiuron is used in some areas to control alfalfa (Extoxnet, 1993d), an important crop in most agricultural areas within the regional study area (CAZB, NVBR, RIOG, and SANJ). Tebuthiuron was detected in water from only two agricultural wells (one each in SACR and SANJ). Because of the relatively low detection frequency, a sufficiently strong logistic model could not be developed for this herbicide. However, the association of tebuthiuron occurrence and "recreational grasses" showed a positive correlation in urban areas $(p<0.05$; table 8).

Of the carbamate pesticides, carbofuran and thiobencarb were detected in water from 1.5 and 0.7 percent of the agricultural wells, respectively (fig. 20). The agricultural detections of thiobencarb were in samples collected from two wells within the SACR study unit. Less than 1 percent of the samples from urban wells had a detection of either carbofuran ( 0.6 percent) or thiobencarb ( 0.6 percent). The differences between agricultural and urban carbofuran and thiobencarb were not determined to be statistically significant $(p>0.05)$.

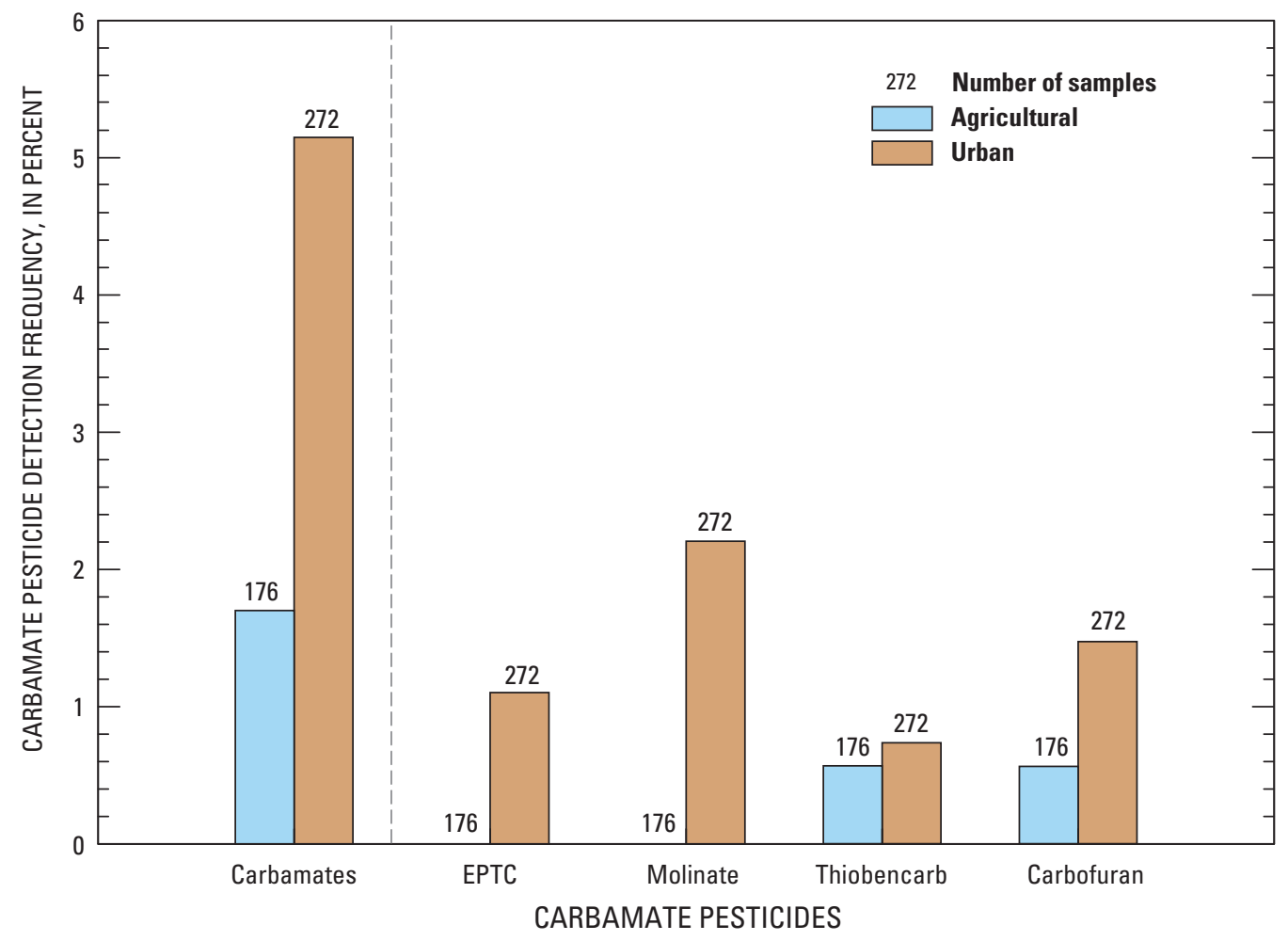

Figure 20. Carbamate detection frequency in ground-water samples collected from agricultural and urban areas within regional National Water-Quality Assessment Program study units in the arid to semiarid Western United States, 1993-2004. 
Carbofuran is a broadspectrum insecticide used to control pests such as insects, mites, and nematodes. Use of granular carbofuran was banned in 1994; however, restricted use of liquid formulations is still permitted for use on field, fruit, vegetable, and forest crops (Extoxnet, 1993e). The herbicide thiobencarb is used primarily for the cultivation of rice (Pesticide Action Network North America, 2006). The most commonly detected carbamate herbicide was molinate, which was detected in water from 2 percent of the agricultural wells (fig. 20). However, molinate was only detected in agricultural area of the SACR study unit and is likely associated with rice cultivation. The thiocarbamate EPTC was detected in water from 1 percent of the agricultural wells (fig. 20) but was only detected in the SANJ study unit. EPTC is a selective herbicide used to control annual grasses, perennial weeds, and some broadleaf weeds in beans, forage legumes, corn, and sweet potatoes (Extoxnet, 1993f).

\section{Other Pesticides}

Bentazon, metolachlor, dinoseb, and norflurazon were detected in water from $6,6,3$, and 2 percent of the agricultural wells, respectively (fig. 17). Bentazon was detected primarily in water from wells within the SACR agricultural area. Bentazon is used primarily on soybeans, rice, and corn (Extoxnet, 1993g). The amide, metolachlor, was detected in water from 6 percent of the agricultural wells, all from the RIOG and SANJ study units, and none from the urban wells. Nationally, metolachlor was ranked number two in agricultural use and primarily is used in the cultivation of corn (Gilliom and others, 2006), but is also used on soybeans, peanuts, potatoes, cotton, and woody ornamentals (Extoxnet, 1993h). Nonagricultural uses of metolachlor include turf, nursery stock, fence lines, and landscaping (Gilliom and others, 2006). By using logistic regression, metolachlor occurrence in shallow ground water underneath agricultural areas was positively correlated to percent row crop and negatively correlated to sprinkler irrigation methods ( $p<0.05$, table 8) Generally, dinoseb has been used as a nonselective contact herbicide in orchards and vineyards, a selective contact herbicide in alfalfa, clover, onions, garlic, and small grains, and as a pre-emergent herbicide (Extoxnet, 1993i). Although dinoseb was banned from use in the United States in 1986, it
Pesticide-use data are available for all study units in the regional area on a county-scale basis, but also are available on a townshipand-range scale in areas in California. With the assumption that the township-and-range-scale data portray a more accurate representation of pesticide use, comparison of pesticide-use data in California on the two scales indicates that county-scale data generally underestimate simazine use in areas where the agricultural wells were located (figs. 21A-C). There is greater variability in the application rates of simazine in the data set at the township-and-range scale (8.1 to $23,196 \mathrm{lbs} / \mathrm{acre})$ than at the county scale (5.4 to $59.4 \mathrm{lbs} / \mathrm{acre})$ (fig. $21 C, p<0.05$ ). Although, simazine is used in this report as an example, other pesticides for which data were available at both scales showed similar results. On a national scale, the diversity of agricultural crop types, climate, and pesticide use made it impossible to elucidate differences among the different agricultural settings (Gilliom and others, 2006). was detected in water from eight wells in the SANJ study unit. Dinoseb does not strongly adsorb to soil and is susceptible to microbial degradation but has been determined to be persistent in some areas (Extoxnet, 1993i). The source of dinoseb to the ground water in this area is unclear. Norflurazon was detected in ground water from the SOCA and SANJ study units. Norflurazon is a pre-emergent herbicide used to control germinating annual grasses and broadleaf weeds in crops such as cotton, soybeans, citrus, nectarines, and almonds. Nonagricultural uses of norflurazon are permitted on airports and rights-of-way (Pesticide Management Education Program, 1984a).

Important factors in pesticide occurrence at a national scale include pesticide use, climate, recharge source, soil characteristics, irrigation practices, pesticide residence time within an aquifer, environmental redox conditions, pesticide physical and chemical properties, and attenuation processes (Barbash, 2003; Gilliom and others, 2006). Overall pesticide use was determined to be greatest in corn and soybean crops and lowest in wheat and alfalfa crops (Gilliom and others, 2006). Most of the crops in areas included in this study were wheat and alfalfa, with four of the five agricultural areas in this study (CAZB, NVBR, RIOG, SACR, and SANJ) reporting alfalfa as a primary crop type. Therefore, the relatively low detection frequencies of pesticides in samples collected from the arid to semiarid Western United States are not unexpected. 


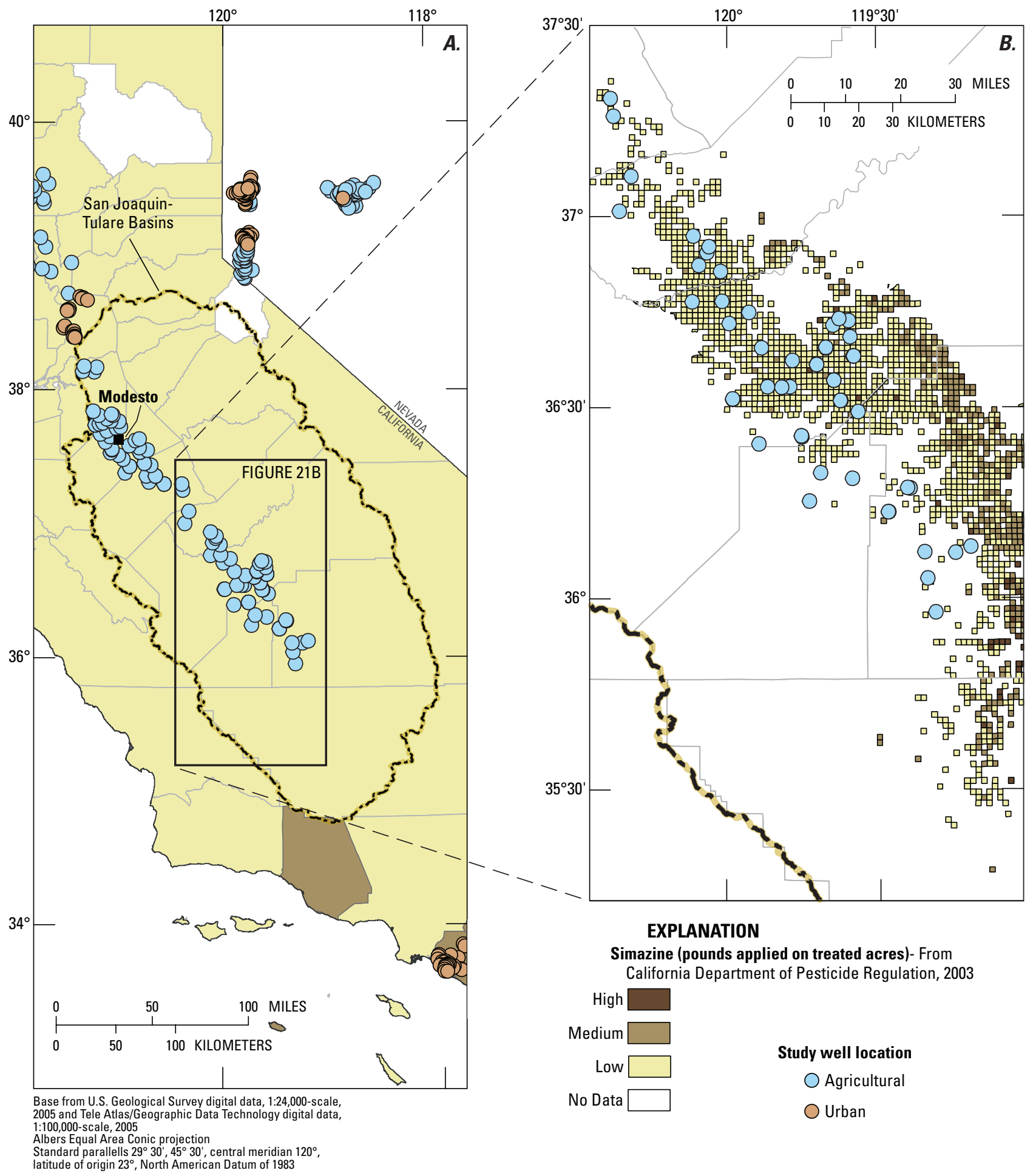

Figure 21. Simazine pesticide use by $(A)$ county and $(B)$ township-and-range-scale coverages, and $(C)$ graphical comparison of pesticide-use scales in the San Joaquin-Tulare Basins (SANJ) study unit. 


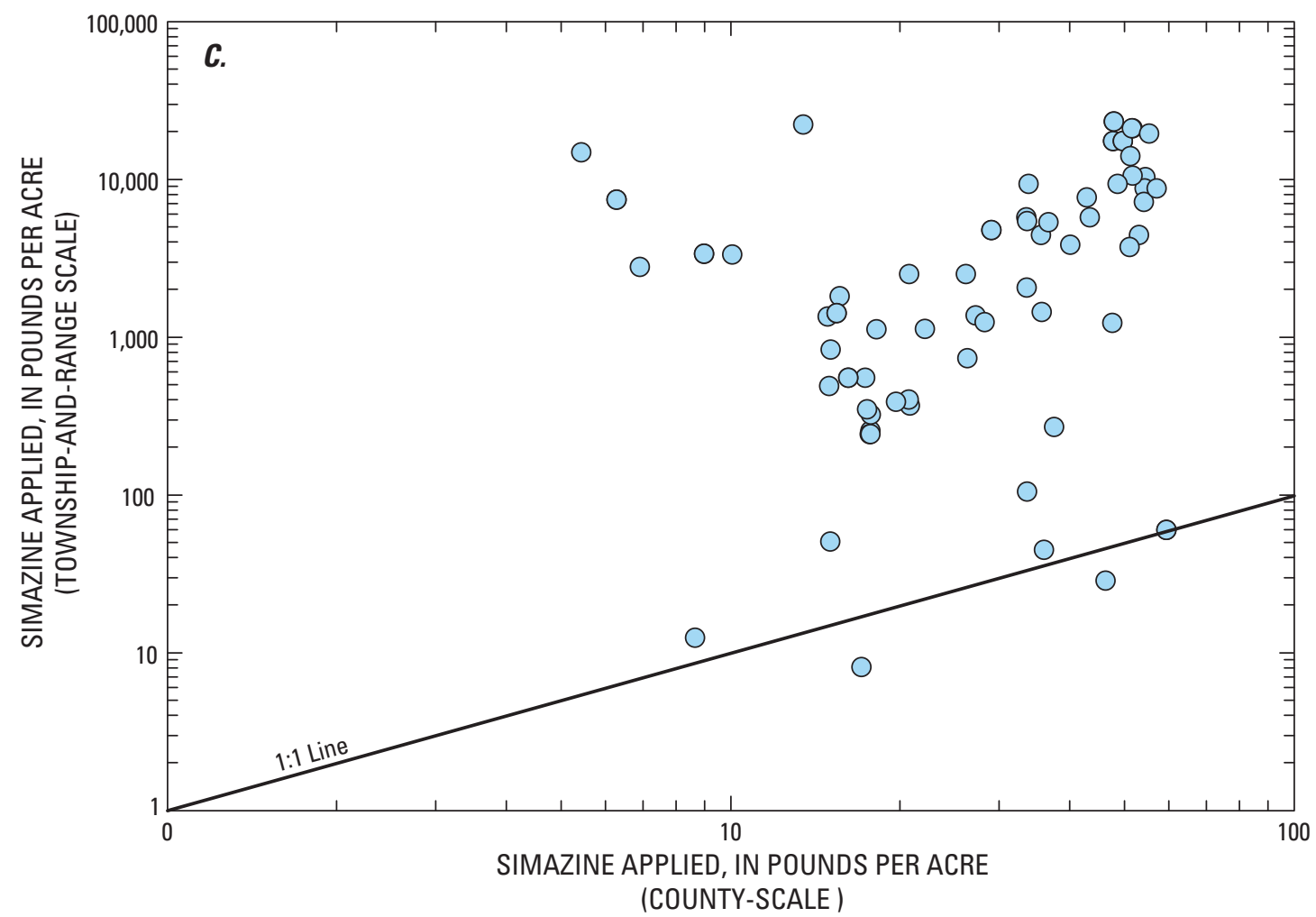

Figure 21.-Continued.

\section{Volatile-Organic Compounds}

Trihalomethanes (THMs), solvents (tetrachloroethene, trichloroethene), and the fuel oxygenate methyl tert-butyl ether (MTBE) were detected more frequently in ground water from urban areas than agricultural areas $(p<0.05)$. BTEX (benzene, toluene, ethylbenzene, xylene), chlorofluorocarbons (CFCs), and fumigants (dibromochloropropane; 1,2-dichloropropane; 1,2,3-trichloropropane) were detected more commonly in agricultural areas (fig. 22). The differences between BTEX and $\mathrm{CFC}$ detection frequencies within agricultural and urban areas were not determined to be significant $(p>0.05)$.

\section{Trihalomethanes}

THMs are commonly produced during the disinfection of drinking water with chlorine (Zogorski and others, 2006) when the chlorine reacts with naturally occurring organic matter present in the water (Bellar and others, 1974). The current USEPA criterion for total THM concentration is $80 \mu \mathrm{g} / \mathrm{L}$ (U.S. Environmental Protection Agency, 2006a); that value was not exceeded in any samples included in this investigation. The concentration of the most commonly detected THM, trichloromethane (chloroform), in urban areas ranged from less than 0.2 to $40.4 \mu \mathrm{g} / \mathrm{L}$ and from less than 0.2 to $0.34 \mu \mathrm{g} / \mathrm{L}$ in agricultural areas (table 9). The difference between urban and agricultural chloroform detection frequency was significant $(p<0.05)$. Where THMs were detected, chloroform predominated (fig. 23), which is similar to the findings of the national assessment of VOC occurrence and distribution (Zogorski and others, 2006). Brominated THM concentrations ranged from less than 0.2 to $3.39 \mu \mathrm{g} / \mathrm{L}$ in urban ground-water samples and were not detected in agricultural areas. Mono- and di-chlorinated THM compounds were detected only in ground water in urban areas. As bromifications within the THM molecule increased, detection frequency decreased (fig. 23), which also was observed during the national VOC assessment (Zogorski and others, 2006). Although the detections of dichlorobromomethane $\left(\mathrm{CHBrCl}_{2}\right)$ and dibromochloromethane $\left(\mathrm{CHClBr}_{2}\right)$ could result from spills during their historical use as industrial solvents, reagents, and (or) flame retardants (Agency for Toxic Substances and Disease Registry, 1989; GreenFacts, 2006), Zogorski and others (2006) attributed their detection to the use of chlorine in the disinfection of water process. The THM compounds detected within the study area likely are disinfection byproducts resulting from the treatment of water with chlorine and subsequent use of the treated water on landscaping (Squillace and others, 1999; Edmonds and Gellenbeck, 2002; Thiros, 2003a; Ivahnenko and Barbash, 2004). 


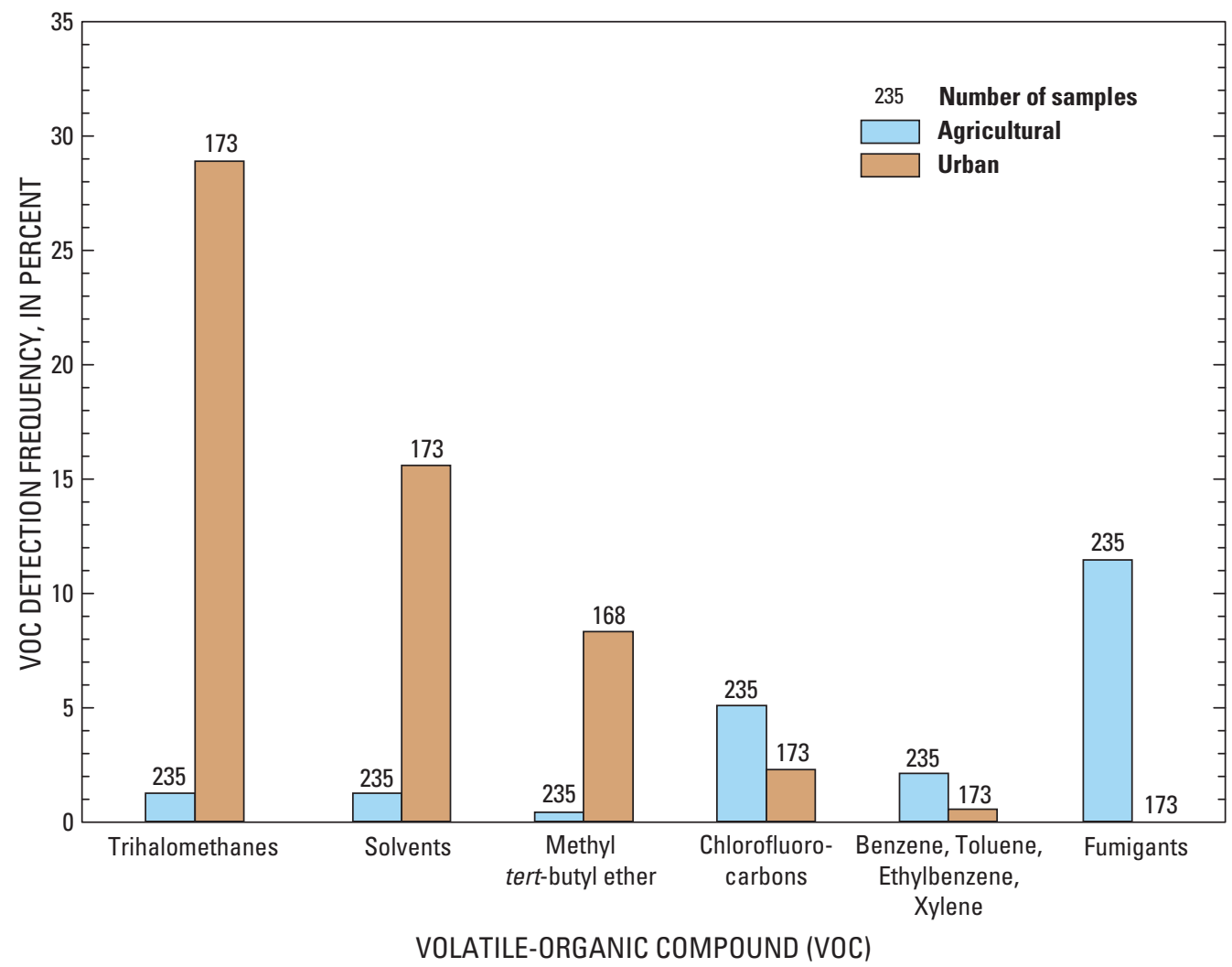

Figure 22. Volatile-organic compound class detection frequency in ground-water samples collected from agricultural and urban areas within regional National Water-Quality Assessment Program study units in the arid to semiarid Western United States, 1993-2004.

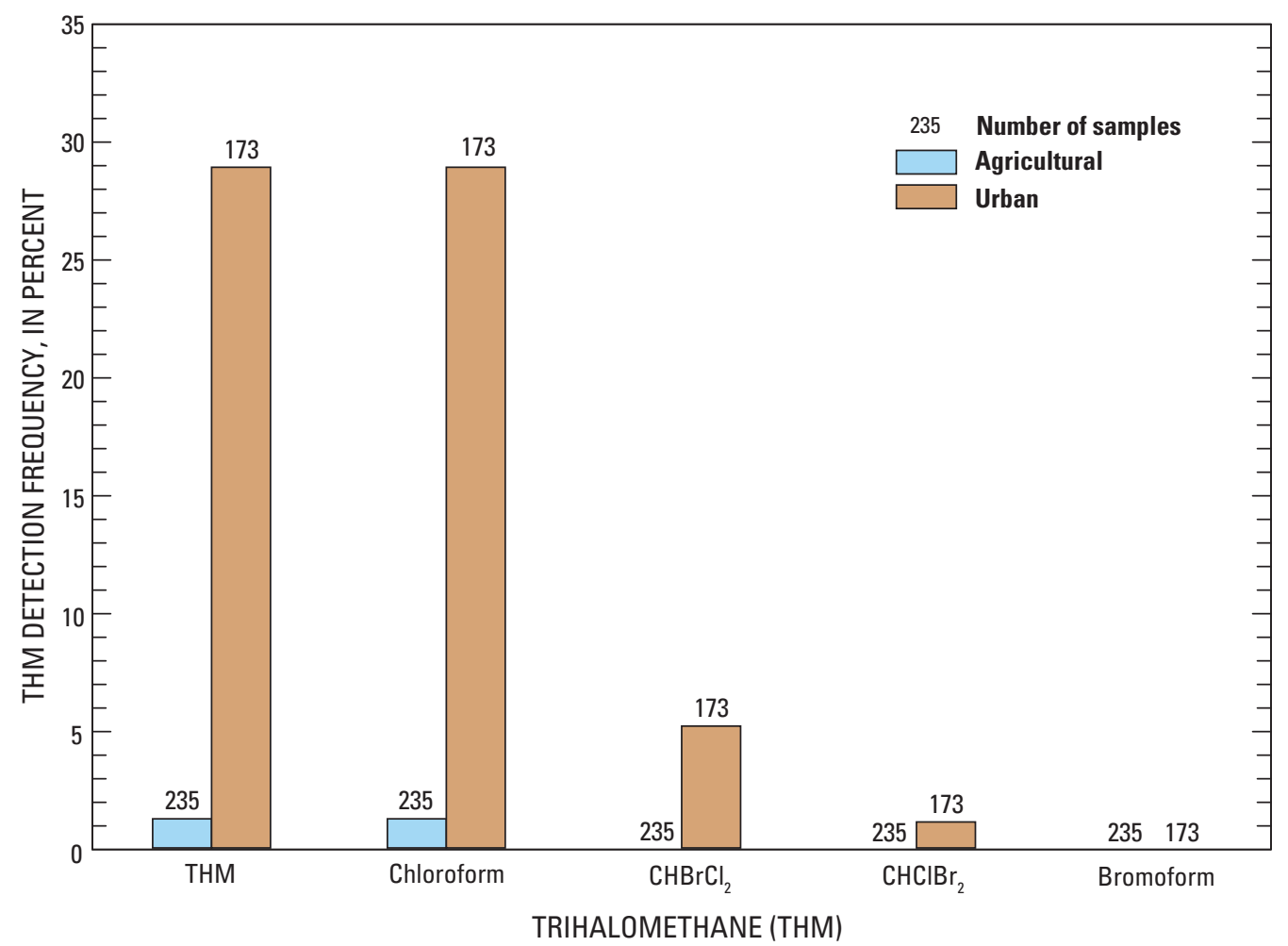

Figure 23. Trihalomethane detection frequency in samples collected from agricultural and urban areas within regional National Water-Quality Assessment Program study units in the arid to semiarid Western United States, 1993-2004. 
Table 9. Volatile-organic compound occurrence in shallow ground water beneath agricultural and urban areas within regional National Water-Quality Assessment Program study units in the arid to semiarid Western United States, 1993-2004.

[The "+" and "-" signs indicate a positive and negative correlation, respectively, of volatile-organic compound occurrence to designated explanatory variable. Abbreviations: DBCP, 1,2-dibromo-3-chloropropane; MCL, maximum contaminant level; USEPA, U.S. Environmental Protection Agency; VOC, volatile organic compound; RIOG, Rio Grande Valley; SANJ, San Joaquin-Tulare Basins; $\mu \mathrm{g} / \mathrm{L}$, microgram per liter; nd, not determined. Symbol: <, less than]

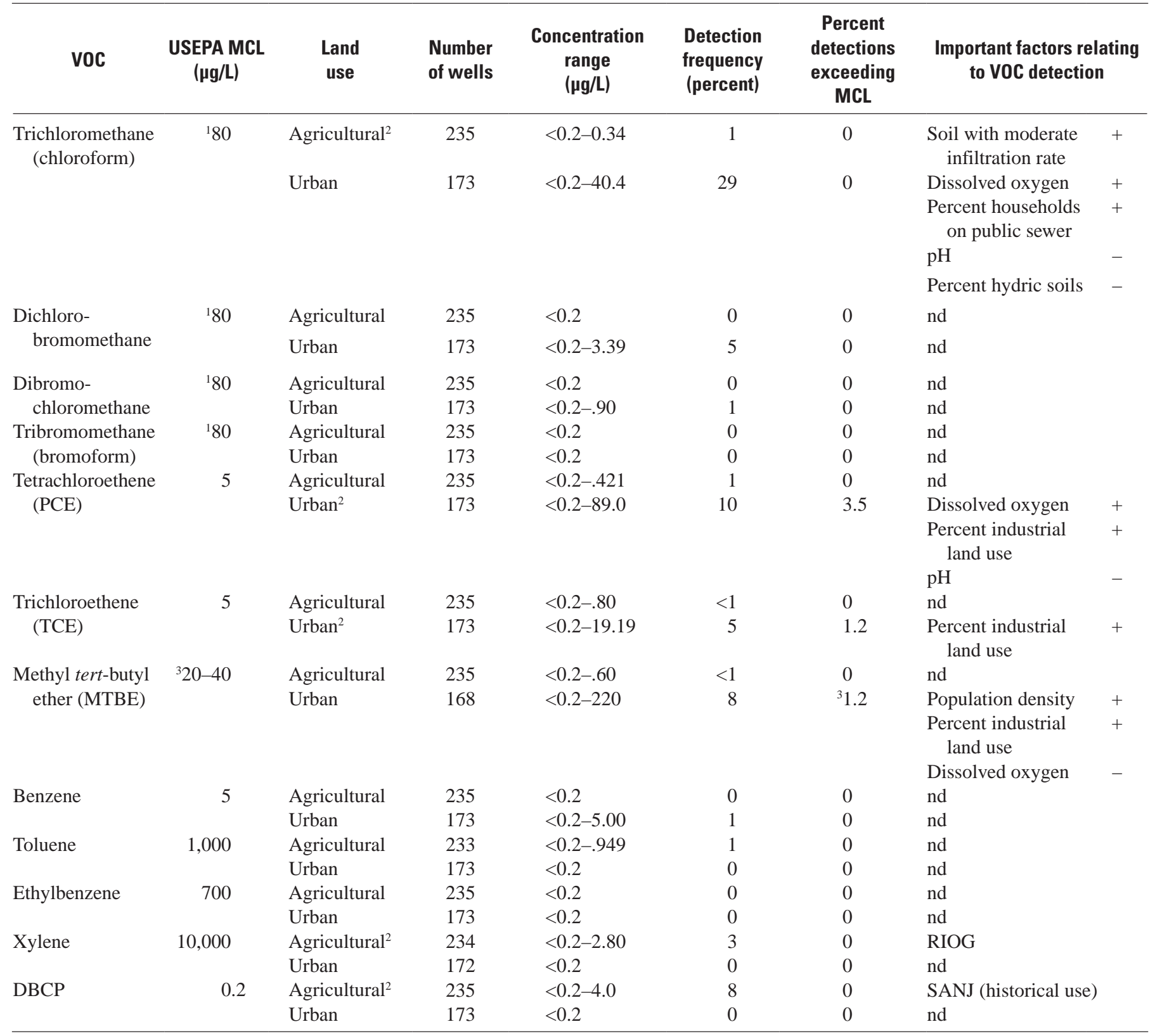

\footnotetext{
${ }^{1}$ Total THM MCL.
}

${ }^{2} \mathrm{~A}$ sufficiently strong logistic-regression model was not developed for this volatile-organic compound within areas of this land use. However, the parameters listed were determined to be important in the occurrence of the volatile-organic compound $(p<0.05)$.

${ }^{3}$ USEPA drinking-water advisory. 
With a logistic model, the detection frequency of chloroform in urban areas was associated with $\mathrm{DO}, \mathrm{pH}$, percentage of households on public sewer, and percentage of hydric soil within the 500-meter buffer areas $(p<0.05$; table 9). Nationally, chloroform was determined to be associated with percent urban land use, aerobic conditions within the aquifer, areas with relatively high precipitation rates (high aquifer recharge areas), public supplywells, low amounts of anaerobic soils, percentage of households on septic systems, and proximity to Resource Conservation and Recovery Act (RCRA) facilities (Zogorski and others, 2006).

The minimum DO concentration in water from wells with detectable amounts of chloroform was $0.5 \mathrm{mg} / \mathrm{L}$ (fig. 24). Under aerobic conditions, chloroform is more stable than its degradation products (Zogorski and others, 2006). In both agricultural and urban areas, chloroform was more commonly detected in ground water with DO concentrations above $1.5 \mathrm{mg} / \mathrm{L}$ than in ground water with DO concentrations below $1.0 \mathrm{mg} / \mathrm{L}$ (fig. 24).

\section{Solvents}

Similar to the national results (Zogorski and others, 2006), solvents were the second most frequently detected class of VOCs (fig. 22). Tetrachloroethene (PCE) and trichloroethene (TCE) were the most commonly detected solvents in ground-water samples (fig. 25). Concentrations of PCE ranged from less than 0.2 to $89.0 \mu \mathrm{g} / \mathrm{L}$ and TCE concentrations ranged from less than 0.2 to $19.19 \mu \mathrm{g} / \mathrm{L}$ (table 9 ). Water from five wells in urban areas within NVBR and one well in GRSL had PCE concentrations exceeding the USEPA drinking-water criterion $(5 \mu \mathrm{g} / \mathrm{L})$. Water from 2 of the 5 wells in the urbanized land-use areas within the NVBR that exceeded the PCE criterion also exceeded the $5 \mu \mathrm{g} / \mathrm{L}$ TCE criterion. PCE is much less soluble in water $(150 \mathrm{mg} / \mathrm{L})$ than TCE $(1,100 \mathrm{mg} / \mathrm{L})($ German Federal Ministry for Economic Cooperation and Development, 2007; Toxic Use Reduction Institute, 2007); however, both compounds can readily migrate through the unsaturated zone and move with ground water (Russell and others, 1992, p. 1-6).

PCE and TCE were detected in ground water in urban areas (GRSL, NVBR, and SOCA) and in agricultural areas (CAZB and SANJ). There are approximately 19 Superfund (CERCLA) site listings within the regional study area; however, it is unclear to what extent these CERCLA sites are influencing the ground-water quality at sampling locations included in this investigation. In the CAZB study unit, PCE and
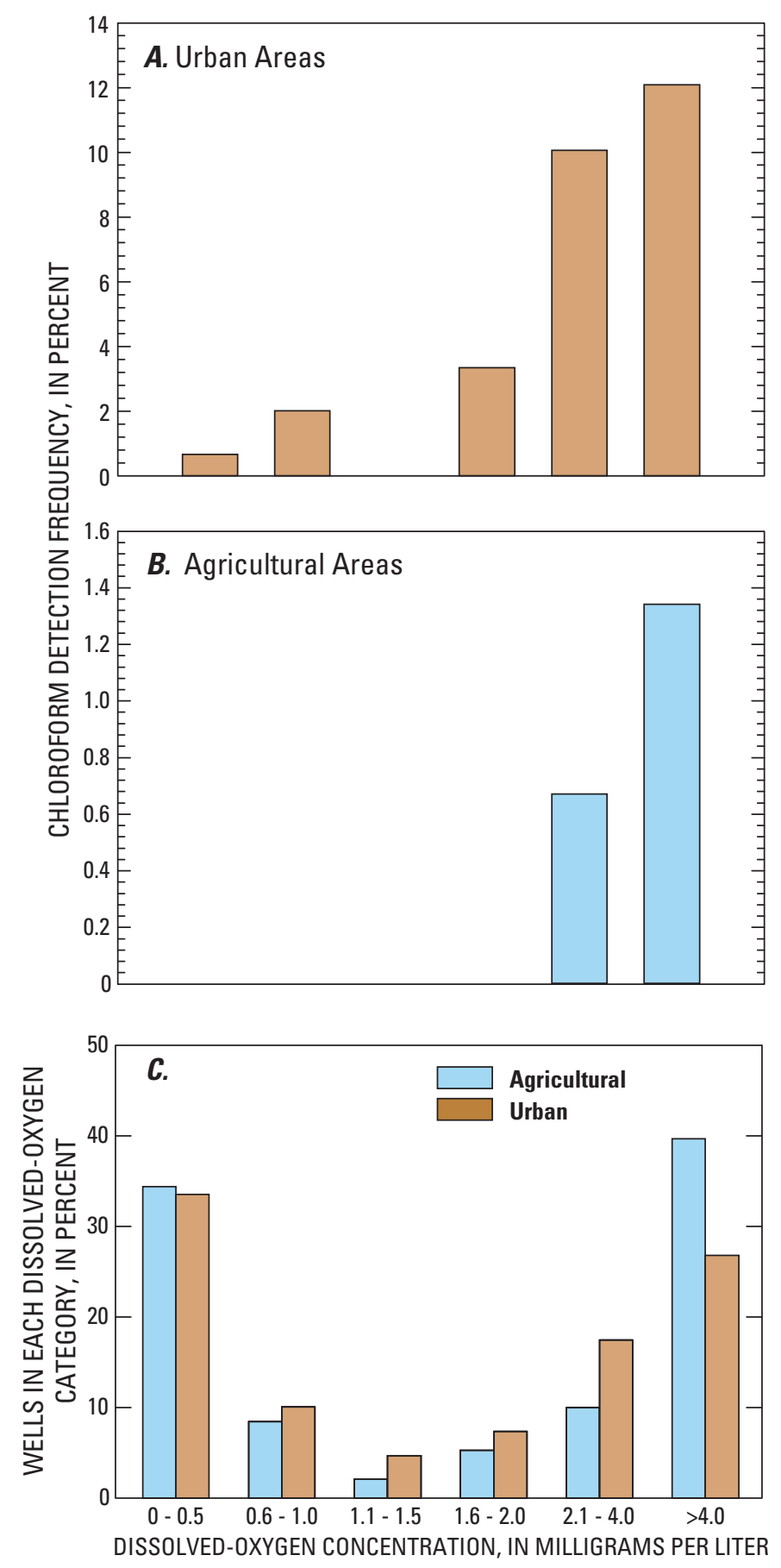

Figure 24. Relation of chloroform detection frequency in ground-water samples collected from $(A)$ urban and $(B)$ agricultural areas to $(C)$ percentage of agricultural and urban wells in each dissolved-oxygen category within regional National Water-Quality Assessment Program study units in the arid to semiarid Western United States, 1993-2004. 


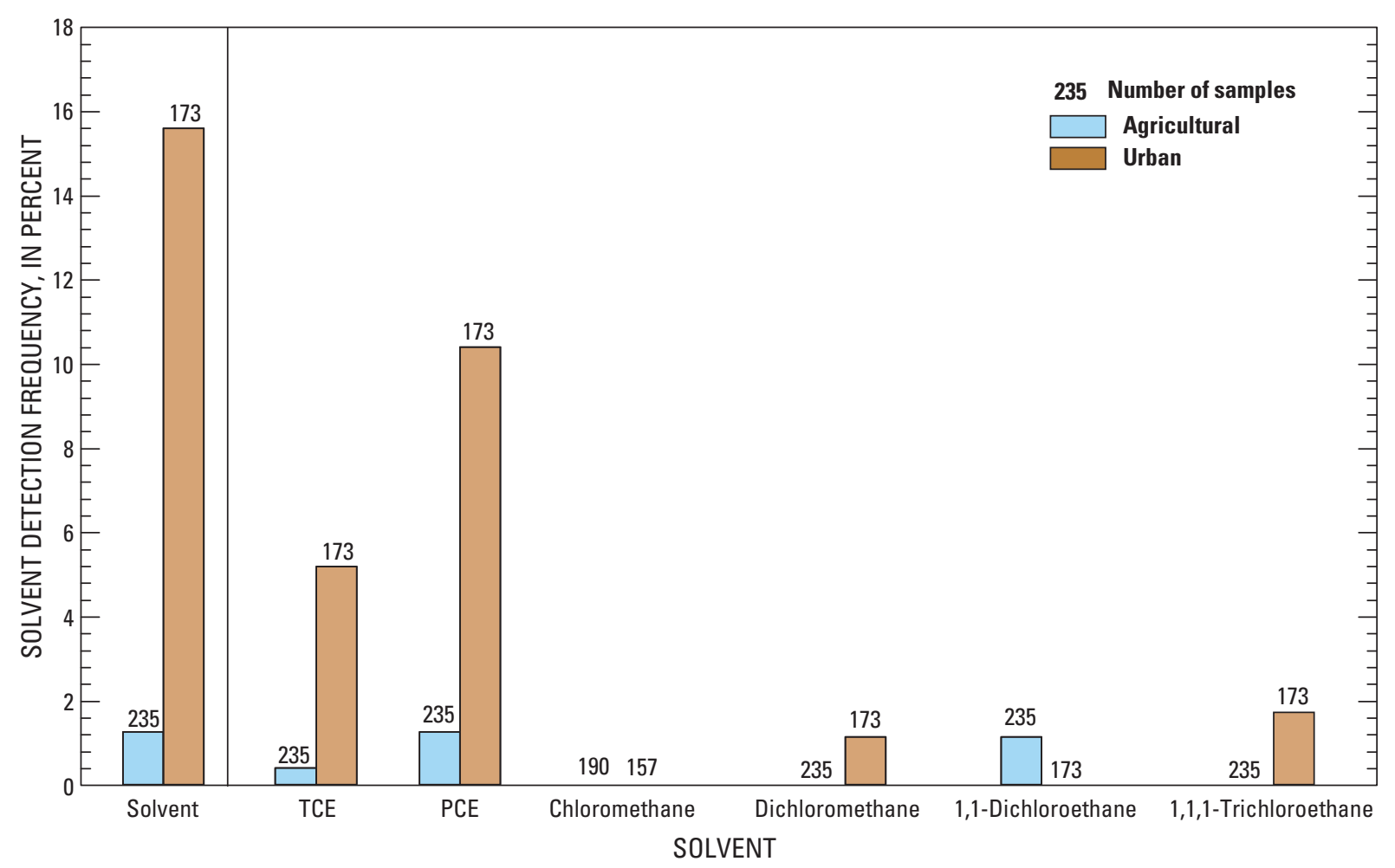

Figure 25. Solvent detection frequency in water from wells sampled from agricultural and urban areas within regional National Water-Quality Assessment Program study units in the arid to semiarid Western United States, 1993-2004.

TCE detections were suspected to be from a solvent plume upgradient from the wells (Gellenbeck and Anning, 2002). The source(s) of PCE detected in samples collected from the GRSL study unit have not been determined (Thiros, 2003a) and is (are) currently under investigation. Within the urbanized areas considered in this report, PCE detection frequency was determined to be associated with DO, percentage of industrial land use, and $\mathrm{pH}(p<0.05$; table 9$)$. Although a sufficiently strong logistic assessment could not be determined for the detection of TCE in our investigation, percentage of industrial land use was a significant explanatory variable $(p=0.001$; table 9).
Although both PCE and TCE are used as industrial solvents, through reductive dehalogenation PCE can be transformed into TCE and eventually vinyl chloride in anaerobic settings (Russell and others, 1992; Vogel and McCarty, 1985). By using univariate correlation statistical analysis, PCE and TCE concentrations were positively correlated to each other $(\rho=0.391$ at $\alpha=0.05)$, and multivariate logistic regression indicated that PCE and TCE detections were associated with each other $(p<0.05)$. Dissolved-oxygen concentration in water from wells where both PCE and TCE were detected ranged from 0.2 to $8 \mathrm{mg} / \mathrm{L}$ (fig. 26). It is unclear whether the detections of TCE result from spills of TCE itself, or from the degradation of spilled PCE. 


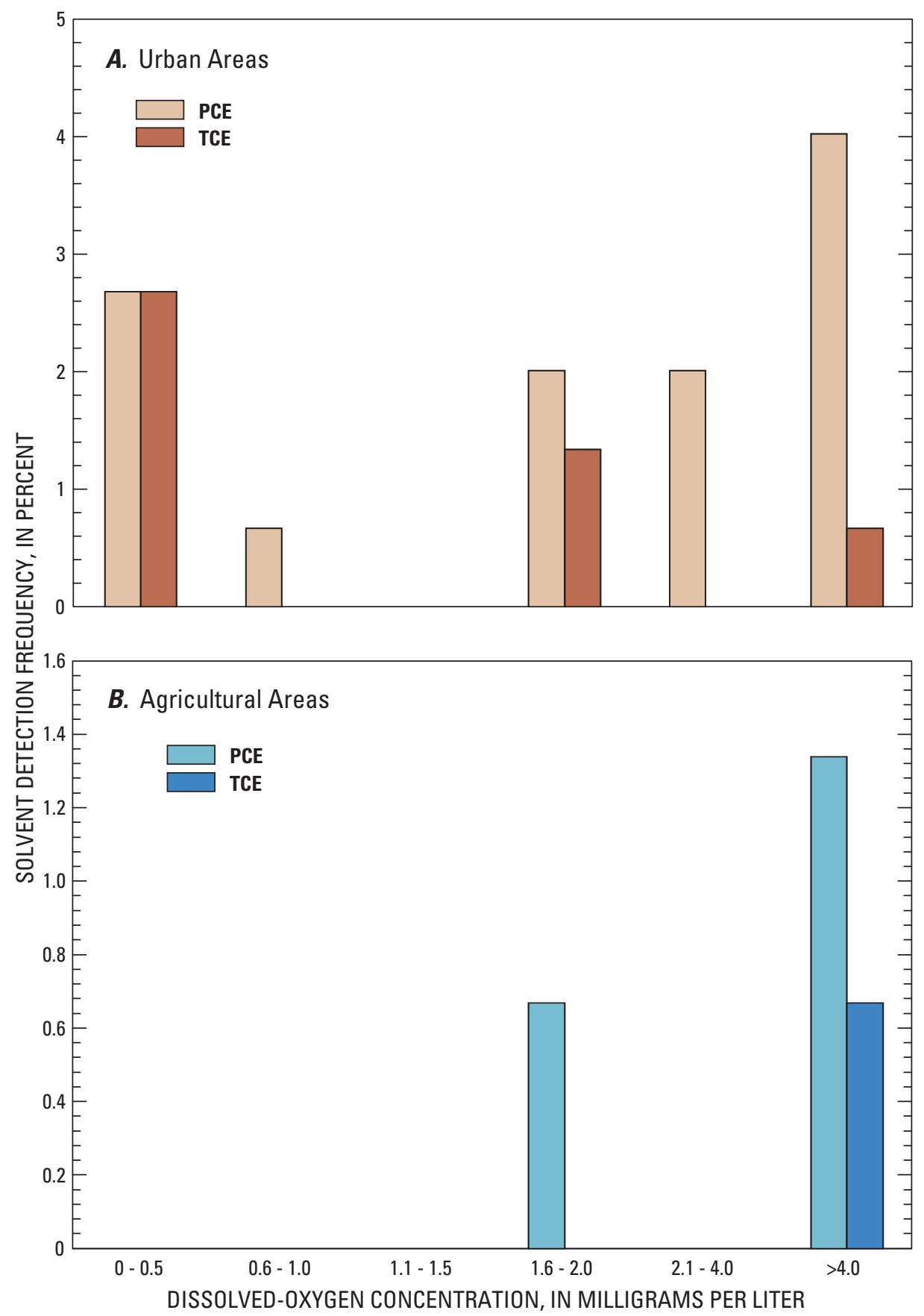

Figure 26. Relation of solvent detection frequencies in ground-water samples collected from $(A)$ urban and $(B)$ agricultural areas to dissolved-oxygen concentration within regional National Water-Quality Assessment Program study units in the arid to semiarid Western United States, 1993-2004. See figure 24C for percentage of agricultural and urban wells within each dissolved-oxygen category. 


\section{Fuel-Related Compounds}

Because of air pollution caused by automobile exhaust, 1990 Clean Air Act Amendments required that oxygenates be added to gasoline (Squillace and others, 1996; Cozzarelli and Baehr, 2003). Fuel oxygenates that have been used include methyl tertbutyl ether (MTBE), ethanol, ethyl tert-butyl ether (ETBE), tert-amyl methyl ether (TAME), and di-isopropyl ether (DIPE) (Cozzarelli and Baehr, 2003). The most commonly detected oxygenate in the environment is MTBE (Cozzarelli and Baehr, 2003). In this study, MTBE was more commonly detected in urban ground water ( 8 percent) than agricultural ground water (less than 1 percent; $p<0.05$ ). Most MTBE detections occurred in water from wells with low dissolved-oxygen concentrations (fig. 27). When using the urban dataset and multivariate analysis, MTBE was positively correlated with population density and percent industrial land use and negatively correlated to DO concentration ( $p<0.05$; table 9). MTBE concentrations exceeded the USEPA drinking-water advisory of $20-40 \mu \mathrm{g} / \mathrm{L}$ in samples collected from two wells in the NVBR study unit $(140 \mu \mathrm{g} / \mathrm{L}$ and $220 \mu \mathrm{g} / \mathrm{L})$ and ranged from 0.2 to $12.7 \mu \mathrm{g} / \mathrm{L}$ in samples from all other wells.

BTEX (benzene, toluene, ethylbenzene and xylene) compounds are aromatic-organic chemicals associated with crude oil (Cozzarelli and Baehr, 2003) and frequently are associated with fossil fuels and car exhaust. Benzene was detected in two samples from urban ground water in the NVBR study unit.

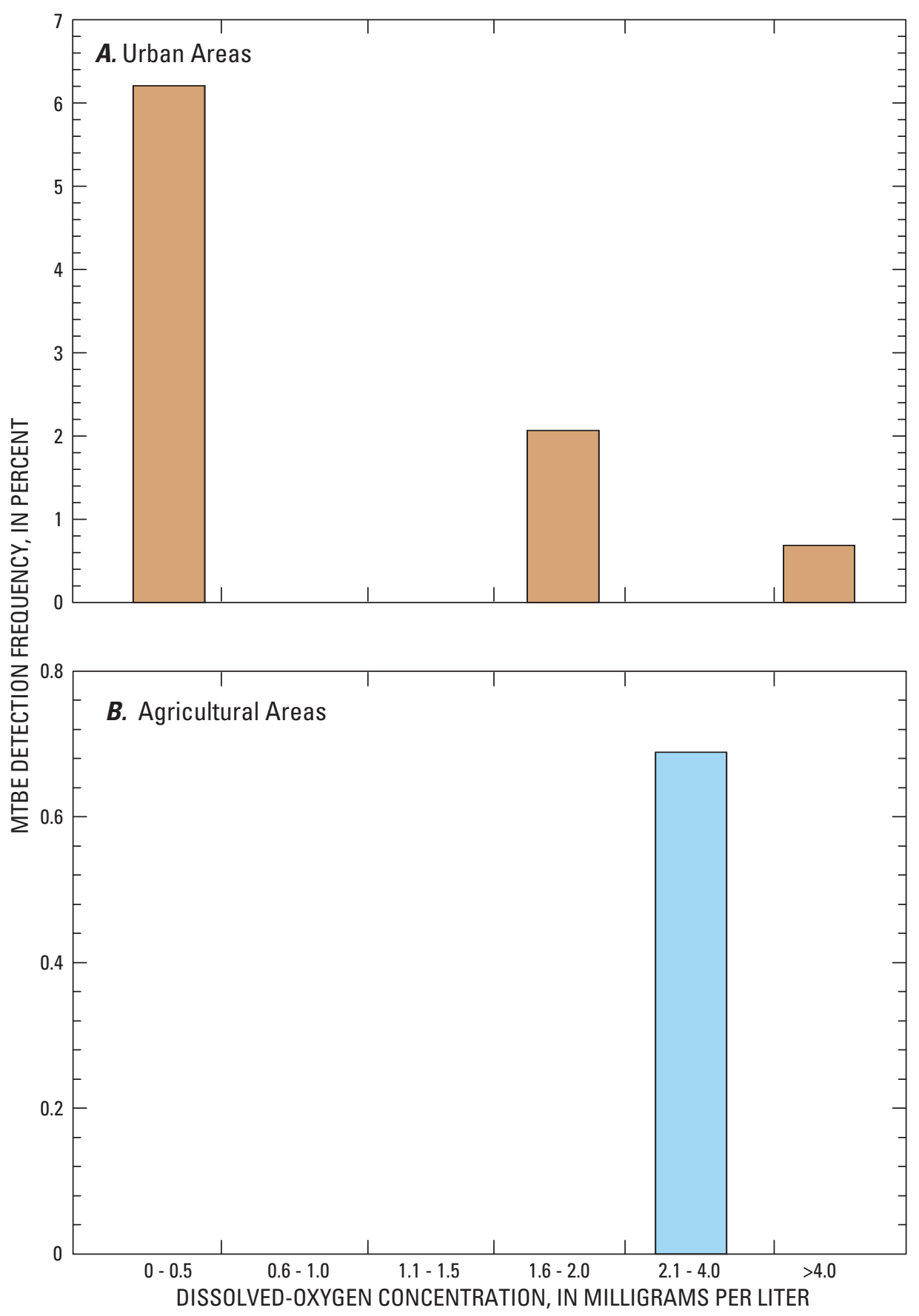

Figure 27. Relation of methyl tert-butyl ether (MTBE) detection frequency collected from $(A)$ urban and $(B)$ agricultural areas to dissolved-oxygen concentration within regional National Water-Quality Assessment Program study units in the arid to semiarid Western United States, 1993-2004. See figure 24C for percentage of agricultural and urban wells within each dissolved-oxygen category. 
Toluene was detected in water from 3 of the 238 agricultural wells (all within the SANJ study unit) and in 2 urban ground-water samples from NVBR. Ethylbenzene was not detected at concentrations greater than $0.2 \mu \mathrm{g} / \mathrm{L}$ in any well sampled as part of this assessment. Xylene was the most commonly detected of the BTEX compounds -50 percent of the BTEX detections-but was only detected in ground water collected from the RIOG agricultural area. The low detection frequencies and distribution pattern of these BTEX compounds make it difficult to assess factors resulting in their detection patterns.

\section{Chlorofluorocarbons and Fumigants}

The CFCs, trichlorofluoromethane (CFC-11) and 1,1,2trichloro-1,2,2-trifluoroethane (CFC-113, also known as Freon), were detected in ground water as part of this study. Although CFC-113 was detected slightly more frequently in water from urban wells (1 percent) than agricultural wells (0.4 percent), this difference was not statistically significant $(p=0.445)$. CFC-11 was detected significantly more often in agricultural than urban areas $(p=0.021)$. CFC-11 has been used as a refrigerant and as an aerosol propellant during the application of insecticides (Spectrum Laboratories, Inc., 2006) and was detected in water from 12 wells in the SANJ agricultural area and 3 times in the NVBR urban area.

The most commonly detected fumigant was dibromochloropropane (DBCP) which, with the exception of one well in the CAZB study unit, was detected only in ground water from the SANJ study unit. Nationally, this fumigant also has been detected in Hawaii (Zogorski and others, 2006) and was used as a soil fumigant for the control of nematodes in vegetable and ornamental crops (U.S. Environmental Protection Agency, 2006b) until it was banned in the late 1970s, except for use on pineapples (Pesticide Management Education Program, 1984b). The other fumigants, 1,2dichloropropane and 1,2,3-trichloropropane, were detected in water from 2 and 3 percent of the agricultural wells, respectively, with all detections being in the SANJ study unit. 1,2-dichlorpropane has been used as a soil fumigant, industrial solvent, and chemical intermediate for the synthesis of PCE (Agency for Toxic Substances and Disease Registry, 1999). The fumigant, 1,2,3-trichloropropane, was used as an industrial solvent and cleaning/degreasing agent (Agency for Toxic Substances and Disease Registry, 1995). One sample collected from the SANJ study unit showed co-occurrence of PCE, TCE, 1,2-dichloropropane, and 1,2,3-trichloropropane.

\section{Summary and Conclusions}

The primary nutrients detected in shallow ground water in agricultural and urban areas in the arid to semiarid Western United States were nitrate and orthophosphorus. Generally, nitrate concentrations were greater in agricultural areas than in urban areas. Currently (2007), there is no drinking-water criterion for phosphate; however, the U.S. Environmental Protection Agency (USEPA) maximum contaminant level (MCL) for nitrate is $10 \mathrm{mg} / \mathrm{L}$. This MCL was exceeded in every study unit included in this investigation. In agricultural and urban areas, the nitrate MCL was exceeded in water from 25 and 10 percent of the wells, respectively. Nationally, 15 percent of shallow ground water sampled in agricultural and urban areas exceeded the USEPA nitrate criterion. The probability of exceeding the nitrate standard in agricultural areas can be estimated by the interaction of three primary parameters: irrigation practices, fertilizer use, and aquifer redox condition. Fertilizer application rate and sprinkler irrigation practices were positively correlated to the exceedance of the nitrate standard. High iron concentration, typically associated with low dissolved-oxygen concentration and considered indicative of reducing environments, showed a negative relation to the exceedance of the nitrate MCL. The lowest median nitrate concentrations occurred in areas with the lowest median dissolved-oxygen concentrations.

The triazines were the predominant class of pesticide detected in both agricultural and urban areas. Simazine was detected more frequently in ground water beneath agricultural areas, whereas atrazine and prometon were more commonly associated with urbanized areas. The second most commonly detected class of pesticide was the ureas. Of the urea herbicides, diuron was associated with agriculture and tebuthiuron with urbanization. Because of the relatively low detection frequencies of pesticides in shallow ground water in both agricultural and urban areas included in this investigation, sufficiently strong predictive models for the detection of pesticides in these systems could not be determined. However, in general, aquifer redox condition, temperature, general soilpermeability characteristics, and depth to screened interval were determined to be important factors to consider when examining environmental controls on pesticide occurrence. All pesticide concentrations were below established USEPA drinking-water criteria.

Volatile-organic compounds (VOCs) were more commonly associated with ground water underlying urban areas than agricultural areas. The most commonly detected VOCs in this investigation belonged to the disinfection by- 
product, trihalomethane (THM), category. Of the THMs, the most prevalent was chloroform. The solvents, PCE and TCE, also were commonly detected in shallow groundwater samples collected in urbanized areas. Of the gasolinerelated VOCs, BTEX (benzene, toluene, ethylbenzene, xylene) and MTBE, MTBE was detected most frequently. Chloroform, PCE, and MTBE detection frequencies were influenced by aquifer redox condition. Chloroform and PCE detection frequencies increased with increasing dissolvedoxygen concentrations, whereas MTBE was detected more frequently when dissolved-oxygen concentration was low. Other important explanatory factors influencing the detection of VOCs in shallow ground water included $\mathrm{pH}$ and percent industrial land use. The MCL for total THMs $(80 \mu \mathrm{g} / \mathrm{L})$ was not exceeded in any sample included in this data analysis. However, the MCL for PCE $(5 \mu \mathrm{g} / \mathrm{L})$, TCE $(5 \mu \mathrm{g} / \mathrm{L})$, and the drinking-water advisory for MTBE $(20-40 \mu \mathrm{g} / \mathrm{L})$ was exceeded in $3.5,1.2$, and 1.2 percent of the urban samples included in this investigation, respectively.

\section{Acknowledgments}

The authors gratefully acknowledge the contributions from the following USGS personnel: David W. Anning, Susan A. Thiros, Scott N. Hamlin, Jennifer L. Shelton, and Karen R. Burow for their contributions in describing the hydrogeologic setting of agricultural and urban areas from which data were collected and interpreted within this report; and Michael Rupert for his guidance in using logisticregression methods for assessing relations among ancillary data and the occurrence of contaminants.

\section{References Cited}

Agency for Toxic Substances and Disease Registry, 1989, Toxicological profile for bromodichloromethane: Agency for Toxic Substances and Disease Registry, accessed June 12, 2007, at http://www.atsdr.cdc.gov/toxprofiles/tp129c4.pdf.

Agency for Toxic Substances and Disease Registry, 1995, $\mathrm{ToxFAQ}^{\mathrm{TM}}$ for 1,2,3-Trichloropropane: Agency for Toxic Substances and Disease Registry, accessed August 8, 2006, at http://www.atsdr.cdc.gov/tfacts57.html.

Agency for Toxic Substances and Disease Registry, 1999, ToxFAQ ${ }^{\mathrm{TM}}$ for 1,2-Dichloropropane: Agency for Toxic Substances and Disease Registry, accessed August 8, 2006, at http://www.atsdr.cdc.gov/tfacts134.html.
Anderholm, S.E., 1996, Water-quality assessment of the Rio Grande Valley, Colorado, New Mexico, and TexasShallow ground-water quality of a land use area in the San Luis Valley, south-central Colorado, 1993: U.S. Geological Survey Water-Resources Investigations Report 96-4144, $94 \mathrm{p}$.

Anderholm, S.E., 1997, Water-quality assessment of the Rio Grande Valley, Colorado, New Mexico, and Texas-Shallow ground-water quality and land use in the Albuquerque area, central New Mexico, 1993: U.S. Geological Survey Water-Resources Investigations Report 97-4067, $73 \mathrm{p}$.

Anderholm, S.E., 2002, Water-quality assessment of the Rio Grande Valley, Colorado, New Mexico, and TexasSurface-water quality, shallow ground-water quality, and factors affecting water quality in the Rincon Valley, southcentral New Mexico, 1994-95: U.S. Geological Survey Water-Resources Investigations Report, 117 p.

Anderson, T.W., Freethey, G.W., and Tucci, Patrick, 1992, Geohydrology and water resources of alluvial basins in south-central Arizona and parts of adjacent states: U.S. Geological Survey Professional Paper 1406-B, 67 p.

Barbash, J.E., 2003, The geochemistry of pesticides, in Holland, H.D., and Turekian, K.K., eds., Treatise on geochemistry: [Burlington, Mass.?], Elsevier, v. 9, p. 541-577.

Barbash, J.E., and Resek, E.A., 2000, Chapter 6: Influence of pesticide properties, environmental setting, and study design on pesticide detections, in Pesticides in ground water: Distribution, trends, and governing factors: New York, Lewis Publishers, p. 269-311.

Belitz, K., Hamlin, S.N., Burton, C.A., Kent, R.H., Fay, R.G., and Johnson, T.J., 2004, Water quality in the Santa Ana Basin, California, 1999-2001: U.S. Geological Survey Circular 1238, 38 p.

Bellar, T.A., Lichtenberg, J.J., and Kroner, R.C., 1974, The occurrence of organohalides in chlorinated drinking waters: Journal of the American Water Works Association, v. 66, no. 12 , p. 703-706.

Bender, D.A., Zogorski, J.S., Halde, M.J., and Rowe, B.L., 1999, Selection procedure and salient information for volatile organic compounds emphasized in the National Water-Quality Assessment Program: U.S. Geological Survey Open-File Report 99-182, 32 p.

Bertoldi, G.L., Johnston, R.H., and Evenson, K.D., 1991, Ground-water in the Central Valley, California-A summary report: U.S. Geological Survey Professional Paper 1401-A, 44 p. 
Burow, K.R., Panshin, S.Y., and Dubrovsky, N.M., Vanbrocklin, D., and Fogg, G.E., 1999, Evaluation of processes affecting 1,2-dibromo-3-chloropropane (DBCP) concentrations in ground water in the eastern San Joaquin Valley, California: Analysis of chemical data and groundwater flow and transport simulations: U.S. Geological Survey Water-Resources Investigation Report 99-4059, 57 p.

Burow, K.R., Shelton, J.L., and Dubrovsky, N.M., 1998, Occurrence of nitrate and pesticides in ground water beneath three agricultural land use settings in the eastern San Joaquin Valley, California, 1993-1995: U.S. Geological Survey Water-Resources Investigations Report 97-4284, $51 \mathrm{p}$.

Burow, K.R., Stork, S.V., and Dubrovsky, N.M., 1998, Nitrate and pesticides in ground water in the eastern San Joaquin Valley, California: Occurrence and trends: U.S. Geological Survey Water-Resources Investigations Report 98-4040-A, 33 p.

Burroughs, R.L., 1981, A summary of the geology of the San Luis Basin, Colorado-New Mexico, with emphasis on the geothermal potential for the Monte Vista Graben: Colorado Geological Survey Special Publication 17, 30 p.

California Department of Pesticide Regulation, 2003, Pesticide use data for 1991-2003 [digital data]: Sacramento, California Department of Pesticide Regulation.

Childress, C.J.O., Foreman, W.T., Conner, B.F., and Maloney, T.J., 1999, New reporting procedures based on long-term method detection levels and some considerations for interpretations of water-quality data provided by the U.S. Geological Survey National Water Quality Laboratory: U.S. Geological Survey Open-File Report 99-193, 19 p.

Covay, K.J., Banks, J.M., Bevans, H.E., and Watkins, S.A., 1996, Environmental and hydrologic settings of the Las Vegas Valley area and the Carson and Truckee River basins, Nevada and California: U.S. Geological Survey WaterResources Investigations Report 96-4087, 72 p.

Cozzarelli, I.M., and Baehr, A.L., 2003, Volatile fuel hydrocarbons and MTBE in the environment, in Holland, H.D., and Turekian, K.K., eds., Treatise on geochemistry: [Burlington, Mass.?], Elsevier, v. 9 of 10, p. 433-474.

Dawson, B.J., 2001, Ground-water quality in the southeastern Sacramento Valley aquifer, California, 1996: U.S. Geological Survey Water-Resources Investigations Report 01-4125, $24 \mathrm{p}$.
Domagalski, J.L., Dileanis, P.D., Knifong, D.L., Munday, C., May, J.T., Dawson, B.J., Shelton, J.L., and Alpers, C.N., 2000, Water-quality assessment of the Sacramento River Basin, California: Water-quality, sediment, and tissue chemistry, and biological data, 1995-1998: U.S. Geological Survey Open-File Report 00-319, accessed May 23, 2007, at http://ca.water.usgs.gov/sac nawqa/waterindex.html.

Domagalski, J.L., Knifong, D.L., Dileanis, P.D., Brown, L.R., May, J.T., Connor, V., and Alpers, C.N., 2000, Water quality in the Sacramento River Basin, California, 1994-98: U.S. Geological Survey Circular 1215, accessed May 23, 2007, at http://pubs.usgs.gov/circ/circ1215.

Domagalski, J.L., Knifong, D.L., MacCoy, D.E., Dileanis, P.D., Dawson, B.J., and Majewski, M.S., 1998, Water quality assessment of the Sacramento River Basin, California-Environmental setting and study design: U.S. Geological Survey Water-Resources Investigations Report 97-4254, $31 \mathrm{p}$.

Eckhardt, D.A.V., and Stackelberg, P.E., 1995, Relation of ground-water quality to land use on Long Island, New York: Ground Water, v. 33, no. 6, p. 1019-1033.

Edmonds, R.J., and Gellenbeck, D.J., 2002, Ground-water quality in the West Salt River Valley, Arizona, 1996-98Relations to hydrogeology, water use, and land use: U.S. Geological Survey Water-Resources Investigations Report 01-4126, 60 p.

Emery, P.A., Patten, E.P., Jr., and Moore, J.E., 1973, Analog model study of the hydrology of the San Luis Valley, southcentral Colorado: Colorado Water Conservation Board Ground-Water Circular 29, 21 p.

Extoxnet, 1993a, Pesticide information profile-Simazine: Extension Toxicology Network, accessed January 23, 2006, at http://pmep.cce.cornell.edu/profiles/extoxnet/pyrethrinsziram/simazine-ext.html.

Extoxnet, 1993b, Pesticide information profile-Atrazine: Extension Toxicology Network, accessed January 23, 2006, at http://pmep.cce.cornell.edu/profiles/extoxnet/24d-captan/ atrazine-ext.html.

Extoxnet, 1993c, Pesticide information profile-Diuron: Extension Toxicology Network, accessed January 23, 2006, at http://pmep.cce.cornell.edu/profiles/extoxnet/dienochlorglyphosate/diuron-ext.html.

Extoxnet, 1993d, Pesticide information profile-Tebuthiuron: Extension Toxicology Network, accessed January 23, 2006, at http://pmep.cce.cornell.edu/profiles/extoxnet/pyrethrinsziram/tebuthiuron-ext.html. 
Extoxnet, 1993e, Pesticide information profile-Carbofuran: Extension Toxicology Network, accessed April 5, 2006, at http://pmep.cce.cornell.edu/profiles/extoxnet/carbaryldicrotophos/carbofuran-ext.html.

Extoxnet, 1993f, Pesticide information profile-EPTC: Extension Toxicology Network, accessed April 5, 2006, at http://pmep.cce.cornell.edu/profiles/extoxnet/dienochlorglyphosate/eptc-ext.html.

Extoxnet, 1993g, Pesticide information profile-Bentazon: Extension Toxicology Network, accessed January 23, 2006, at http://pmep.cce.cornell.edu/profiles/extoxnet/24d-captan/ bentazon-ext.html.

Extoxnet, 1993h, Pesticide information profile-Metolachlor: Extension Toxicology Network, accessed January 23, 2006, at http://pmep.cce.cornell.edu/profiles/extoxnet/metirampropoxur/metolachlor-ext.html.

Extoxnet, 1993i, Pesticide information profile-Dinoseb: Extension Toxicology Network, accessed January 23, 2006, at http://pmep.cce.cornell.edu/profiles/extoxnet/dienochlorglyphosate/dinoseb-ext.html.

Gellenbeck, D.J., and Anning, D.W., 2002, Occurrence and distribution of pesticides and volatile organic compounds in ground water and surface water in Central Arizona Basins, 1996-1998, and their relation to land use: U.S. Geological Survey Water-Resources Investigations Report 01-4144, $107 \mathrm{p}$.

German Federal Ministry for Economic Cooperation and Development, 2007, Environmental handbookDocumentation on monitoring and evaluating environmental impacts, Compendium of environmental standards: German Federal Ministry for Economic Cooperation and Development, v. III, accessed June 18, 2007, at http://144.16.93.203/energy/HC270799/HDL/ENV/enven/ vol366.htm\#trichloroethene.

Gilliom, R.J., Alley, W.M., and Gurtz, M.E., 1995, Design of the National Water-Quality Assessment ProgramOccurrence and distribution of water-quality conditions: U.S. Geological Survey Circular 1112, 33 p.

Gilliom, R.J., Barbash, J.E., Crawford, C.G., Hamilton, P.A., Martin, J.D., Nakagaki, N., Nowell, L.H., Scott, J.C., Stackelberg, P.E., Thelin, G.P., and Wolock, D.M., 2006, The quality of our Nation's waters: Pesticides in the Nation's streams and ground water, 1992-2001: U.S. Geological Survey Circular 1291, 172 p.

Gronberg, J.M., Dubrovsky, N.M., Kratzer, C.R., Domagalski, J.L., Brown, L.R., and Burow, K.R., 1998, Environmental setting of the San Joaquin-Tulare Basins, California: U.S. Geological Survey Water-Resources Investigations Report 97-4205, 45 p.
Hamlin, S.N., Belitz, K., and Johnson, T., 2005, Occurrence and distribution of volatile organic compounds and pesticides in ground water in relation to hydrogeologic characteristics and land use in the Santa Ana Basin, Southern California: U.S. Geological Survey Scientific Investigations Report 2005-5032, 40 p.

Hamlin, S.N., Belitz, K., Kraja, S., and Dawson, B., 2002, Ground-water quality in the Santa Ana watershed, California-Overview and data summary: U.S. Geological Survey Water-Resources Investigations Report 02-4243, $137 \mathrm{p}$.

Hearne, G.A., and Dewey, J.D., 1988, Hydrologic analysis of the Rio Grande Basin north of Embudo, New Mexico, Colorado, and New Mexico: U.S. Geological Survey WaterResources Investigations Report 86-4113, 244 p.

Helley, E.J., and Harwood, D.S., 1985, Geologic map of the late Cenozoic deposits of the Sacramento Valley and northern Sierran foothills, California: U.S. Geological Survey Map MF-1790, 23 p., 5 sheets.

Hely, A.G., Mower, R.W., and Harr, C.A., 1971, Water resources of Salt Lake County, Utah: Utah Department of Natural Resources Technical Publication No. 31, 244 p.

Herndon, R.L., Brukner, D., and Sharp, G., 1997, Phase 1AGroundwater systems in the Orange County groundwater basin: Orange County Water District, California, 12 p.

Hirsch, R.M., Alley, W.M., Wilber, W.G., 1988, Concepts for a National Water-Quality Assessment Program: U.S. Geological Survey Circular 1021, 42 p.

Hitt, K.J., 1994, Refining 1970's land-use data with 1990 population data to indicate new residential development: U.S. Geological Survey Water-Resources Investigations Report 94-4250, 15 p.

Hosmer, D.W., and Lemeshow, S., 1989, Applied logistic regression: New York, John Wiley and Sons, Inc., 307 p.

Hull, L.C., 1984, Geochemistry of ground water in the Sacramento Valley, California: U.S. Geological Survey Professional Paper 91401-B, 36 p., 2 pls. in pocket.

Ivahnenko, T., and Barbash, J.E., 2004, Chloroform in the hydrologic system-Sources, transport, fate, occurrence, and effects on human health and aquatic organisms: U.S. Geologic Survey Scientific Investigations Report 20045137, 34 p.

Kilroy, K.C., Lawrence, S.J., Lico, M.S., Bevans, H.E., and Watkins, S.A., 1997, Water-quality assessment of the Las Vegas Valley area and the Carson and Truckee River basins, Nevada and California-Nutrients, pesticides, and suspended sediment, October 1969-April 1990: U.S. Geological Survey Water-Resources Investigations Report 97-4106, 144 p. 
King, W.E., Hawley, J.W., Taylor, A.M., and Wilson, R.P., 1971, Geology and ground-water resources of central and western Dona Ana County, New Mexico: Socorro, New Mexico Institute of Mining and Mineral Resources Hydrologic Report 1, 64 p.

Kohler, M.A., Nordenson, T.J., and Baker, D.R., 1959, Evaporation maps for the United States: Washington, D.C., U.S. Department of Commerce, Weather Bureau, Technical Paper no. 37, 13 p. and plates.

Kolpin, D.W., Barbash, J.E., and Gilliom, R.J., 2000, Pesticides in ground water of the United States, 1992-1996: Ground Water, v. 38, no. 6, p. 858-863.

Koterba, M.T., Wilde, F.D., and Lapham, W.W., 1995, Ground-water data-collection protocols and procedures for the National Water-Quality Assessment ProgramCollection and documentation of water-quality samples and related data: U.S. Geological Survey Open-File Report 95-399, $113 \mathrm{p}$.

Langmuir, D., 1997, Chapter 11: Oxidation-reduction concepts, in Aqueous environmental geochemistry: New Jersey, Prentice Hall, p. 403-430.

Larson, S.J., Gilliom, R.J., and Capel, P.D., 1999, Pesticides in streams of the United States - Initial results from the National Water-Quality Assessment Program: U.S. Geological Survey Water-Resources Investigations Report 98-4222, 92 p.

Lico, M.S., 1998, Quality of ground water beneath urban and agricultural lands in Las Vegas Valley and the Carson and Truckee River Basins, Nevada-Implications for water supply: U.S. Geological Survey Water-Resources Investigations Report 97-4259, 24 p.

Lopes, T.J., and Evetts, D.M., 2004, Ground-water pumpage and artificial recharge estimates for calendar year 2000 and average annual natural recharge and interbasin flow by hydrographic area, Nevada: U.S. Geological Survey Scientific Investigations Report 2004-5239, 82 p.

Maurer, D.K., and Thodal, C.E., 2000, Quantity and chemical quality of recharge, and updated water budgets, for the basin-fill aquifer in Eagle Valley, western Nevada: U.S. Geological Survey Water-Resources Investigations Report 99-4289, 46 p.

Miller, T., and Hamilton, P., 2001, Selected findings and current perspectives on urban and agricultural water quality by the National Water-Quality Assessment Program: U.S. Geological Survey Fact Sheet 047-01, 2 p.

Mueller, D.K., and Helsel, D.R., 1996, Nutrients in the Nation's waters-Too much of a good thing?: U.S. Geological Survey Circular 1136, 24 p.
National Oceanic and Atmospheric Agency (NOAA), 2006, National Weather Service, Comparative climatic data: National Climatic Data Service, accessed October 30, 2006, at http://www.ncdc.noaa.gov/oa/ncdc.html

Nevada Department of Agriculture, 2007, Nevada and its agriculture: Nevada Department of Agriculture, 19 p., accessed March 14, 2007, at http://agri.nv.gov/Brochures/ Nevada And Its Agriculture.pdf

Nevada State Demographer's Office, 2006, Nevada county population estimates July 1, 1990 to July 1, 2005-Includes cities and towns: Nevada State Demographer's Office, accessed October 5, 2006, at http://www.nsbdc.org/what/ data statistics/demographer/pubs/pop increase/pdfs/ NVpopul05.pdf.

Nolan, B.T., 2001, Relating nitrogen sources and aquifer susceptibility to nitrate in shallow ground waters of the United States: Ground Water, v. 39, no. 2, p. 290-299.

Page, R.W., 1986, Geology of the fresh ground-water basin of the Central Valley, California, with texture maps and sections: U.S. Geological Survey Professional Paper 1401C, 54 p., 5 pls in pocket.

Pesticide Action Network North America, 2006, Thiobencarb: Pesticide Action Network Pesticides Database, accessed April 6, 2006, at http://www.pesticideinfo.org/Detail Chemical.jsp?Rec Id=PC34584.

Pesticide Management Education Program, 1984a, Norflurazon: Herbicide Profile Fact Sheet Number 60, accessed January 23, 2006, at http://pmep.cce.cornell.edu/ profiles/herb-growthreg/naa-rimsulfuron/norflurazon/herbprof-norflurazon.html.

Pesticide Management Education Program, 1984b, 1,2dibromo-3-chloropropane (DBCP) chemical profile: Ithica, N.Y., Cornell University, accessed January 23, 2006, at http://pmep.cce.cornell.edu/profiles/fumigant/ dibromochloropropane/prof-dibromochloropropane.html

Planert, M., and Williams, J.S., 2000, Segment 1, California, Nevada, in Miller, J.A., ed., Ground water atlas of the United States: U.S. Geological Survey atlas, p. B1-B28.

Poland, J.F., and Lofgren, B.E., 1984, Case history 9.13, San Joaquin Valley, California, U.S.A., in Poland, J.F., ed., Guidebook to studies of land subsidence due to groundwater withdrawal: UNESCO Studies and Reports in Hydrology, no. 40, p. 263-277.

Powell, W.J., 1958, Ground-water resources of the San Luis Valley, Colorado: U.S. Geological Survey Water-Supply Paper 1379, 284 p.

Puckett, L.J., 1994, Nonpoint and point sources of nitrogen in major watersheds of the United States: U.S. Geological Survey Water-Resources Investigations Report 94-4001, 9 p. 
Rupert, M., 2003, Probability of detecting atrazine/desethylatrazine and elevated concentrations of nitrate in ground water in Colorado: U.S. Geological Survey WaterResources Investigations Report 02-4269, 35 p.

Russell, H.H., Matthews, J.E., and Sewell, G.W., 1992, TCE removal from contaminated soil and ground water: U.S. Environmental Protection Agency, EPA/540/S-92/002, 10 p.

Seiler, R.L., Stollenwerk, K.G., and Garbarino, J.R., 2005, Factors controlling tungsten concentrations in ground water, Carson Desert, Nevada: Applied Geochemistry, v. 20. p. 423-441.

Shelton, J.L., 2005, Assessment of shallow ground-water quality in recently urbanized areas of Sacramento, California, 1998: U.S. Geological Survey Scientific Investigations Report 2005-5148, 81 p., accessed May 23, 2007, at http://pubs.usgs.gov/sir/2006/5148/.

Shipley, D.O., and Rosen, M.R., 2005, Identification of nitrate and dissolved-solids sources in ground water by GIS analyses: Environmental Practice, v. 7, no. 1, p. 32-43.

Solley, W.B., Pierce, R.R., and Perlman, H., 1998a, U.S. Geological Survey National water-use data files: California 1995 watershed data file, accessed November 8, 2006, at http://water.usgs.gov/watuse/spread95.html.

Solley, W.B., Pierce, R.R., and Perlman, H.A, 1998b, Estimated use of water in the United States in 1995: U.S. Geological Survey Circular 1200, 71 p.

Spectrum Laboratories, Inc., 2006, Chemical fact sheet: Chemical abstract number 75694, accessed August 6, 2006, at http://www.speclab.com/compound/c75694.htm.

Squillace, P.J., Moran, M.J., Lapham, W.W., Price, C.V., Clawges, R.M., and Zogorski, J.S., 1999, Volatile organic compounds in untreated ambient groundwater of the United States, 1985-1995: Environmental Science and Technology, v. 33 , p. $4176-4187$.

Squillace, P.J., Moran, M.J., and Price, C.V., 2004, VOCs in shallow groundwater in new residential/commercial areas of the United States: Environmental Science and Technology, v. 28, p. 5327-5338.

Squillace, P.J., Zorgorski, J.S., Wilber, W.G., and Price, C.V., 1996, Preliminary assessment of the occurrence and possible sources of MTBE in groundwater in the United States, 1993-1994: Environmental Science and Technology, v. 30 , no. 5 , p. $1721-1730$.

Steinberg, D., and Colla, P., 2004, Logistic regression, Chapter 5 in SYSTAT II, Statistics II: Richmond, Calif., SYSTAT Software, Inc., p. II-207-II-278.
Stevenson, J.C., Staver, K., and Brinsfield, R., 1986, Surface runoff and groundwater impacts from agricultural activities in the Chesapeake region, in Summers, J.B., and Anderson, S.S., eds., U.S. Committee on Irrigation and Drainage: Proceedings, Toxic Substances in Agricultural Water Supply and Drainage, Defining the Problems, p. 211-219.

SYSTAT Software Inc., 2004, SYSTAT 11, Statistics I, Software documentation: Richmond, Calif., SYSTAT Software Inc., 493 p.

Tesoriero, A.J., and Voss, F.D., 1997, Predicting the probability of elevated nitrate concentrations in the Puget Sound Basin-Implications for aquifer susceptibility and vulnerability: Ground Water, v. 35, no. 6, p. 1029-1039.

Thelin, Gail, 2005a, 1992 county pesticide use estimates for 220 compounds, ver. 2.0: U.S. Geological Survey data available on the Web, accessed October 6, 2005, at http:// water.usgs.gov/GIS/metadata/usgswrd/XML/pesticide use92.xml.

Thelin, Gail, 2005b, 1997 county pesticide use estimates for 220 compounds, ver. 2.0: U.S. Geological Survey data available on the Web, accessed October 6, 2005, at http:// water.usgs.gov/GIS/metadata/usgswrd/XML/pesticide use97.xml.

Thiros, S.A., 2003a, Quality and sources of shallow ground water in areas of recent residential development in Salt Lake Valley, Salt Lake County, Utah: U.S. Geological Survey Water-Resources Investigations Report 03-4028, 74 p.

Thiros, S.A., 2003b, Hydrogeology of shallow basinfill deposits in areas of Salt Lake Valley, Salt Lake County, Utah: U.S. Geological Survey Water-Resources Investigations Report 03-4029, 23 p.

Thiros, S.A., and Manning, A.H., 2004, Quality and sources of ground water used for public supply in Salt Lake Valley, Salt Lake County, Utah, 2001: U.S. Geological Survey Water-Resources Investigations Report 03-4325, 95 p.

Thorn, C.R., McAda, D.P., and Kernodle, J.M., 1993, Geohydrologic framework and hydrologic conditions in the Albuquerque Basin, central New Mexico: U.S. Geological Survey Water Resources-Investigations Report 93-4149, $106 \mathrm{p}$.

Toxic Use Reduction Institute, 2007, Five chemicals study: Lowell, Mass., University of Massachusetts, p. 5-2-5-70, accessed June 18, 2007, at http://www.turi.org/library/turi publications/five chemicals study.

U.S. Census Bureau, 2005, Census 2000, 1990 Census: U.S. Census Bureau, accessed August 18, 2005, at http:// quickfacts.census.gov/qfd/states/06/0603526.html. 
U.S. Department of Agriculture, 1994, State Soil Geographic (STATSGO) Data Base, Data use information: Fort Worth, Tex., U.S. Department of Agriculture, Miscellaneous Publication Number 1492, 35 p.

U.S. Environmental Protection Agency, 2006a, Ground water and drinking water-List of Drinking Water Contaminants and MCLs: U.S. Environmental Protection Agency, accessed March 28, 2006, at http://www.epa.gov/safewater/ contaminants/index.html\#dbps.

U.S. Environmental Protection Agency, 2006b, Ground water and drinking water-Consumer fact sheet on: dibromochloropropane: U.S. Environmental Protection Agency, accessed January 24, 2006, at http://www.epa.gov/ safewater/contaminants/dw contamfs/dibromoc.html.

U.S. Geological Survey, 1999, The quality of our Nation's waters-nutrients and pesticides: U.S. Geological Survey Circular 1225, 82 p.

Vogel, T.M., and McCarty, P.L., 1985, Biotransformation of tetrachloroethylene to trichloroethylene, dichloroehtylene, vinyl chloride, and carbon dioxide under methanogenic conditions: Applied and Environmental Microbiology, v. 49, no. 5 , p. 1080-1083.
Walvoord, M.A., Phillips, F.M., Stonestrom, D.A., Evans, R.D., Hartsough, P.C., Newman, B.D., and Striegl, R.G., 2003, A reservoir of nitrate beneath desert soils: Science, v. 302, p. 1021-1024.

Welch, A.H., 1994, Ground-water quality and geochemistry in Carson and Eagle Valleys, Western Nevada and Eastern California: U.S. Geological Survey Open-File Report 93-33, $99 \mathrm{p}$.

Williamson, A.K., Prudic, D.E., and Swain, L.A., 1989, Ground-water flow in the Central Valley, California: U.S. Geological Survey Professional Paper 1401-D, 127 p.

Zogorski, J.S., Carter, J.M., Ivahnenko, T., Lapham, W.W., Moran, M.J., Rowe, B.L., Squillace, P.J., and Toccalino, P.L., 2006, The quality of our Nation's waters_-Volatile organic compounds in the Nation's ground water and drinking-water supply wells: U.S. Geological Survey Circular 1292, 101 p. 
This page is intentionally left blank. 


\section{Appendixes}

Data files are presented in four Microsof $\mathrm{t}^{\circledR}$ Excel workbooks. The appendixes can be accessed and downloaded at URL http://pubs.usgs.gov/sir/2007/5179.

Appendix A. Pesticide concentrations in shallow ground-water samples collected from agricultural and urban areas within regional National Water-Quality Assessment Program study units in the arid to semiarid Western United States, 1993-2004.

Appendix B. Volatile organic compound concentrations in shallow ground-water samples collected from agricultural and urban areas within regional National Water-Quality Assessment Program study units in the arid to semiarid Western United States, $1993-2004$.

Appendix C. Nutrient concentration in shallow ground-water samples collected from agricultural and urban areas within regional National Water-Quality Assessment Program study units in the arid to semiarid Western United States, $1993-2004$.

Appendix D. Ancillary data for shallow agricultural wells from which samples were collected in agricultural and urban areas within regional National Water-Quality Assessment Program study units in the arid to semiarid Western United States, $1993-2004$. 
This page is intentionally left blank. 
For more information contact:

Director, Nevada Water Science Center

U.S. Geological Survey

2730 N. Deer Run Road

Carson City, Nevada 89701

http://nevada.usgs.gov 


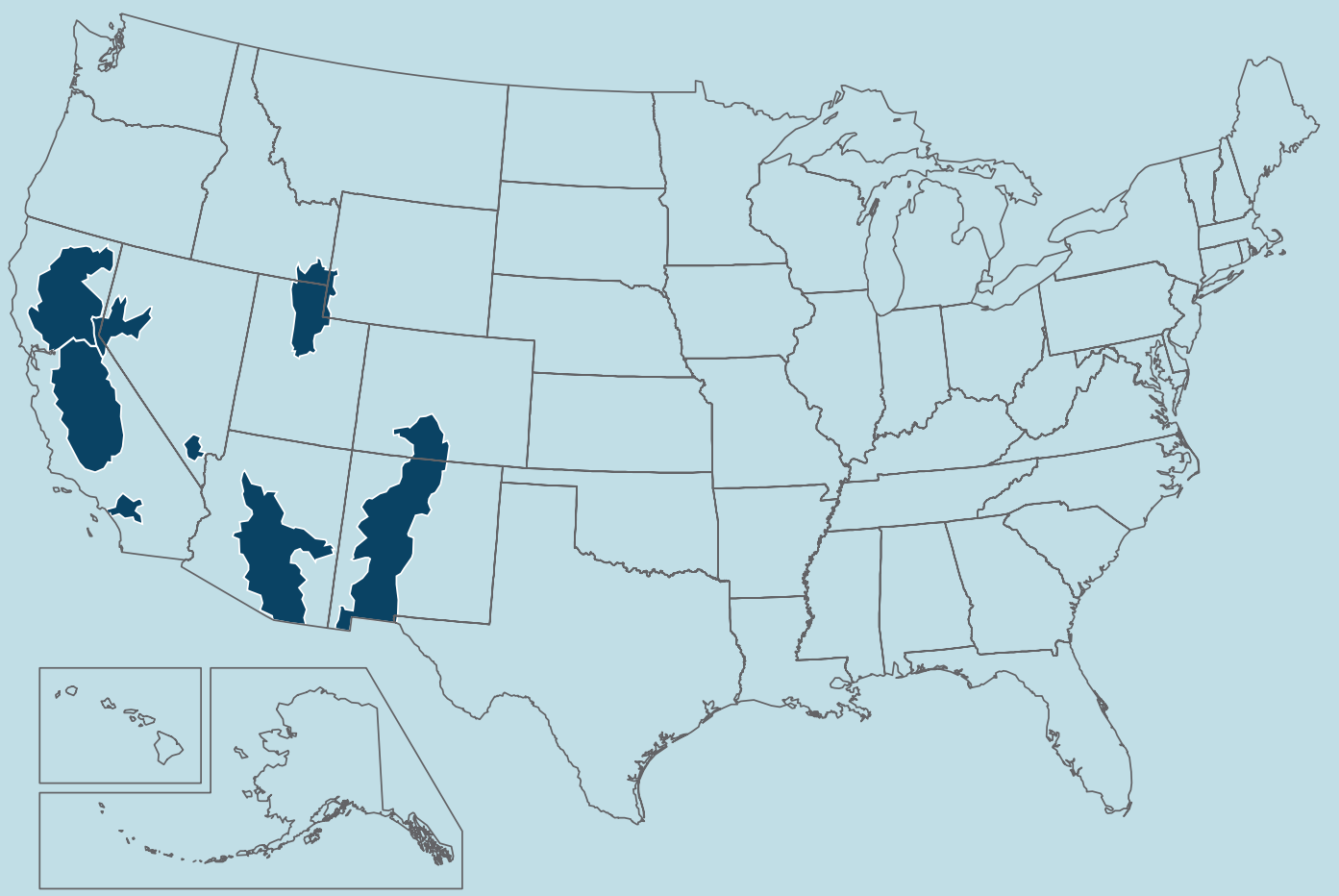

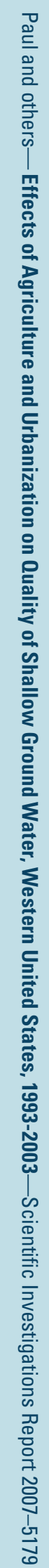

